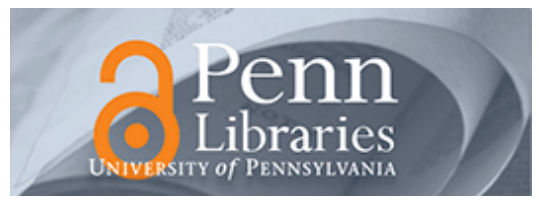

University of Pennsylvania

ScholarlyCommons

Health Care Management Papers

Wharton Faculty Research

2-2017

\title{
Antitrust Treatment of Nonprofits: Should Hospitals Receive Special Care?
}

\author{
Cory Capps \\ Bates White LLC \\ Dennis W. Carlton \\ University of Chicago \\ Guy David \\ University of Pennsylvania
}

Follow this and additional works at: https://repository.upenn.edu/hcmg_papers

Part of the Antitrust and Trade Regulation Commons, Health and Medical Administration Commons, Nonprofit Administration and Management Commons, and the Nonprofit Organizations Law Commons

\section{Recommended Citation}

Capps, C., Carlton, D. W., \& David, G. (2017). Antitrust Treatment of Nonprofits: Should Hospitals Receive Special Care?. National Bureau of Economic Research Working Paper Series, http://dx.doi.org/10.3386/ w23131

This is a working paper, not accepted for publication or review.

This paper is posted at ScholarlyCommons. https://repository.upenn.edu/hcmg_papers/12

For more information, please contact repository@pobox.upenn.edu. 


\title{
Antitrust Treatment of Nonprofits: Should Hospitals Receive Special Care?
}

\begin{abstract}
Nonprofit hospitals receive favorable tax treatment in exchange for providing socially beneficial activities. Extending this rationale would suggest that, insofar as suppression of competition would allow nonprofits to cross-subsidize care for needy populations, nonprofit hospital mergers should be evaluated differently than mergers of for-profit hospitals. However, this rationale rests upon the premise that nonprofit hospitals with greater market power provide more care to the needy. In this paper, we develop a theoretical model showing that the welfare implications of an antitrust policy that favors nonprofit hospitals depends on the link between market power and charity care provision. To test the link, we use three measures of charity care-two dollar-denominated and one based on service volume-to study charity care provision by for-profit and non-profit hospitals under different competition conditions. Using detailed California data from 2001 to 2011, we find no evidence that nonprofit hospitals are more likely than for-profit hospitals to provide more charity care, or to offer more unprofitable services, when competition falls. Overall, while some courts have given deference to defendants' nonprofit status, our study finds no empirical evidence that such hospitals provide greater charity care as they have greater market power.
\end{abstract}

\section{Disciplines}

Antitrust and Trade Regulation | Health and Medical Administration | Nonprofit Administration and Management | Nonprofit Organizations Law

\section{Comments}

This is a working paper, not accepted for publication or review. 
NBER WORKING PAPER SERIES

\author{
ANTITRUST TREATMENT OF NONPROFITS: \\ SHOULD HOSPITALS RECEIVE SPECIAL CARE? \\ Cory Capps \\ Dennis W. Carlton \\ Guy David \\ Working Paper 23131 \\ http://www.nber.org/papers/w23131
NATIONAL BUREAU OF ECONOMIC RESEARCH
1050 Massachusetts Avenue
Cambridge, MA 02138
February 2017

We thank Bob Town, Marty Gaynor, Tomas Philipson, Mark Pauly and participants at the NBER Health Care Program for helpful comments and suggestions on an earlier draft and to Samantha Burn and Karen Zhang for excellent research assistance. The views expressed herein are those of the authors and do not necessarily reflect the views of the National Bureau of Economic Research.

NBER working papers are circulated for discussion and comment purposes. They have not been peer-reviewed or been subject to the review by the NBER Board of Directors that accompanies official NBER publications.

(C) 2017 by Cory Capps, Dennis W. Carlton, and Guy David. All rights reserved. Short sections of text, not to exceed two paragraphs, may be quoted without explicit permission provided that full credit, including $\odot$ notice, is given to the source. 
Antitrust Treatment of Nonprofits: Should Hospitals Receive Special Care?

Cory Capps, Dennis W. Carlton, and Guy David

NBER Working Paper No. 23131

February 2017

JEL No. I11,L22,L31

\begin{abstract}
$\underline{\text { ABSTRACT }}$
Nonprofit hospitals receive favorable tax treatment in exchange for providing socially beneficial activities. Extending this rationale would suggest that, insofar as suppression of competition would allow nonprofits to cross-subsidize care for needy populations, nonprofit hospital mergers should be evaluated differently than mergers of for-profit hospitals. However, this rationale rests upon the premise that nonprofit hospitals with greater market power provide more care to the needy. In this paper, we develop a theoretical model showing that the welfare implications of an antitrust policy that favors nonprofit hospitals depends on the link between market power and charity care provision. To test the link, we use three measures of charity care-two dollardenominated and one based on service volume - to study charity care provision by for-profit and non-profit hospitals under different competition conditions. Using detailed California data from 2001 to 2011, we find no evidence that nonprofit hospitals are more likely than for-profit hospitals to provide more charity care, or to offer more unprofitable services, when competition falls. Overall, while some courts have given deference to defendants' nonprofit status, our study finds no empirical evidence that such hospitals provide greater charity care as they have greater market power.
\end{abstract}

Cory Capps

Bates White LLC.

1300 Eye Street, NW

Suite 600

Washington, DC 20005

cory.capps@bateswhite.com

Dennis W. Carlton

Booth School of Business

University of Chicago

5807 S. Woodlawn Ave.

Chicago, IL 60637

and NBER

dennis.carlton@chicagobooth.edu
Guy David

The Wharton School

University of Pennsylvania

202 Colonial Penn Center

3641 Locust Walk

Philadelphia, PA 19104-6218

and NBER

gdavid2@wharton.upenn.edu 


\section{Introduction}

Private nonprofit hospitals account for $58 \%$ of all short-term, non-federal, general hospitals, with private for-profit hospitals accounting for $21 \%$ and government hospitals for $21 \%{ }^{1}$. Hospitals are designated as nonprofit if they do not distribute profits and are deemed to provide sufficient public benefits such as charity care. In exchange, nonprofit hospitals receive financial benefits, including exemptions from federal income taxes and state property taxes. In contrast, under the antitrust laws, nonprofit hospitals typically do not receive an analogous concession in recognition of their provision of public benefits, although some courts in older cases used nonprofit status as a basis for lenient antitrust treatment Most commonly, actions by nonprofit hospitals that would increase market power, such as mergers, joint ventures, collective price setting, or other conduct such as tie-in sales, are precluded because increased market power is presumed to harm consumers by elevating price and reducing output. But, if nonprofit hospitals use their profits to provide public benefits, should a nonprofit hospital be able to defend itself against an antitrust claim by arguing that any increased market power it achieves will enable it to increase its provision of public benefits, even if the prices to some patients rise? As noted, the tax laws do provide favorable treatment. Should the antitrust laws, or courts in antitrust cases, do the same?

Putting aside the practically unlikely first-best solution of direct funding of care to the needy through lump sum taxes and focusing on second-best solutions, theory is ambiguous. ${ }^{2}$ For

\footnotetext{
American Hospital Association, Fast Fact on US Hospitals, January 2014.

2 Under the Affordable Care Act, not all states expanded Medicaid and, even in those did, uninsurance rates remained at
} 
example, Philipson and Posner (2009) develop a model in which nonprofits maximize a combination of profits and output. They show that a nonprofit with this objective function will set a lower price than would a for-profit firm. However, they also show that the price effects of an increase in market power will be greater for nonprofits. Based on this result, they argue against special antitrust consideration for nonprofits. In contrast to their findings, we present a model below in which, by relaxing the financing constraint, competitionreducing mergers of nonprofits can increase total welfare by increasing the provision of charity care. In this case, the antitrust laws should not necessarily condemn competitionreducing mergers of nonprofit hospitals without an empirical examination.

Overall, economic theory indicates that a balancing of social benefits against harm from market power may be appropriate under the assumption that nonprofits will provide greater social benefits when they have greater market power. In this paper, we go beyond theory and evaluate whether there is systematic empirical evidence that nonprofit hospitals do in fact increase their provision of uncompensated care to those without insurance-the main public benefit often claimed by nonprofits - in response to increased market power. Few papers in the empirical literature address this question generally and, to our knowledge, no paper studies the effect of changes in market power on the volume of uncompensated care rendered by nonprofit hospitals. This most closely related study is Garmon (2009), which examines the relationship between competition and the estimated dollar value of charity care provided. ${ }^{3}$

4\% or higher. Kaiser Family Foundation, State Health Facts, "Health Insurance Coverage of the Total Population: 2015," available at http://kff.org/other/state-indicator/total-population/. At present, uninsurance rates are unlikely to decline further and may increase.

3 We discuss Garmon in more detail below; as we also show below, measuring the volume of uncompensated care 
Using 11 years of detailed data on hospital competition and several measures of charity care, we find no empirical evidence that nonprofit hospitals increase charity care as they acquire greater ability to do so through increased market power. We confirm our baseline econometric results with a second, independent analysis of market power based on how the travel times of patients change in response to changes in market power. Hospitals in litigated merger cases have appealed to their nonprofit status as part of their defense, and with success in some cases. Our results, however, show no significant difference in the propensities of nonprofit and for-profit hospitals to provide more charity care as they have greater market power. That is, we find no empirical basis for courts in merger cases to treat nonprofit hospitals more favorably on the grounds that they may use their market power to provide greater charity care.

We also find that, after controlling for their size, nonprofit hospitals provide only marginally more uncompensated care than do for-profit hospitals. This finding, together with our central result, is consistent with other studies of for-profit and nonprofit hospitals that have found little difference in how the two organizational forms respond to financial incentives. It is beyond the scope of this paper to question the grounds for tax exemption, but our evidence suggests a potential role for enhanced administrative oversight of nonprofit hospitals.

Moreover, we find that controlling for size, government-run hospitals, rather than nonprofit hospitals, provide a disproportionately high amount of uncompensated care. ${ }^{4}$ This result

directly can generate different results than measuring the volume of uncompensated care.

4 However, beyond their compelling community orientation, non-federal government hospitals have been found to be less efficient compared to private ones (Douglas, Currie, and Simeonova 2010). 
raises the important question of whether tax exemptions for nonprofit hospitals are a less efficient method of funding care for the poor than providing an equivalent amount of funding to government run hospitals. Indeed, multiple government entities have started examining whether the public benefits of specific nonprofit hospitals justify the tax benefits they receive and in some cases have rescinded the nonprofit status of the hospital. ${ }^{5}$

This paper is organized as follows. In section II we provide background on the application of the antitrust laws to nonprofit firms such as hospitals and the justifications for nonprofit status. We also discuss the theoretical and empirical literature on differences in behavior between nonprofit and for-profit hospitals. In section III we develop a theoretical model of the effects of competition on the behavior of nonprofit hospitals. We show that the provision of public benefits such as uncompensated care can indeed rise when nonprofit hospitals increase their market power and therefore, from the viewpoint of theory, it may be perfectly legitimate to allow nonprofits to argue that an increase in their market power would benefit society by increasing the provision of uncompensated care. In section IV, we test empirically the theoretical proposition that increased market power leads to an increase in public benefits using

5 For example, in 2010 the Illinois Supreme Court ruled that Provena Covenant Medical Center in Urbana, Illinois did not meet the requirements for tax exemption. The court noted that the hospital waived just $0.7 \%$ of its revenue, far less than the tax benefits it stood to receive. The court also cited Provena's small charity pool: only 302 of the hospital's 10,000 inpatient and 100,000 outpatient admissions involved charitable care (Sataline, 2010). Separately, Senator Grassley and colleagues have introduced federal legislation that would impose penalties on nonprofit hospitals that do not meet a minimum requirement for uncompensated care provision ("Grassley Targets Nonprofit Hospitals on Charity Care," Wall Street Journal, December 18, 2008). Controversy over the public benefits provided by nonprofit hospitals have continued even after the introduction of new community benefits reporting requirements under the Affordable Care Act. (Advisory Board, 2013; Doyle, 2014; Schencker, 2015). 
data from California hospitals from 2001 to 2011 and find no evidence to support that theory. Section V concludes the paper.

\section{Background}

The rationale underlying nonprofit status is that such firms presumably provide some public benefits that for-profit firms would have little or no incentive to provide. Implicit in this rationale is the notion that financing such benefits through tax exemptions is either more efficient or more politically feasible than financing through direct subsidy. The provision of those benefits could depend on a suppression of competition. For example, two food organizations might agree to divide a city in half and serve separate halves in order to economize on resources rather than "compete" with each other to serve meals throughout the city. The antitrust laws would generally condemn such market allocation among for-profit firms as a violation of the antitrust laws that prohibit conspiracy.

However, in several litigated cases, courts have allowed nonprofits to defend behavior that would otherwise violate the antitrust laws with the argument that the public benefits of the challenged behavior outweigh the adverse effects of lessened competition. For example, in the MIT case, the Department of Justice sued several universities because they entered an agreement to restrict competition for students through financial aid. ${ }^{6}$ Although the district court found the agreement a per se violation of the antitrust laws, the appellate court reversed the decision and ordered the district court to take explicit account of the claimed public

$6 \quad$ See Carlton et al. (1995) for an economic analysis of this case, U.S. v. Brown University, et al., 5F.3d 658 (3 ${ }^{\text {rd }}$ Cir. 1993) (Carlton served as an expert on behalf of MIT). 
benefit of the collective action (spreading a given amount of aid among more rather than fewer poor students) as an offset to any harm from the collective agreement. ${ }^{7}$

Nonprofit status has also been an issue in multiple hospital merger cases, with merging nonprofit hospitals consistently raising their status as a defense (Richman, 2007). Courts have varied in their receptiveness. The most extreme case was the merger of the two largest hospitals in Grand Rapids, Michigan, Butterworth Hospital and Blodgett Memorial Medical Center. There, the district court held that the Federal Trade Commission (FTC) had established its prima facie case that the merger would lessen competition. Nevertheless, relying on the hospitals' nonprofit status, the court denied the FTC's motion for an order to block the merger. ${ }^{8}$ In this case, the court's logic differed from the rationale described in this paper: rather than balancing harm from market power against the value of community benefits (funded by that same market power), the court concluded that, because of its nonprofit status, the merged system would not raise prices in the first place, despite the presumed ability to do so. Similarly, in a case in Joplin, Missouri, the court cited the merging hospitals' nonprofit status as one of several reasons why it rejected the FTC's merger challenge. ${ }^{9}$

7 In antitrust parlance, a per se violation is one where the conduct is deemed so likely to reduce output that no analysis of the reasonableness of the conduct is allowed, while under a rule of reason a defendant is allowed to justify the reasonableness of his behavior through a comparison of costs and benefits. The antitrust issue for nonprofits is whether they are allowed to use a rule of reason defense and include expanded public benefits as part of the justification for their behavior.

$8 \quad$ FTC v. Butterworth Health, 946 F. Supp. 1285 (W.D. Mich. 1996).

$9 \quad$ FTC v. Freeman Hospital, 911 F. Supp. 1213 (W.D. Mo. 1995), aff'd, 69 F.3d 260 (8th Cir. 1995). The court in United States v. Carilion Health System articulated a similar view. 707 F. Supp. 840 (W.D. Va. 1989), aff'd, 892 F.2d 1042 (4th Cir. 1989) (unpublished table decision). 
Thus, there are two possible rationales for more lenient antitrust treatment of nonprofit hospitals. The first, which courts have primarily focused on to date, is that nonprofit hospitals would not exercise any market power they might gain. The second is that they will do so, but in ways that are socially valuable-for example, use their enhanced market power to raise the level of uncompensated care. The first rationale has been studied and, with the exception of Lynk (1995), rejected. Studies have found that nonprofits do charge higher prices in more concentrated markets (Simpson and Shin 1998; Dranove and Ludwick 1999; Keeler et al. 1999). Moreover, a number of case studies of nonprofit hospital mergers have found that nonprofit hospitals increase price when they gain market power through merger (Vita and Sacher, 2001; Krishnan, 2001; Haas-Wilson and Garmon, 2011; Thompson, 2011; Tenn, 2011)..$^{10}$

As for the second rationale, the economic literature has not made comparable progress in addressing whether and how the provision of public benefits changes as a result of increased market power - the focus of this paper. ${ }^{11}$ After all, the public benefits have to be paid for somehow, and as we discuss next, higher prices to some patients is a potential mechanism to

10 Each study finds evidence of post-merger price increases; however, for the merger studied in Thompson (2011), prices went up for two insurers, down for a third, and remained about the same for the fourth.

11 Tax exemptions and financing through tax exempt bonds for nonprofits are (or used to be) justified by a "bargain" that was "struck between the hospital and the community: a hospital would treat patients who were unable to pay, and the government would grant a tax exemption to the hospital” (Pellegrini, 1989). Originally the IRS code defined charity as "relief to the poor," but, after the introduction of Medicare and Medicaid, with the bulk of hospital revenue coming from private insurance and public programs, the hospital industry pushed the IRS to revise its definition of "charitable services" (Seaton and Koob, 2009). Under current federal requirements, nonprofit hospitals are expected to provide "community benefits" in return for their 501(c)(3) tax-exempt status. While the definition of "community benefits" is broader (Nicholson et. al., 2000), the provision of charity care in the form of free or reduced price services remains at the heart of the justification for nonprofit hospital tax exemptions. 
finance them. Although the effects of competition on nonprofit hospitals' provision of charity care have not been closely studied, some literature examines whether nonprofit hospitals differ in their behavior from for-profit hospitals and specifically with regard to the provision of “community benefits” (e.g. Duggan, 2000, 2002). This literature generally shows that nonprofits and for-profits respond similarly to financial incentives and, in at least one case, do not differ in how they spend incremental funds on charity care. ${ }^{12}$ If there is in fact no difference in the provision of public benefits, the entire rationale for special tax treatment for nonprofits is suspect. There is also evidence that hospitals rely on cross-subsidies for the provision of unprofitable services (David et al., 2014). However, the studies in this literature typically do not control for the competitive environment and therefore do not look at whether any differential behavior towards the provision of charity care between nonprofit and forprofit hospitals depends on market power. ${ }^{13}$

We have found only one study that empirically examines the effect of hospital competition on the provision of public benefits by nonprofit hospitals, Garmon (2009). Using data from Texas and Florida for 1999-2002, Garmon analyzes the effects of changes in competition on the dollar value of charity, measured as a hospital's cost-to-charge ratio times the sum of its charity care and bad debt. Garmon also examines the effect of changes in competition on hospitals’ average revenue from uninsured patients. He concludes that competition and

12 Sloan (2001) finds that nonprofits and for-profits provide a similar quality of care but that for-profits cost Medicare more, ceteris paribus. Because Medicare prices are regulated, this suggests that for-profit hospitals order more costly procedures for paying patients than nonprofit hospitals.

13 For example, Stensland, Gaumer, and Miller (2010) find that hospitals that face less competition and have greater private payer revenue tend to have higher costs, which can create a misleading impression that private payer profits subsidize unprofitable care provided to government-insured patients. 
charity care are "if anything, positively related.” That is, Garmon finds no evidence in support of more favorable antitrust treatment for nonprofit hospitals.

Our study explores a more direct, volume-based measure of inpatient uncompensated care that is unlikely to be affected by differences in accounting practices across hospitals. As we demonstrate, dollar-denominated measures of charity or uncompensated care have been subject to rapid list price inflation and may be a poor representation of hospitals' ability to translate their surplus into provision of unprofitable services. We also examine whether nonprofit hospitals expend their rents in a socially beneficial way by maintaining unprofitable service lines, a practice that benefits all patients, not just charity care patients. Finally, we examine 11 years of data, allowing us to capture greater variability and leverage changes in hospitals' market power and ownership status. This in turn allows us to rely on the panel aspects of our data as opposed to relying primarily on cross-sectional variation.

\section{Models of nonprofit objectives and constraints}

Philipson and Posner (2009), develop a theory in which altruistic nonprofit producers exhibit some degree of "output preferences;” that is, they derive utility directly from output in addition to profits. They recognize the difference between a nonprofit's utility and the utility in the absence of altruism, but show that, nevertheless, competition still maximizes society's surplus. Based on that model, Philipson and Posner recommend an antitrust doctrine that does not distinguish between for-profit and nonprofit actors. We show that their result 
vanishes when nonprofits have a slightly more general objective function than the one postulated in their paper.

The key insight that Philipson and Posner identify is that if an altruist has an output preference, then competition among altruists, just like competition among profit-maximizing firms, will generate the "correct” marginal pricing conditions, but only if the social welfare function values consumption in the same way as the altruist. For example, if $\alpha$ represents the additional value that the altruist attaches to everyone's incremental health consumption, then $p=c-\alpha$ is the optimal pricing condition, where $p$ is the price and $c$ is marginal cost. But for this pricing condition to represent optimality, it must also be the case that such marginal pricing will lead to financial viability for the firm. However, even in the simplest constant returns to scale model, this cannot be true unless the altruist has funding sufficient to subsidize the consumption of the poor (a "rich altruist"), as Philipson and Posner assume. Conversely, if funds must come from the revenue of the nonprofit firm rather than from the rich altruist, then it must be the case that the financing constraint will matter. ${ }^{14}$ Therefore, the ability to exercise market power is critical ingredient the ability to provide uncompensated care, an ingredient completely missing from the Philipson and Posner analysis.

In addition, the altruist in the Philipson and Posner model values the incremental health care consumption of all consumers at $\alpha$. A slight modification is to allow the altruist to value the health care consumption of different individuals differently. For illustration, suppose that the altruist thinks that rich people can afford a minimal level of health care consumption, but

14 In essence, we do not allow the altruist to levy lump sum taxes on the public. 
poor people cannot. Hence, the altruist values additional health care consumption (beyond the minimum) of rich people at zero and that of poor people (who are below the minimum) at $\alpha .{ }^{15}$ These two changes to the Philipson and Posner model—incorporating a financing constraint and allowing the altruist to differentially value the health consumption of the rich and the poor—can completely reverse their conclusion.

Our point is not that our assumptions are necessarily superior to theirs but rather that their strong theoretical conclusion does not survive even minor changes to their model's assumptions. Given the sensitivity of the theoretical conclusions to the assumptions, only an empirical analysis can resolve the issue of the proper role of nonprofit status in antitrust analysis.

Two implications follow from our modifications. First, if the financing constraint matters (as would be the case if the altruist is not the sole source of funds), then the creation of market power through merger, through collective action such as coordinated price setting, or through conduct such as tie in sales may benefit society because the elimination of competition relaxes the financing constraint. Second, in order for market power to be exercised so as to generate funds to subsidize uncompensated care, the nonprofit firm must be able to charge differential prices to the rich and the poor. ${ }^{16}$ Without this ability, the transfer from the rich to the poor could not occur. But competition makes such price discrimination difficult: with

15 By and large, the need to access charity care is discrete (patients either have insurance or they do not). Our assumption can easily be relaxed and our results continue to apply as long as the altruist places a higher marginal value on health care consumption by the poor than the rich.

16 While many of the uninsured are not poor, for simplicity, we use the terms "rich" and "poor" to denote the patients that are paying above competitive rates and the patients who are benefitting from cross-subsidization. 
differential pricing, hospitals (even nonprofits) will want to poach their rivals' profitable customers and this erodes the ability to exercise market power. Hence, competition-reducing mergers can allow the merged firm to use its extra profits to subsidize the provision of public benefits, such as uncompensated care. We now briefly describe the model and refer the reader to Appendix A for a fuller discussion.

Suppose the altruist values additional health consumption of the poor, $q_{2}$, at $\alpha$, and that the cost function of a hospital that provides $q_{1}$ care to the rich and $q_{2}$ to the poor is given by $c\left(q_{1}, q_{2}\right)=F+c \cdot\left(q_{1}+q_{2}\right)$ where $c$ is the marginal cost of health care and $F$ is a fixed cost. Assuming for simplicity that there are two hospitals owned by altruists, Bertrand competition will produce the equilibrium $p_{1}=c-\alpha$ and $p_{2}=c$. But this equilibrium produces losses for each firm and so is not sustainable unless each altruist has a pool of wealth that it can use to subsidize health care. If we abandon the Philipson-Posner assumption that the altruist can finance losses with lump sum transfers, then profits must be nonnegative, and we see that Bertrand competition with two firms is not possible. Competition prevents the firms from earning enough money to subsidize care for the poor. ${ }^{17}$

Suppose now that the two firms merge or form a cartel and thereby eliminate competition. Since the firm is still altruistic, it follows that it can use its market power to raise price above $c$ for the rich and thereby afford to lower the price below $c$ for the poor. In fact, if the altruist

17 With less vigorous forms of competition, such as Cournot, charity care may be provided but not in the optimal amount. See Appendix A. 
seeks to maximize consumer surplus (reflecting the altruist's extra marginal valuation of health consumption by the poor) then the altruist will choose $p_{1}$ and $p_{2}$ to maximize

$$
\begin{aligned}
& \underset{p_{1}, p_{2}}{\operatorname{Max}} \int_{0}^{q_{1}\left(p_{1}\right)}\left[p_{1}(x)-c\right] d x+\int_{0}^{q_{2}\left(p_{2}\right)}\left[p_{2}(x)-c+\alpha\right] d x \\
& \text { s.t. } \quad p_{1} q_{1}+p_{2} q_{2}-c \cdot\left(q_{1}+q_{2}\right)-F=0 \\
& \quad p_{1}, p_{2} \geq 0
\end{aligned}
$$

The solution to the social planner's problem in (1) is a (modified) Ramsey pricing solution:

$$
\left(\frac{p_{1}-c}{p_{1}}\right)=\frac{\mu}{\varepsilon_{1}},\left(\frac{p_{2}-(c-\alpha)}{p_{2}}\right)=\frac{\mu}{\varepsilon_{2}}-\frac{\mu \cdot \alpha}{p_{2}}
$$

where $\mu=-\frac{\lambda}{1+\lambda}, \lambda$ is the Lagrange multiplier related to zero profits, and $\varepsilon_{i}$ is the elasticity of demand for group $i$. Notice how the social planner pays attention not only to the "net mark-up" to the poor (i.e. the amount by which $p_{2}$ exceeds $c-\alpha$ ), but also to the markup on rich individuals (i.e. the amount by which $p_{1}$ exceeds $c$ ). This solution clearly shows that the solution to the social planner's problem cannot be achieved by Bertrand competition between two firms even when the altruist's preferences are the same as those of the social planner. One could use other competitive mechanisms in place of Bertrand but the point would be the same. When market power is needed to provide funds to finance care for the poor, competition can be incompatible with the social optimum. 


\section{Empirical analysis of uncompensated care, nonprofit status, and market power}

As noted above, some degree of market power is a necessary condition for the uninsured to receive care when nonprofit hospitals face a financing constraint. ${ }^{18}$ In general, the link between market power and uncompensated care will depend on the nonprofit hospital's objective function. While it is entirely possible that nonprofit hospitals will direct profits from insured patients towards care for the uninsured, other possibilities, such as opportunistic behavior by nonprofit administrators, the dissipation of rents through possibly inefficient non-price competition, and various forms of regulatory evasion, are also plausible.

Accordingly, whether and to what extent nonprofit hospitals with market power use profits from the insured to subsidize care for the uninsured is an empirical question.

We use an 11-year panel of data on California hospitals from 2001 through 2011 to study changes in charity care provision by nonprofit, for-profit, and government hospitals as the market concentration and competition they face varies. The analysis data set combines financial information, including revenue, profit, and two dollar measures of uncompensated care provision, from the California Office of Statewide Health Planning and Development (OSHPD) Hospital Financial Disclosure Reports with concentration measures derived from the OSHPD Patient Discharge databases. We also use hospital discharge data to construct to

18 In practice, of course, nonprofit hospitals do receive various forms of subsidies, including in the form of tax exemptions. Nevertheless, the point remains that, greater market power can, depending on their objective functions, allow nonprofit hospitals to provide greater amounts of uncompensated care. 
directly measure uncompensated care based on the volume of inpatient care provided to uninsured patients.

\section{IV.A. Measuring uncompensated care}

Both for-profit and nonprofit hospitals provide substantial amounts of uncompensated care (CBO, 2006). Uncompensated care is the most prominent form of reported community benefit; other categories include medical education and training, research, and community programs. ${ }^{19}$ Uncompensated care accounts for $56 \%$ of total community benefits reported by nonprofit hospitals, and the average and median percentages of revenue devoted to uncompensated care were 7\% and 4\% (IRS, 2009). These measures, however, are subject to manipulation; for example, the IRS study finds a great deal of variation in how hospitals measure and report uncompensated care. ${ }^{20}$

In California, for-profit hospitals accounted for more than $20 \%$ of all uncompensated care.

Like their nonprofit counterparts, for-profit hospitals are legally required to treat patients who require immediate medical attention, regardless of their ability to pay, and also may treat

19 Education and training account for $23 \%$ of reported community benefits, medical research accounts for $15 \%$, and community programs account for $6 \%$ (IRS, 2009). Young et al. (2015) provide a more recent examination of community benefits provided by nonprofit hospitals. They report that about $85 \%$ of community benefit expenditures are related to direct patient care (25\% for charity care, $15 \%$ for subsidized health services, and $45 \%$ for unreimbursed costs under non-Medicare government programs).

20 The IRS study reports that roughly one-fifth of hospitals include as uncompensated care each of the following: "the difference between hospital charges and the amount private insurance paid or allowed for services (private insurance shortfalls); the difference between hospital charges and the amount Medicare paid or allowed for services (Medicare shortfalls); the difference between hospital charges and the amount Medicaid allowed for services (Medicaid shortfalls); and the difference between hospital charges and the amount other public insurance programs allowed for services (other public program shortfalls)." Some of these measures appear suspect. For example, including "private insurance shortfalls" in uncompensated care is subject to ready manipulation: a hospital could increase its list charges, offer managed care organizations correspondingly larger discounts, and thereby report higher levels of uncompensated care. 
patients who subsequently turn out either to lack insurance or to fail to pay the out-of-pocket portion of their medical bill. When the hospital approves in advance free or discounted care, such care is considered charity care, and will likely appear in a hospital's financial data as a deduction from revenue under the category of “charity care.” In many cases, a hospital may learn after the fact that the care it provided was partially or entirely uncompensated. This is also accounted for as a deduction from revenue (similar to the accounting treatment of contractual discounts), but is commonly allocated to "bad debt." ${ }^{21}$ In practice, the majority of uncompensated care in California is reported as bad debt rather than as charity care. Generally, hospitals and hospital systems vary in how they allocate uncompensated care into charity care and bad debt. As a result, uncompensated care, defined as the sum of charity care and bad debt, is likely the more reliable dollar-denominated measure of community benefits (CBO, 2006; David and Helmchen, 2006; Garmon, 2009). In the analysis below, we focus both on reported charity care and uncompensated care (defined as charity care + bad debt), but place more focus on the sum.

The value of uncompensated care reported in hospitals’ financial statements may overstate both its market value and its cost. Some hospitals compute charity care and bad debt using the list prices for services as reflected in their chargemasters, which are lengthy menus of somewhat arbitrary list prices (Reinhardt, 2006; IRS, 2009). However, in practice, hospitals rarely if ever receive payment equal to their list charges. Private insurers commonly negotiate discounts under which actual payments may be $40-60 \%$ of list prices. Medicare payments are

21 See, for example, the discussion in Missouri Foundation for Health (2005). 
typically below private rates, and Medicaid rates are usually lower still. The uninsured are often billed full list charges, but they rarely actually pay those bills, which will be reflected in high levels of bad debt.

This method of valuation is likely to lead to biased estimates of charity care provision when inflation of and discounting from list charges are not constant across hospitals. For example, hospitals that provide the same volume of free care but have higher list charges may appear to provide more uncompensated care than hospitals with lower list charges provide. ${ }^{22}$ Crosssectionally, the bias would be particularly severe if hospitals with more market power have a greater ability or propensity to inflate their list charges. Such tendencies, to the extent that they are time-invariant, are diminished by the inclusion of hospital fixed-effects in the econometric analysis. Nevertheless, the concern remains that the within-hospital comovement of charity volume and list charges is responsive to the dynamics of competition. For example, hospitals in markets experiencing consolidation may use their market power to raise list and transaction prices without allocating more resources to enhancing the volume and type of uncompensated care provided.

To avoid these issues and focus on actual services rendered to the poor, we construct a third measure of charity care: the volume of inpatient services provided to uninsured patients. Each year, the Centers for Medicare and Medicaid Services (CMS) computes and publishes DRG “weights.” From 2001 to 2011, the set of inpatient services hospitals offer were divided into roughly 550 Diagnosis Related Groups (DRGs). CMS determines weights for each DRG

22 Garmon (2009) accounts for this by deflating list charges by each hospital's cost-to-charge ratio. 
based upon regular surveys of hospitals’ costs. The weights reflect the relative cost of treating patients in a particular DRG. For example, a patient in a DRG with a weight of 4 is four times as costly on average to treat as a patient in a DRG with a weight of 1 . The volume based measure of care provided to various sets of patients that we analyzed below (e.g., Medicare, Medicaid, privately insured, uninsured, etc.) is computed as the sum of the DRG weights for all patients in a given payer class.

In summary, the three measures we examine are (1) "charity care" — the reported dollars of charity care; (2) “uncompensated care”- the sum of reported dollars of charity care and uncompensated care; and (3) “charity volume” — total inpatient services volume provided to patients without insurance. The first two span all services offered by hospitals, including outpatient and inpatient, but are subject to the limitations described above. The third is more accurately measured and is our preferred measure, though it only captures inpatient care.

In 2008, CMS introduced changes to its DRG system to account for severity (Medicare Severity-DRG, or MS-DRG) that resulted in a complete restructuring of the taxonomy, including an expansion from 538 DRGs to 745 MS-DRGs. The change from DRG to MSDRG “weights” has little effect on our charity care provision analysis because those “weights” are aggregated yearly by payer category.

Figure 2 presents histograms for the three charity measures. Since, all else equal, larger hospitals are expected to provide higher nominal and actual rates of charity care, measures of 
charity are divided by the number of staffed beds for each hospital. Charity measures, adjusted for size, appear to follow a log normal distribution.

Figure 3 presents statewide yearly trends in total charity care, bad debt, and charity volume. Both charity care and bad debt (and thus, the sum of charity care and bad debt) more than tripled between 2001 and 2011. Charity volume, on the other hand, grew by just half over the same period. ${ }^{23}$ This suggests that the growth in charity care and uncompensated care is driven by increases in both charges and patient volume, but more so the former. ${ }^{24}$

\section{IV.B. Measuring competition}

We use a measure of competition that does not require specifying any geographic market or market boundaries (this measure is similar to that used in Kessler and McClellan (2000)). ${ }^{25}$ Our competition measure is constructed as follows. In the first step, we calculate the standard HHI based on observed shares of commercially-insured patients within each unique zip code and Major Diagnostic Category (MDC) combination (a “micromarket”), taking joint

23 Over this same period, the under-65 population of California grew by $8.9 \%$, from 31.2 million to 33.0 million; the size of that group that is uninsured rose slightly to approximately 6.9 million (http://www.census.gov/hhes/www/hlthins/historic/hihistt6.xls). The increase in measured charity volume exceeds the growth in the uninsured population.

24 Nonprofits cannot distribute their profits. However, if profits from excess pricing are dissipated through higher compensation and staff perquisites, a hospital's costs will increase and so will its cost-to-charge ratio. Even holding the actual volume of uncompensated care fixed, this could misleadingly increase the dollardenominated value of uncompensated care. Another factor that could drive greater increases in the dollardenominated measures is that, over time, more services have shifted to the outpatient setting and the charity volume measure only reflects inpatient services. This is unlikely to account for a significant portion of the widening gap because statewide inpatient discharges increased steadily over the sample period.

${ }^{25}$ Imposing arbitrary market definitions, such as counties, health service areas (HSAs), or metropolitan statistical areas (MSAs), may overstate or understate the true size of the market and generate spurious conclusions about the degree of competition faced by specific hospitals, or produce a measure of concentration that has so much measurement error that it would be challenging to identify any relationship between concentration, market power, and charity care. 
ownership into account. ${ }^{26}$ All hospitals that treat patients in a given MDC-zip code pair are part of this HHI calculation, so we do not impose any market boundaries (except insofar as we use data only from the State of California). In the second step, we compute a hospitalspecific HHI for each hospital as the weighted sum of micromarket HHIs, where the weight is the share of that hospital's patients that originate from each zip code-MDC combination. ${ }^{27}$

In general, hospitals that draw patients from more concentrated zip codes and more concentrated service lines will have higher hospital-level HHIs. The higher a hospital's HHI, the weaker is the competitive pressure that it faces. Therefore, not surprisingly, a number of studies have demonstrated that this modified HHI is a good predictor of hospital prices, supporting its use to measure hospitals’ and systems’ market power (Gruber, 1994; Keeler, Melnick, and Zwanzinger, 1999; Dranove and Ludwick, 1999; Capps and Dranove 2004). ${ }^{28}$

26 Because we focus on acute care hospitals, for the purpose of measuring competition, we exclude MDCs 19 (psychiatric care) and 20 (alcohol and drug related admissions), which are also provided by standalone psychiatric hospitals and addiction treatment centers, respectively. Additionally, these services are used disproportionately by the uninsured population and are considered unprofitable; therefore, they are not likely to contribute to or reflect the formation of market power. In order to avoid double-counting labor and delivery admissions, we also exclude DRG 391, the DRG for a normal newborn.

27 Our data for the three measures end in 2011 because the five-digit zip codes needed to match demographic information to corresponding MDC-zip combination are available from California OSHPD only before 2011. In this paper, we only present results that use hospital-specific HHI calculated without hospitals of Kaiser Permanente. The exclusion of Kaiser hospitals is because Kaiser hospitals compete only indirectly with the hospitals we study (Ho and Lee (2013)), whereas our hospital-specific HHIs intend to capture the levels of direct hospital competition. For robustness check, we conduct a set of analysis using hospitalspecific HHI calculated with Kaiser hospitals. Our main results are robust to the inclusion of Kaiser.

28 Kessler and McClellan (2000) noted, correctly, that this competition measure is likely endogenous and proposed constructing the hospital-level HHIs using the predicted values from a discrete choice model that includes only exogenous right hand side variables (rather than observed market shares) to compute the HHI in each micromarket. In practice, estimating 11 years of logit models for the state of California is impractical and, as we show below, the simpler measure based on observed micromarket shares is an effective predictor of hospital pricing. 
Formally, the measure of the degree of competition faced by hospital $j, H o s p-H H I_{j}$, is defined as follows:

$$
H o s p-H H I_{j}=\sum_{z=1}^{Z} \sum_{m=1}^{M}\left(\frac{\text { Hosp. j's patients from zip } z \text { and MDC } m}{\text { Hosp. } j \text { 's total patients }}\right)\left(H H I_{z, m}\right) \text {. }
$$

$H H I_{z, m}$ is the typical $\mathrm{HHI}$, computed as the sum of squared market shares among patients from zip code $z$ with a diagnosis in MDC $m$.

Using this measure of competition addresses the problems raised by pre-specifying a geographic market within which to measure competition. However, the Hosp-HHI may still be subject to endogeneity (e.g., hospitals’ prices determine their market share and thus the HHI, and prices may also affect the provision of charity care). Kessler and McClellan address this issue by substituting for the observed shares within each microsegment the predicted shares from a choice model that uses only exogenous factors (e.g., distance and age) as predictors. This approach is less practical in the current setting because, while Kessler and McClellan compute their concentration measures for heart attack admissions only, we study all acute care inpatient admissions. ${ }^{29}$

We view the concern as minimal. Due to the presence of insurance, the majority of the hospital population faces no variation or very modest variation in prices across in-network hospitals (the same is true of the uninsured, who typically do not pay their inpatient hospital

29 Compared to the data in Kessler and McClellan, our data encompass roughly 20 times as many patients per year and span 11 years rather than four. 
bills). As a result, market shares and HHIs will be affected by prices only to the extent that variation of such prices in our data determine whether hospitals are included in or excluded from insurers’ networks.

This distinction was discussed in detail in Vistnes (2000), who described hospital competition as a "two stage" process. In the first stage, hospitals and insurers negotiate pricing and determine network structure. In the second stage, hospitals compete for patients primarily on the basis of non-price factors. Most hospitals have at least some excess capacity and would find it profitable at the margin to enter agreements with as many insurers as possible. This explains why, in practice, most managed care networks, at least until recently, include most hospitals. ${ }^{30}$ Price, therefore, serves primarily to divide the gains from trade between hospitals and insurers (and insurers' customers). The direct effect of price on patients' choices among in-network hospitals is minimal, so we do not think endogeneity poses a problem in this context. We also explore a sensitivity analysis that replaces the allpatient hospital-HHIs with the hospital-HHIs derived from just enrollees in traditional Medicare. The hospitalization decisions of Medicare enrollees are unlikely to be affected by network restrictions (virtually all hospitals accept Medicare), pricing, or market power (Medicare prices are regulated).

30 This was less true in the 1990s, when HMOs were both more common than PPOs and tended to feature narrower networks. By the end of the 1990s, consumers had largely rejected narrow networks, and HMOs began offering broader networks (which PPOs had always offered). See Draper et al. (2002) and Ginsberg (2005). The appendix in Capps, Dranove, and Satterthwaite (2003) contains a stylized proof showing that insurers have an incentive to assemble expansive hospitals networks. Narrower networks have become somewhat more common in recent years, but that trend was in the very early stages as of 2011, the final year of our data. 


\section{IV.C. Data overview}

Table 1 presents summary statistics describing the time path of the number of hospitals, beds, utilization, financial information, and charity care provision from 2001-2011, separately for nonprofit, for-profit, and government hospitals. Over the sample period, the number of nonprofit hospitals declined by $7.5 \%$ and the number of for-profit hospitals declined by 14.6\%. The bulk of this decline occurred after 2003 and was likely related to requirements that hospitals complete seismic retrofitting by 2006 (some hospitals closed or converted to other uses rather than retrofit; Chang and Jacobson, 2008). Average net income among forprofit hospitals also began a marked decline in 2004. Average net income among nonprofit hospitals, however, increased steadily over the sample period. With the economic recovery following the 2008 financial crisis and recession, however, net income for hospitals of all types had improved by 2011. ${ }^{31}$

Average discharges at the surviving hospitals increased over time, as expected given population growth and hospital closures. The average number of beds increased only slightly between 2001-2011 since exiting hospitals were smaller than average, and then evened out or declined. Consequently, growth in discharges per hospital was primarily the result of higher utilization of existing beds rather than the addition of new beds. ${ }^{32}$

31 California also began Medicaid expansion under a federal waiver in November, 2010, which may have contributed to improved net income in 2011 (Harbage and King, 2012).

32 The average exiting hospital had 101.6 beds while the average surviving hospital (i.e. hospitals appearing in every year of our sample) had 194.2 beds. 
The middle three rows in each panel contain the annual averages of the three measures of charity care: reported charity care, uncompensated care (charity care plus bad debt), and the volume measure of charity care. ${ }^{33}$ At nonprofit hospitals, all three measures grew rapidly over the sample period. Notably, as indicated in Figure 3, the volume-based measure of charity care grew at a much slower rate than either of the two dollar-based measures of charity care. This suggests that some portion of the increase in measured charity care reflects factors other than increasing levels of uncompensated inpatient care. As discussed above, this could result from increases in list charges, decreases in reimbursement for some types of insured patients, or accounting practices that incorporate expenditures not directly related to patient care, such as medical research and teaching, into the reported charity care measures. Government hospitals reported growing levels of charity care and bad debt, but did not provide an increasing volume of inpatient care to the uninsured and indigent (as we show below, however, the level of inpatient care that government hospitals provide to the uninsured was high relative to their scale and revenue and remained so).

Figure 4 charts average trends by ownership type for each of the three measures of charity provision. The left panel reports raw means while the right hand-side panel tracks measures of intensity by dividing each charity measure by the number of staffed beds and averaging it across hospitals within ownership type. Nonprofits saw a sharp increase in all three charity measures over the 2001-2011 period. For-profit hospitals did as well, but the increase was

33 The patient discharge data contain 10 different payer categories. This measured is constructed as the sum of DRG case weights provided to patients for whom the expected payer is either "County Indigent Programs," “Other Indigent”, or "Self Pay.” 
smaller, particularly for the dollar-denominated measures. On a per bed basis, increases in charity care and uncompensated care are similar for all three categories of hospitals. The pattern is different for the volume-based measure. Government hospitals did not increase charity volume, either on an overall or per bed basis. But they consistently provided a much higher level of charity volume than for-profit and nonprofit hospitals. The average nonprofit hospital provided more charity volume than the average for-profit hospital, but the bulk of this difference is attributable to the larger average size of nonprofit hospitals-the per bed charity volume measures are much more similar for the two types of hospitals than the per hospital volume measures.

Summary statistics for scale measures, concentration, and the three charity measures are presented in Table 2. Three Hospital-HHI measures are also summarized: the first is derived from the full sample of patients, the second is based only on privately insured patients, and the third is calculated based only on Medicare patients. Our primary analysis relies on the first measure; the sensitivity analysis presented below discusses reasons for considering these alternative measures and establishes that our results are robust to alternative ways of measuring concentration.

The final column in Table 2 shows that over the full sample period, nonprofit hospitals actually account for a disproportionately low share of total charity care provision, particularly when that care is measured by volume rather than dollars. Despite accounting for $65 \%$ of beds, $67 \%$ of discharges, and $71 \%$ of revenue, nonprofit hospitals account for only $64 \%$ of charity care and bad debt and only $55 \%$ of the total volume of inpatient service provided to 
the uninsured. Perhaps surprisingly, for-profit hospitals actually account for a disproportionately large amount of charity care measured in dollars, though the same is not true for the volume measure. Relative to their overall scale, government hospitals provide a particularly large volume of inpatient care to the uninsured-almost one-third of the total volume of care provided to the uninsured is provided by government hospitals. ${ }^{34}$ They account for $34 \%$ of charity volume even though they account for only $16 \%$ of patient beds, $15 \%$ of discharges, and $15 \%$ of patient revenue.

As suggested by the theoretical section above, the disproportionately low level of charity care provided by nonprofit hospitals could be the result of competitive pressures that preclude charging prices to insured patients that are sufficiently high to facilitate cross-subsidizing uncompensated care. However, Table 2 also shows that nonprofit hospitals on average face less competition than for-profit hospitals. Moreover, while the degree of competition faced by for-profit hospitals has increased slightly over time (the average hospital-HHI for forprofits fell from 3,123 in 2001 to 2,939 in 2011), the degree of competition faced by nonprofit hospitals remained roughly unchanged over the sample period.

\section{IV.D. Results}

The basic regression model posits that charity care measure $m$ is a function of the degree of competition faced by a hospital and of other potential control variables $W_{j, t}$ such as patient

34 Consistent with this evidence that government hospitals are more focused on providing care to the needy, CBO (2006) reports that, for government hospitals, uncompensated care accounts for $13 \%$ of operating expenses, as compared to 4.7 percent at nonprofit hospitals and 4.2 percent at for-profit hospitals. 
mix (e.g., uninsured patients living near a given hospital) or local demographics (e.g., income, urban/rural area):

$$
\operatorname{Ln}(\text { Charity })_{j, t}^{(m)}=\alpha_{\text {Type( }(j)}+\alpha_{j}+\beta_{\text {Type }(j)} \text {Hospital }_{-} H H I_{j, t}+\gamma W_{j, t}+D_{t}+\varepsilon_{j t} .
$$

The first term, $\alpha_{\text {Type }(j)}$, is a constant that is specific to each ownership type and $\alpha_{j}$ is a set of hospital fixed effects. The coefficient on the measure of market power, $\beta_{\text {Type }(j)}$, captures the extent to which hospitals with more market power provide more (or less) charity care. To identify potentially differing propensities to provide more charity care for a given level of market power, we allow the coefficient on the concentration measure to vary according to the ownership type of hospital $j$. That is, $\beta_{\text {Type }(j)}=\beta_{N F P}+\beta_{F P} * 1\left[F P_{j}=1\right]+\beta_{\text {Govt }} * 1\left[G o v t_{j}=1\right] .^{35}$ The test of whether, relative to for-profit hospitals, nonprofit hospitals provide more charity care as they face less competition reduces to a test of whether $\beta_{F P}<0$. That will be our key test for whether the antitrust laws should provide special consideration to nonprofit hospitals. In addition, our specification allows us to test whether, all else equal, nonprofits provide more charity care than for-profits. This is a test for whether the tax exemptions enjoyed by nonprofit hospitals are justified by their provision of uncompensated care. This amounts to a test of whether $\alpha_{F P}<0 .{ }^{36}$

35 1[.] is the indicator function, which equals 1 if the argument is true; $\alpha_{\text {Type }(j)}$ is defined analogously to $\beta_{\text {Type }(j)}$.

36 Strictly speaking, the special case where $\beta_{\mathrm{FP}}<0$ and $\alpha_{\mathrm{FP}}<0$, would indicate that, on average, nonprofit hospitals provide less uncompensated care than other hospital types but, also on average, provide more uncompensated 
We explore two sets of models in the baseline analysis. The first is a set of cross-sectional and fixed effect models, presented in Table 3, which are robust to correlations between unobserved time-invariant hospital-specific factors and the error term. However, to the extent that the provision of charity care is related to time-invariant (or largely so) hospital characteristics (e.g., teaching status, scale, unobservable factors) or factors that are not available on an annual basis (e.g., income of the surrounding area), fixed effects regressions cannot identify potentially important determinants of the provision of charity care. We also perform a set of cross-sectional regressions that include a wider set of hospital and area characteristics (presented in Table 4). Robust standard errors are used in all analyses to account for heteroscedasticity. In addition, in fixed effect models, we cluster the standard errors at the Hospital Referral Region (HRR) level to account for potential correlated standard errors within HRRs. ${ }^{37}$

The hospital characteristics included in the full controls specifications include ownership type, teaching status, discharges, and an indicator for rural hospitals. Area characteristics are computed at the hospital service area (HSA) level and include the median income in each HSA, the 18-65 population, total population, the poverty rate, and the percentages of hospitalized residents that lack insurance and that have private insurance. ${ }^{38}$ The variables

care when their market power increases. This case is more nuanced, as it support differential treatment under the tax code and the antitrust law. Here, we find no evidence that $\beta_{\mathrm{FP}}<0$, so the average level of uncompensated care provision by nonprofits and for-profits is examined solely by focusing on the sign of $\alpha_{\mathrm{FP}}$.

37 HRRs represent regional health care markets for tertiary medical care that generally requires the services of a major referral center. Using this level of aggregation reduces the number of clusters and is therefore would make inference more conservative.

38 HSAs are defined by the Dartmouth Atlas Project and are computed as collections of zip codes "whose residents receive most of their hospitalizations from the hospitals in that area." See http://www.dartmouthatlas.org/faq/data.shtm. For demographic data from the Census, HSA averages are 
describing the payer mix within each HSA are derived from the hospital discharge data and so vary over time; accordingly, these are included in both sets of models.

Our cross-sectional results are presented in the upper panel of Table $3 .{ }^{39}$ In the model without ownership interactions, the coefficient estimates on hospital-HHI are positive and statistically significant for all charity measures, indicating that each rises with concentration. Adding ownership interactions reveals our key finding, namely that there is no statistically significant positive difference between nonprofit and for-profit hospitals in terms of the relationship between concentration and charity care, uncompensated care, or charity volume. (top panel of Table 3, row 2.) If anything, for-profit hospitals on average provide more uncompensated care than nonprofit hospitals as they face less competition (this is evident only for the dollardenominated uncompensated care measure). Government hospitals provide less charity volume in more concentrated markets, but higher levels of charity and uncompensated care. Especially since charity volume is our preferred measure of charity care, the lower provision of charity volume by government hospitals when concentration increases is a surprising finding that we leave for future research.

When hospital fixed-effects are included (lower panel of Table 3) the statistical significance of the baseline relationship between the two dollar-denominated measures of charity care and concentration disappears. Charity volume is not higher in more concentrated markets in all specifications. Importantly, just as before, there is no evidence that the positive effect of

calculated as population-weighted averages of the zip code level means. There are 215 HSAs in California that contain hospitals.

39 The cross-sectional results are robust to clustering at HRR level. 
market power is greater for nonprofit hospitals than for for-profit hospitals on the provision of charity. (bottom panel of Table 3, row 2-none of the coefficients are negative and significant). Overall, the results in Table 3 show no empirical support for the proposition that nonprofit hospitals use greater market power to provide greater public benefits. Thus, we find no evidence to support special treatment for nonprofit hospitals under the antitrust laws.

An intermediate case between the upper and lower panels of Table 3 is presented in Table 4, where instead of including hospital fixed effects, the regression is saturated with hospitallevel and market-level characteristics. ${ }^{40}$ As in the less saturated cross-sectional specifications, there is a statistically significant positive relationship between concentration and charity volume. But there is, again, no statistically significant difference in the effect of concentration on the provision of charity care between for-profit and nonprofit hospitals (see the second row in Table 4). ${ }^{41,42}$

In terms of the level of charity volume, when compared to nonprofit hospitals and controlling for size and market concentration, for-profit hospitals provide lower charity volume on average, though the difference is not statistically significant. ${ }^{43}$ This finding calls into question

40 In Table 4, column (7)-(9), we regress the three charity care measures using full specification but exclude rural hospital from the sample. Rural hospitals usually have high HHIs, but not necessarily high bargaining leverage because insurers don't have a strong incentive to sell in the more rural areas. We exclude those rural high HHI data points and find our results reported below are the same as using full sample.

41 As in Table 3, Table 4 shows that government hospitals' charity volume is either less sensitive to or negatively related to the degree of competition faced by the hospital. That is, government hospitals appear to provide less charity care in more concentrated markets. This is a surprising result that we leave for future research.

42 As in the upper panel of Table 3, results in Table 4 are robust to clustering HRR level.

43 The difference is statistically significant in one specification for uncompensated care, which is the sum of charity care and bad debt. This indicates that the provision of uncompensated care rises with concentration more for the for-profit hospitals than the nonprofits. As we note above, dollar measures of charity care will be inflated by higher list prices and also depend on idiosyncrasies in hospital's accounting practices. 
the special treatment that nonprofit hospitals receive under the tax code. Government hospitals provide substantially higher charity volume (columns (3) (6) and (9) in row 5 of Table 4) than both nonprofit and for-profit hospitals and the differences are statistically significant, even though they report lower levels of charity care and uncompensated care on average.

Other coefficients have reasonable signs. For example, the results in Table 4 show that teaching hospitals provide statistically significantly more charity volume than nonteaching hospitals. Rural hospitals have higher levels of charity and uncompensated care (after controlling for size), but provide less charity volume. ${ }^{44}$ Charity volume rises as median income falls and as the percent uninsured rises. These findings all seem reasonable to us and give us confidence in our results.

As highlighted in the theoretical model, the first step in a cross-subsidization mechanism is price increases to individuals with private insurance. To evaluate this mechanism, and as a basic check of the reasonableness of the market power measure, we replace our dependent variable from Table 4 with price measures. We analyze two price measures of what insured individuals are charged: (1) an overall severity-adjusted price and (2) a price index based on conditions (DRGs) treated at a broad set of hospitals. The results are presented in Table 5.

44 As expected, larger hospitals have higher levels of uncompensated care and charity volume but, as evidenced by the coefficient on the log of total discharges being close to 1 , the effect is roughly proportional to scale. The coefficient on discharges is very close to 1 based for the charity volume measure and is further above 1 for the other two measures. 
We find that our concentration measure (Hosp-HHI) is positively related to prices, and the relationship is robust when hospital fixed effects are included. ${ }^{45}$

\section{IV.E. Provision of unprofitable services}

Nonprofit hospitals could use their profits to provide services that are unprofitable, even if those services are not disproportionately provided to uninsured patients. As noted above, hospital services commonly cited as unprofitable include psychiatric care, rehabilitation, the emergency department, trauma services, burn care, and labor and delivery (McClellan, 1997; Horwitz and Nichols, 2009; Lindrooth et al., 2010). Offer rates for these services by ownership type are presented in Table 6. It is clear from this table that nonprofit and government hospitals are the most common providers of these services. However, as shown in the pattern of results from probit models relating the probability of a hospital offering each of these services to concentration and ownership type (see Table 7), nonprofits are no more likely to offer these services as concentration increases than are for-profit hospitals. These services are generally more likely to be provided by hospitals in more concentrated markets, but this is not confined to nonprofit hospitals. And, for two services-trauma care and burn care- the effect of concentration on the probability of providing these unprofitable or less profitable services is stronger for for-profit hospitals and the effect is statistically significant.

45 For details on the construction of the price indexes, see Appendix C in online appendix. 


\section{IV.F. Sensitivity analyses}

One potential concern is that the measure of competition, the Hosp-HHI, may be

endogenous. Kessler and McClellan (2000) noted, correctly, that this competition measure is

likely endogenous and proposed constructing the hospital-level HHIs using the predicted

values from a discrete choice model that includes only exogenous right hand side variables

(rather than observed market shares) to compute the HHI in each micromarket. As noted

above, this is impractical in the current analysis. As an alternative approach, we construct a

version of the Hosp-HHI that is based solely on patients covered by Traditional Medicare

(i.e., Fee-for-service Medicare). Medicare patients have essentially unfettered choice of

hospitals and, because Medicare pays rates that are set administratively, Medicare patients

also face little if any price variation across hospitals. Therefore, hospitals’ shares among

Medicare patients are very unlikely to be affected by hospital market power or pricing. ${ }^{46}$ As

shown in Appendix B1-B3. The results under this alternative measure of concentration are

very similar to those under the baseline concentration measure. ${ }^{47}$

46 However, hospitals' shares of Medicare patents in certain microsegments (e.g., obstetrics) is an imperfect proxy for the preferences of privately insured patients.

47 Potential omitted variables, such as unobserved hospital quality, raise concerns with regard to obtaining unbiased estimates of $\beta_{\mathrm{FP}}$. If patients can observe changes in quality (even to a limited extent), hospitals with increasing quality are likely to attract more insured and uninsured patients, resulting in both greater market share and more uncompensated care. Therefore, not controlling for hospital quality could result in a bias towards finding a positive relationship between market power and uncompensated care, even when using hospital fixed effects. Similarly, consolidation that results in fewer hospitals would lead to an increase in the number of uninsured patients seen by all hospitals, especially those patients that require emergency care. This somewhat mechanical effect would again suggest finding a positive correlation between market concentration and uncompensated care. However, we find little or no evidence of such an effect. Moreover, since we are interested in whether the relationship varies by type of ownership, it is not obvious that our estimate of such variation would be biased even if quality is endogenous. 
We also considered the possibility that some service lines may be intrinsically unprofitable and also highly concentrated, in which case the apparent "concentration” may in fact be the provision of a community benefit. As a first note, our analysis focuses on acute inpatient care and so our concentration measure excludes two services, psychiatric care and rehabilitation, often cited as unprofitable. ${ }^{48}$ The acute care service lines most often cited as unprofitable include trauma care, burn care, the emergency department, neonatology, and, to a lesser extent, labor and delivery. ${ }^{49}$ Even among these services, however, privately insured patients are likely to be profitable. To explore whether we may be conflating concentration in unprofitable service lines with market power, we also estimate versions of the same models using the Hosp-HHI as constructed only from privately insured patients. The results are very similar to those under the baseline concentration measure and the Medicare-derived measure. ${ }^{50}$ (We revisit unprofitable services below.)

Finally, we also considered the possibility that the results are driven primarily by crosssectional variation rather than within-hospital variation over time. To address this, we estimate the model using only hospitals that are in the bottom and top $25 \%$ of the distribution of changes in the Hosp-HHI from the beginning to the end of the sample. ${ }^{51}$ As shown in Table 8, the results under this restricted sample support our previous finding that nonprofit

48 See McClellan (1997), Horwitz and Nichols (2009), and Lindrooth et al. (2010).

49 Note that visits to the emergency department (ED) are not recorded as inpatient care; only an ED patient who stays overnight would, typically, be admitted to the hospital and treated as an inpatient admission.

50 These tables are omitted but are available upon request.

$5125 \%$ of hospitals had a decrease in the Hosp-HHI of 237 or more and 25\% of hospitals had an increase in the HHI of more than 108 . The former would correspond to a firm with a share of roughly $22 \%$ splitting into two firms; the latter would correspond to a merger of two firms with shares of roughly $7 \%$ each. 
hospitals do not provide statistically significantly more charity care, uncompensated care, or charity volume (relative to for-profit hospitals) as they face less competition. One distinction is that, based on the "large HHI change" restricted sample, concentration is negatively and significantly related to uncompensated care, whereas there is no significant relationship in the full sample analysis. This suggests that the estimated insignificant relationship reported earlier between concentration and uncompensated care in the full sample is primarily driven by cross-sectional rather than time series variation. Although, on the other hand, the relationship between concentration and charity volume stays positive and significant under all specifications in both the full and restricted samples, we are skeptical that increases in concentration will generally result in greater provision of charity care for either nonprofit or for-profit hospitals given the mixed results across different charity care provision measures. Moreover, there is no evidence, in these or prior specifications, that charity care provision by nonprofit hospitals is more responsive to reductions in competition than provision by forprofit hospitals.

As a final, distinct check of our basic result that nonprofits do not increase charity volume as they face less competition, we examine changes in the travel patterns of insured and uninsured patients to hospitals that were in the top $25 \%$ of changes in the hospital-HHI. For these hospitals, the average travel time of privately insured patients increased by roughly 16\% from 2001 to 2007 (from about 20.5 minutes in 2001 to 24 minutes in 2007). This indicates that hospitals that gained market power drew insured patients from a broader area (as opposed to business stealing from nearby rivals). However, there was no corresponding 
increase in the average travel time of uninsured patients, which remained at 23.5 minutes. ${ }^{52}$ That increased market power does not lead to a hospital drawing uninsured patients from a broader area suggests that there is a relatively fixed volume of uninsured patients that hospitals tend to accept, irrespective of their market power.

\section{Conclusion}

Our theoretical model suggests that the welfare implications of less competition among nonprofit hospitals will depend on the link between market power and the provision of uncompensated care. In particular, we show that cross-subsidization facilitated by market power may, theoretically, increase welfare. If the underlying premise that nonprofit hospitals use profits from private paying patients to fund care for the uninsured were borne out empirically, that could indicate a fundamental inconsistency between the tax laws, which offer nonprofits favorable treatment in exchange for community benefits, and the antitrust laws, which do not generally provide favorable treatment in recognition of community benefits. $^{53}$

Our analysis of 2001-2011 data on competition, ownership status, and charity care provision by California hospitals offers no support for according any special antitrust treatment to nonprofit hospitals. We find no evidence that nonprofit hospitals are more likely than for-

52 Similar findings emerge when looking at the upper tail of the travel time distribution. For example the 90th percentile of travel time increased by $27 \%$ (from 41.2 to 52.3 minutes) for privately insured patients and by less than $2 \%$ for the uninsured (from 48 to 48.9 minutes).

53 As noted above, some courts have credited merging hospitals' nonprofit status, but on the expectation that a nonprofit would not raise price in the first place rather than on the expectation that the nonprofit would raise price and use the resulting profits to provide care to the uninsured. 
profit hospitals to provide more charity care in response to an increase in market power. We also test whether nonprofit hospitals facing less competition are more likely to offer unprofitable services and again find no significant differences between nonprofit and forprofit hospitals. Our results therefore provide no empirical justification for applying a different antitrust standard to nonprofit hospitals than to for-profit hospitals.

Our results also allow us to test whether nonprofit hospitals provide more charity care than for-profit hospitals, adjusting for the level of competition. We find no empirical support for this proposition either. Examining the efficacy of the nonprofit tax exemption at promoting charity care is beyond the scope of this paper, but our evidence suggests a potential role for enhanced administrative oversight of nonprofit hospitals. 


\section{References}

Advisory Board. 2013. "Hospitals struggle with challenges to tax-exempt benefits,” December 18. https://www.advisory.com/daily-briefing/2013/12/18/hospitals-struggle-with-challenges-totax-exempt-benefits.

Almond, Douglas, Janet Currie, and Emilia Simeonova. 2010. "Public vs. Private Provision of Charity Care? Evidence from the Expiration of Hill-Burton Requirements in Florida.” NBER Working Paper No. 15798.

Arrow, Kenneth J. 1992. “Uncertainty and the Welfare Economics of Medical Care.” American Economic Review 53(5): 941-73.

Blackstone, Erwin A., and Joseph P. Fuhr Jr. 1992. "An Antitrust Analysis on Non-Profit Hospital Mergers.” Review of Industrial Organization 8(4): 473-90.

Capps, Cory. 2005. “The Quality Effects of Hospital Mergers.” Working Paper.

Capps, Cory, and David Dranove. 2004. "Hospital Consolidation and Negotiated PPO Prices.” Health Affairs 23(2): 175-81.

Capps, Cory, David Dranove, Shane Greenstein, and Mark Satterthwaite. 2002. "Antitrust Policy and Hospital Mergers: Recommendations for a New Approach.” Antitrust Bulletin 47(4): 677704.

Capps, Cory, David Dranove, and Mark Satterthwaite. 2003. "Competition and Market Power in Option Demand Markets.” RAND Journal of Economics 34(4): 737-63.

Carreyrou, John. 2008. “Nonprofit Hospitals Flex Pricing Power.” Wall Street Journal, August 28. http://online.wsj.com/article/SB121986172394776997.html, accessed March 21, 2009.

Carreyrou, John, and Barbara Martinez. 2008. "Nonprofit Hospitals, Once For the Poor, Strike It Rich.” Wall Street Journal, April 4. http://online.wsj.com/article/SB120726201815287955.html, accessed March 21, 2009.

Carlton, Dennis W., Gustavo E. Bamberger, and Roy J. Epstein. 1995. “Antitrust and Higher Education: Was There a Conspiracy to Restrict Financial Aid?” The RAND Journal of Economics 26(1): 131-47.

Chang Y., Tom, and Mireille Jacobson. 2008. "What is the Mission of a Not-for-Profit Hospital: Evidence from California’s Seismic Retrofit Requirements.” MIT, unpublished manuscript.

Congressional Budget Office (CBO). 2006. "Nonprofit Hospitals and the Provision of Community Benefits.” The congress of the United States, Congressional Budget Office, Publication No. 2707.

Connor, Robert A., Roger D. Feldman, and Bryan E. Dowd. 1998. "The Effects of Market Concentration and Horizontal Mergers on Hospital Costs and Prices.” International Journal of the Economics of Business 5(2): 159-80.

Dafny, Leemore. 2009. "Estimation and Identification of Merger Effects: An Application to Hospital Mergers.” Journal of Law \& Economics 52: 523-50.

David, Guy. 2009. "The Convergence between Nonprofit and For-Profit Hospitals in the United States.” International Journal of Health Care Finance and Economics 9(4): 403-28. 
David, Guy and Lorens A. Helmchen. 2006. “An Uncertain Prescription: Are Tax Exemptions for Nonprofit Hospitals an Efficient Way to Fund Indigent Care?” Regulation 29(2): 14-16.

David, Guy, Richard Lindrooth, Lorens A. Helmchen, and Lawton R. Burns. 2014. "Do Hospitals Cross Subsidize?” Journal of Health Economics 37: 198-218.

Doyle, Jim. 2014. “Dispute grows over tax exemptions for nonprofit hospitals.” St. Louis PostDispatch, February 22.

Dranove, David, and Richard Lindrooth. 2003. "Hospital consolidation and costs: another look at the evidence.” Journal of Health Economics 22 (6): 983-97.

Dranove, David, and Richard Ludwick. 1999. “Competition and Pricing by Nonprofit Hospitals: A Reassessment of Lynk’s Analysis.” Journal of Health Economics 18(1): 87-98.

Draper, Debra, Robert E. Hurley, Cara S. Lesser, and Bradley C. Strunk. 2002. “The Changing Face of Managed Care.” Health Affairs 21(1): 11-23.

Duggan, Mark. 2000. “Hospital Ownership and Public Medical Spending.” Quarterly Journal of Economics 115(4): 1343-74.

Duggan, Mark. 2002. “Hospital market structure and the behavior of not-for-profit hospitals.” RAND Journal of Economics 33(3): 433-46.

Garmon, Christopher. 2009. “Hospital Competition and Charity Care.” Frontiers in Health Policy Research, forthcoming.

Gaynor, Martin. 2006. "What Do We Know About Competition and Quality in Health Care Markets?” NBER Working Paper No. 12301.

Gaynor, Martin, and William. B. Vogt. 2000. “Antitrust and Competition in Health Care Markets.” 1406-43, in Newhouse, J. and A. Culyer, eds., Handbook of Health Economics, New York, NY: Elsevier Science.

Ginsburg, Paul. 2005. “Competition in Health Care: Its Evolution over the Past Decade.” Health Affairs 24(6): 1512-22.

Gruber, Jonathan. 1994. “The Effect of Competitive Pressure on Charity: Hospital Responses to Price Shopping in California.” Journal of Health Economics 13(2): 183-212.

Gowrisankaran, Gautam, and Robert Town. 2003. “Competition, Payers, and Hospital Quality.” Health Services Research. 38(6, part 1): 1403-21.

Haas-Wilson, Deborah and Christopher Garmon. 2011. "Hospital Mergers and Competitive Effects: Two Retrospective Analyses.” International Journal of the Economics of Business 18(1):1732.

Hansmann, Henry. 1987. "The effect of tax exemption and other factors on the market share of nonprofit versus for-profit firms.” National Tax Journal 40: 71-82.

Harbage, Peter, and Meredith L. King. 2012. “A Bridge to Reform: California’s Medicaid Section 1115 Waiver,” October, available at http://www.chcf.org/ /media/MEDIA\%20LIBRARY\%20Files/ PDF/PDF\%20B/PDF\%20BridgeToReform1115Waiver.pdf.

Ho, Vivian and Barton Hamilton. 2000. "Hospital mergers and acquisitions: does market consolidation harm patients?” Journal of Health Economics, 19(5): 767-791. 
Ho, Kate and Robin S. Lee. 2013. “Insurer Competition and Negotiated Hospital Prices.” NBER Working Paper No. 19401.

Horwitz, Jill and Austin Nichols. 2009. "Hospital Ownership and Medical Services: Market Mix, Spillover Effects, and Nonprofit Objectives.” Journal of Health Economics, 28(5): 924-37.

Internal Revenue Service. 2009. "IRS Exempt Organizations (TE/GE) Hospital Compliance Project Final Report,” at http:/ /www.irs.gov/charities/charitable/article/0,id=203109,00.html, accessed March 21, 2009.

Keeler, Emmett B., Glenn Melnick, and Jack Zwanziger. 1999. “The Changing Effects of Competition on Non-Profit and For-Profit Hospital Pricing Behavior” Journal of Health Economics 18(1): 69-86.

Kessler, Daniel P, and Mark B. McClellan. 2000. “Is Hospital Competition Socially Wasteful.” Quarterly Journal of Economics 115(2): 577-615.

Krishnan, Ranjani. 2001. "Market Restructuring and Pricing in the Hospital Industry.” Journal of Health Economics 20(2): 213-37.

Krishnan, R. and H. Krishnan, "Effects of hospital mergers and acquisitions on prices.” Journal of Business Research 56(8): 647-56 (2003).

Lindrooth, Richard C., Tamara Kontetzka, Jingsan Zhu, Wei Chen, and Kevin Volpp. “Trends in the Generosity of Medicare Hospital Payment: 1997-2005.” Working paper.

Lynk, William. J. 1994. "Property Rights and the Presumptions of Merger Analysis.” Antitrust Bulletin 39: 363-83.

Lynk, William. J. 1995. “Nonprofit Hospital Mergers and the Exercise of Market Power” Journal of Law and Economics 38(2): 437-461.

Malani, Anup and Guy David. 2008. “Does Non-Profit Status Signal Quality?” Journal of Legal Studies, Vol. 37 (2) Part 1, pp. 551-576.

McClellan, Mark. 1997. “Hospital Reimbursement Incentives: An Empirical Analysis” Journal of Economics and Management Strategy, 6(1): 91-128.

Nicholson, Sean, Mark V. Pauly, Lawton R. Burns, Agnieshka Baumritter, and David A. Asch. 2000. "Measuring Community Benefits Provided by For-Profit and Nonprofit Hospitals." Health Affairs 19(6): 168-77.

Pellegrini, Dan.1989. “Hospital Tax exemption: A Municipal Perspective.” Frontier of Health Services Management 5: 44-6.

Philipson, Tomas J., and Richard A. Posner. 2009. “Antitrust in the Not-For-Profit Sector.” Journal of Law and Economics, 52(1): 1-18.

Prufer, Jens. 2011. “Competition and Mergers among Nonprofits.” Journal of Completion, Law and Economics, 7(1): 69-92.

Reinhardt, Uwe E. 2006. "The Pricing of U.S. Hospital Services: Chaos behind A Veil Of Secrecy.” Health Affairs 25(1): 57-69.

Reinikka, Ritva, and Jakob Svensson. 2010. "Working for God? Evidence from a change in financing of not-for-profit health care providers in Uganda.” Journal of the European Economic Association forthcoming. 
Richman, Barak D. 2008. “Antitrust and Nonprofit Hospital Mergers: A Return to Basics” 156 U. Pa. Law Review 121-50.

Sari, Nazmi. 2002. “Do Competition and Managed Care Improve Quality?” Health Economics 11(7): 571-84.

Sataline, Suzanne. 2010 “Illinois High Court Rules Nonprofit Hospital Can Be Taxed” Wall Street Journal March 19.

Schencker, Lisa. 2015 "Not-for-profit hospital's tax exemption case could signal trouble for others.” Modern Healthcare, July 8.

Schmalensee, Richard. 1981. "Output and Welfare Implications of Monopolistic Third-Degree price Discrimination.” American Economic Review 71: 242-47.

Simpson, John, and Richard Shin. 1998. “Do Nonprofit Hospitals Exercise Market Power?” International Journal of the Economics of Business 5(2): 141-57.

Seaton, Lynnore, and Beth C. Koob. 2009. “Tax-exempt Hospitals and Community Benefit.” The Health Lawyer 21(5): 37-43.

Stensland, Jeffrey, Zachary R. Gaumer, and Mark E. Miller. 2010. "Private-Payer Profits Can Induce Negative Medicare Margins” Health Affairs 29(5); 1-7.

Sutton, John. 1991. Sunk costs and Market Structure. The MIT Press, Cambridge, Massachusetts, 2743.

Tenn, Steven. 2011. "The Price Effects of Hospital Mergers: A Case Study of the Sutter-Summit Transaction.” International Journal of the Economics of Business 18(1):65-82.

Thompson, Aileen. 2011. “The Effect of Hospital Mergers on Inpatient Prices: A Case Study of the New Hanover-Cape Fear Transaction.” International Journal of the Economics of Business 18(1):91-101.

Vita, Michael G., and Seth Sacher. 2001. “The Competitive Effects of Not-For-Profit Hospital Mergers: a Case Study.” Journal of Industrial Economics 49(1):63-84.

Vistnes, Gregory. 2000. “Hospitals, Mergers, and Two-Stage Competition.” Antitrust Law Journal, 67: 671-92.

Young, Gary J., Kamal R. Desai, and Fred J. Hellinger. 2000. “Community Control and Pricing Patterns of Nonprofit Hospitals: An Antitrust Analysis” Journal of Health Politics, Policy and Law 25(6); 1051-81.

Young, Gary, Cia-Hung Chou, Jeffery Alexander, Shoou-Yih D. Lee, and Eli Raver. 2013 "Provision of Community Benefits by Tax-Exempt U.S. Hospitals.” New England Journal of Medicine 368: 1519-1527. 
Figure 1: Graphical analysis of cross-subsidization: Bertrand duopoly versus monopoly

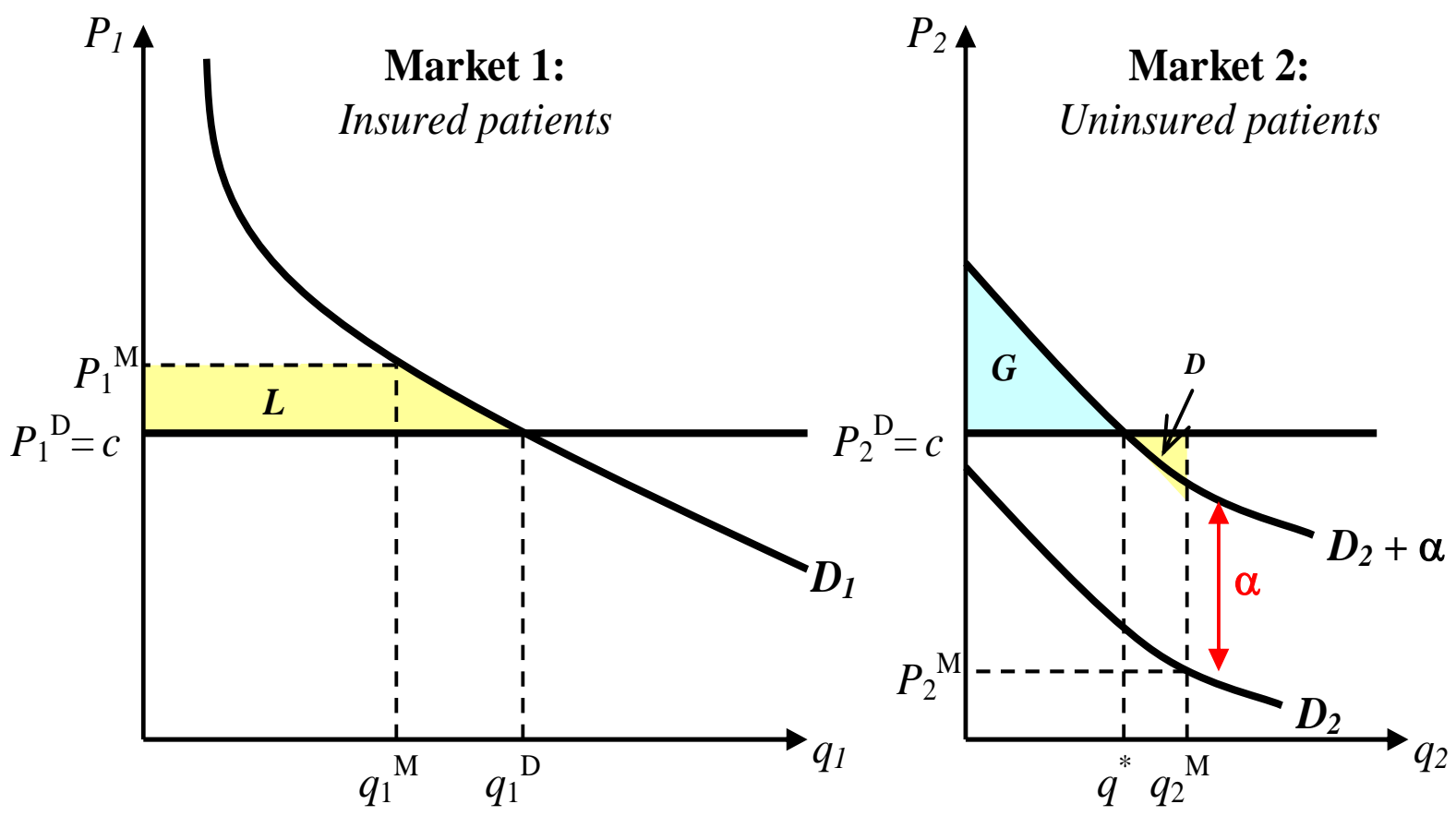


Figure 2: Histograms of Charity Measures (per number of staffed beds)

Ln (Dollars of Charity Care per staffed bed)

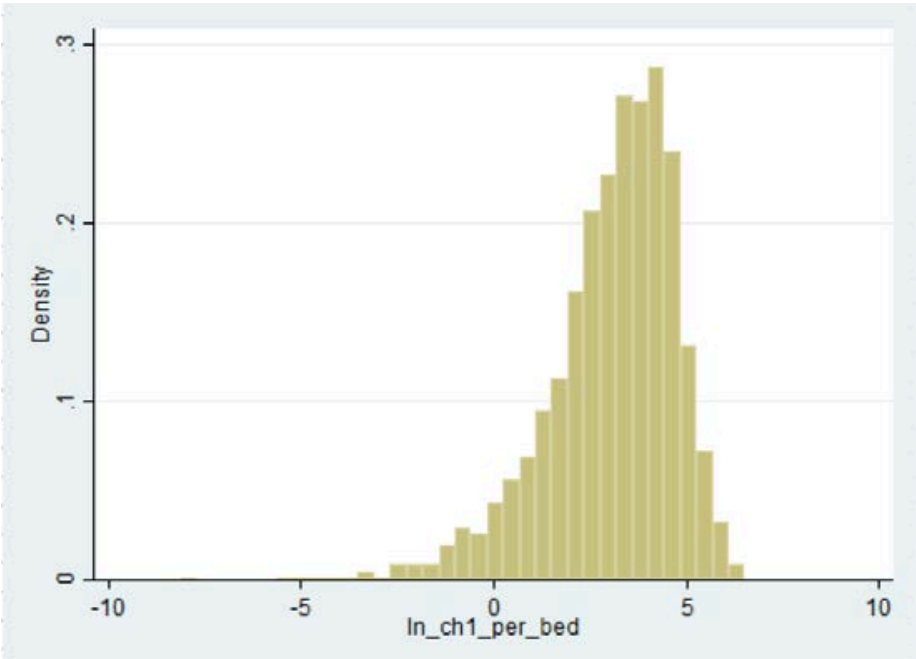

Ln (Dollars of Uncompensated Care per staffed bed)

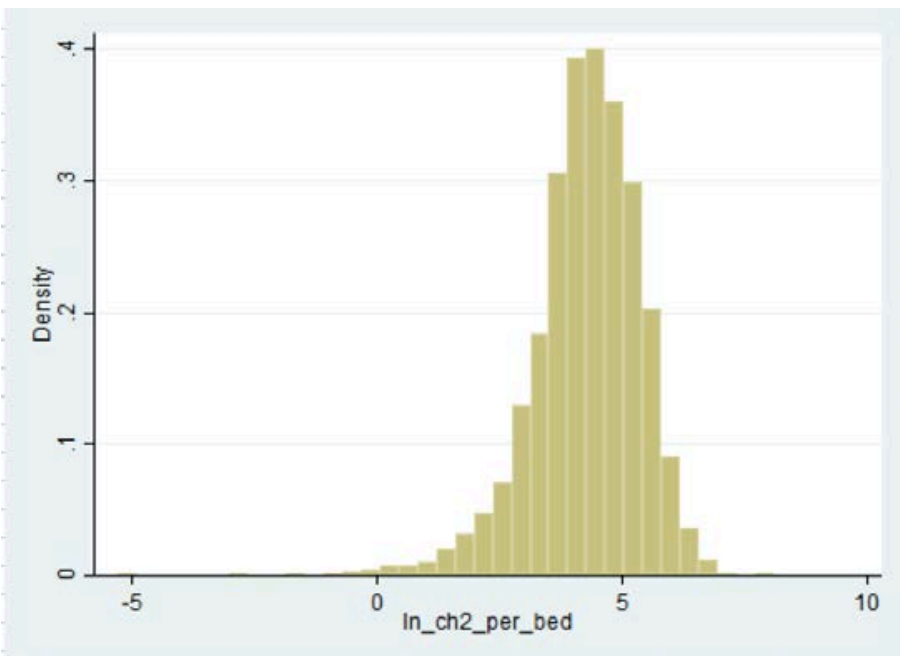

Ln (Charity Volume per Staffed Bed)

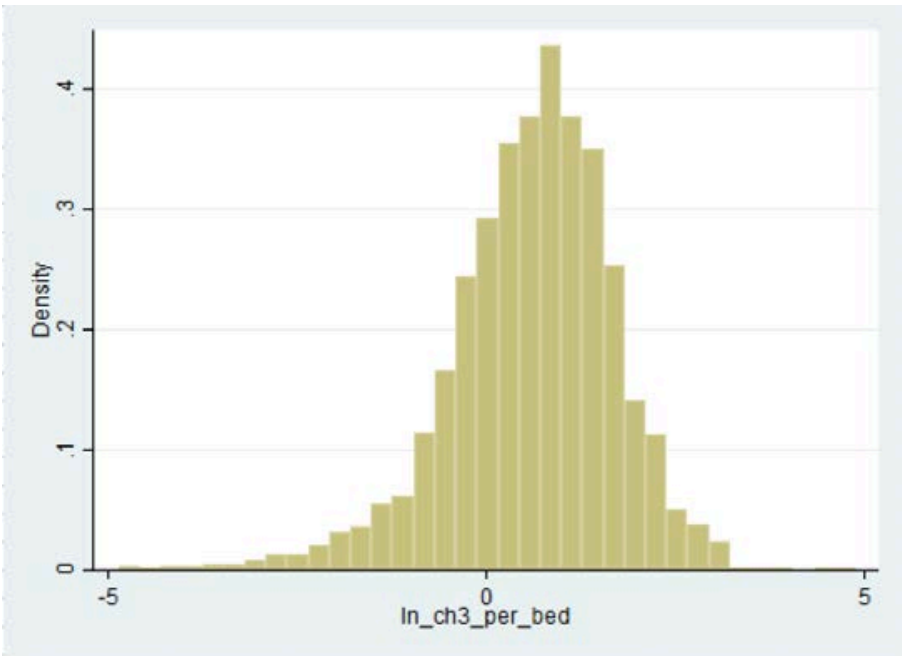


Figure 3: Growth of Charity Care, Bad Debt, and Charity Volume: 2001-2011

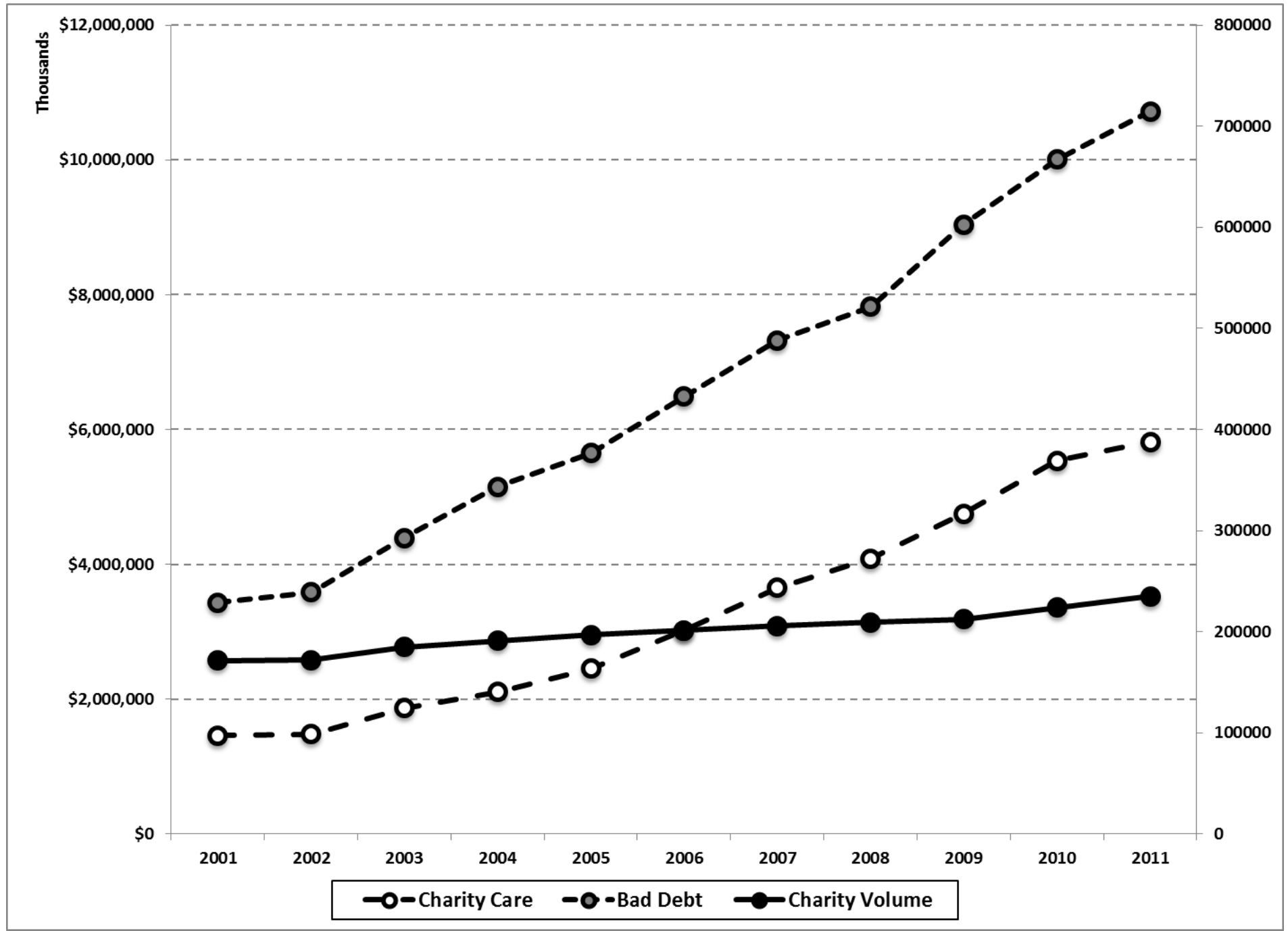

Note: left scale applies to charity care and bad debt; right scale applies to charity volume. 
Figure 4: Average Hospital Trends for the Three Measures: $2001-2011$
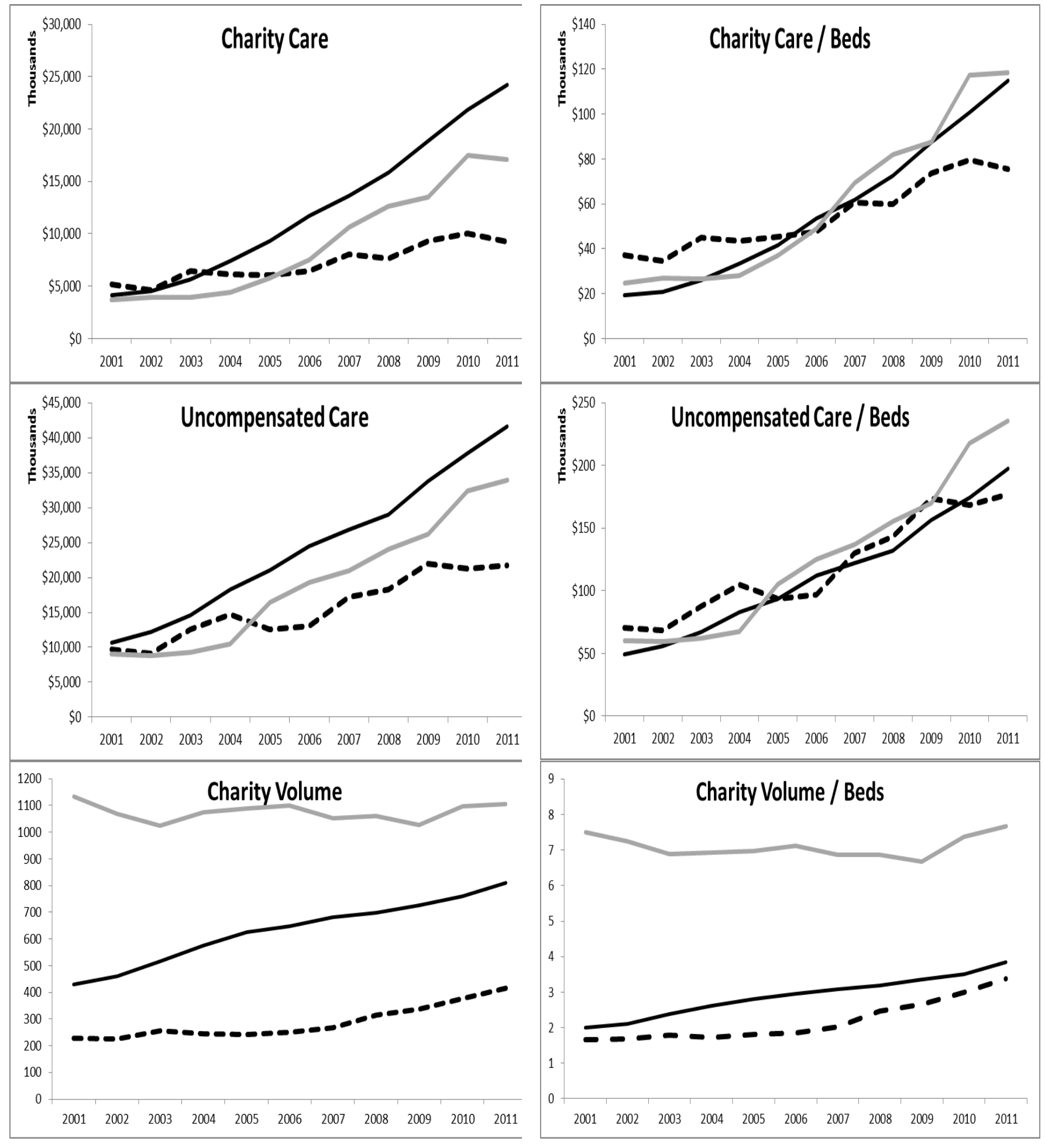

Nonprofit Hospitals - ב-_-. For-Profit Hospitals

Government Hospitals 
Figure 5: Hospital Service Areas (HSAs) in California

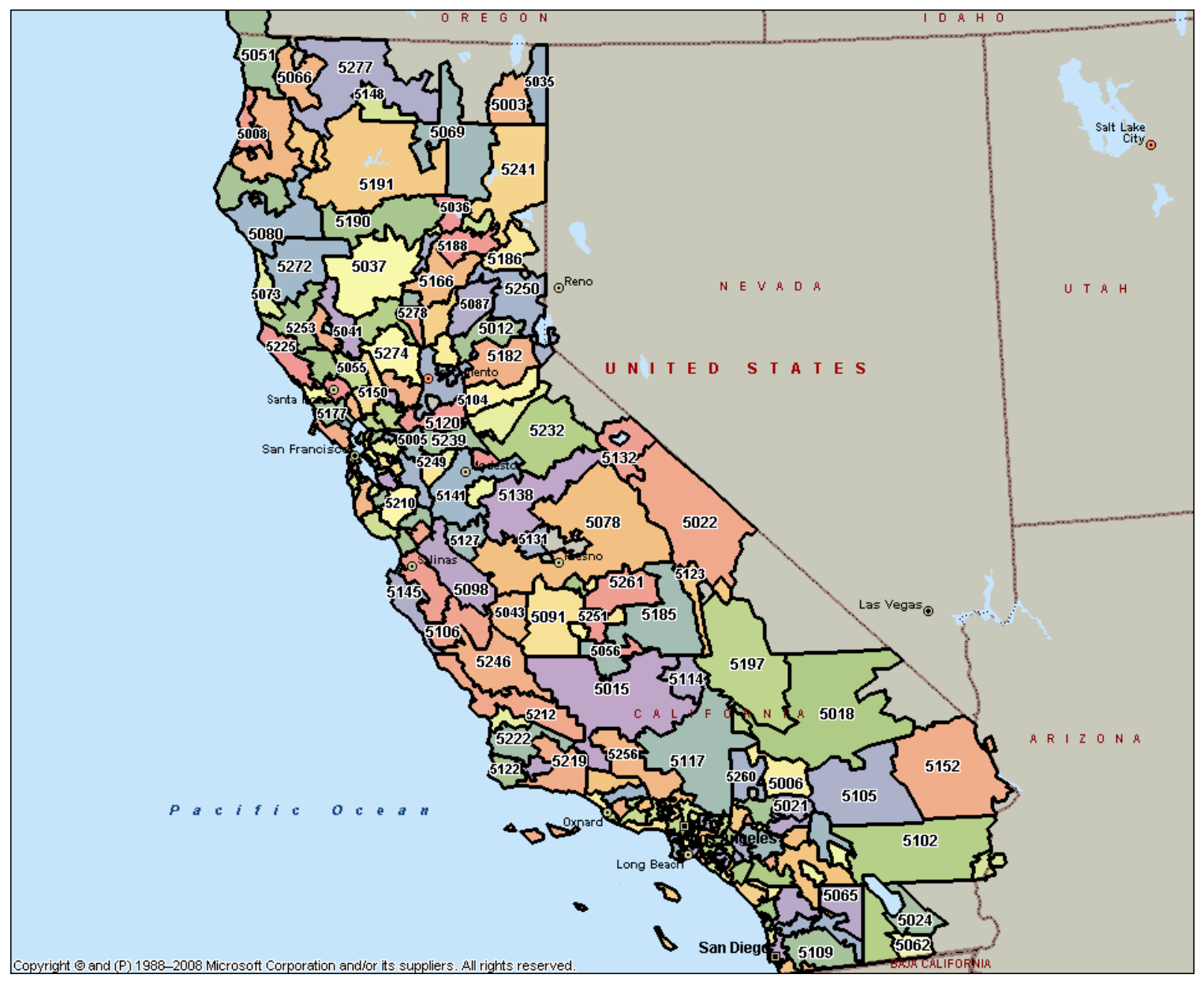


Table 1: Summary data for California hospitals by ownership type and year, 2001-2011

\begin{tabular}{|c|c|c|c|c|c|c|c|c|c|c|c|c|}
\hline & Control Variable & 2001 & 2002 & 2003 & 2004 & 2005 & 2006 & 2007 & 2008 & 2009 & 2010 & 2011 \\
\hline \multirow{11}{*}{$\begin{array}{l}\stackrel{H}{0} \\
\stackrel{0}{0} \\
\stackrel{0}{0} \\
\text { Z } \\
\text { Z }\end{array}$} & $\mathrm{N}$ & 188 & 181 & 185 & 179 & 174 & 174 & 173 & 172 & 169 & 171 & 168 \\
\hline & Beds - staffed & 215 & 219 & 217 & 220 & 224 & 218 & 221 & 219 & 216 & 217 & 211 \\
\hline & Discharges & 10,245 & 10,316 & 10,639 & 11,022 & 11,435 & 11,390 & 11,500 & 11,654 & 11,729 & 11,790 & 11,782 \\
\hline & Gross IP Rev (\$1000s) & $\$ 264,565$ & $\$ 312,905$ & $\$ 372,221$ & $\$ 434,502$ & $\$ 498,698$ & $\$ 546,589$ & $\$ 599,348$ & $\$ 657,398$ & $\$ 724,332$ & $\$ 773,276$ & $\$ 825,586$ \\
\hline & Net income $(\$ 1000 s)$ & $\$ 5,486$ & $\$ 7,493$ & $\$ 7,696$ & $\$ 8,662$ & $\$ 11,374$ & $\$ 16,016$ & $\$ 19,765$ & $\$ 11,023$ & $\$ 12,885$ & $\$ 21,398$ & $\$ 26,990$ \\
\hline & Charity (\$1000s) & $\$ 4,124$ & $\$ 4,520$ & $\$ 5,650$ & $\$ 7,365$ & $\$ 9,335$ & $\$ 11,713$ & $\$ 13,617$ & $\$ 15,875$ & $\$ 18,879$ & $\$ 21,849$ & $\$ 24,219$ \\
\hline & Charity + Bad debt $(\$ 1000 s)$ & $\$ 10,662$ & $\$ 12,239$ & $\$ 14,548$ & $\$ 18,232$ & $\$ 20,963$ & $\$ 24,468$ & $\$ 26,899$ & $\$ 28,940$ & $\$ 33,727$ & $\$ 37,834$ & $\$ 41,601$ \\
\hline & Charity: Volume measure & 431 & 462 & 517 & 575 & 626 & 647 & 681 & 699 & 725 & 760 & 809 \\
\hline & Hospital-HHI: Full sample & 4,173 & 4,258 & 4,239 & 4,212 & 4,232 & 4,256 & 4,260 & 4,269 & 4,318 & 4,281 & 4,262 \\
\hline & Hospital-HHI: Private & 4,278 & 4,298 & 4,260 & 4,203 & 4,187 & 4,220 & 4,222 & 4,225 & 4,279 & 4,260 & 4,252 \\
\hline & Hospital-HHI: Medicare & 4,936 & 4,994 & 5,048 & 5,035 & 5,055 & 5,055 & 5,053 & 5,046 & 5,095 & 5,016 & 4,988 \\
\hline \multirow{11}{*}{ 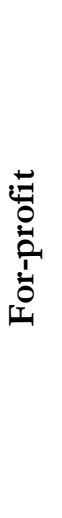 } & $\mathrm{N}$ & 89 & 88 & 87 & 83 & 76 & 78 & 77 & 74 & 78 & 75 & 76 \\
\hline & Beds - staffed & 138 & 134 & 144 & 141 & 134 & 135 & 133 & 128 & 127 & 126 & 123 \\
\hline & Discharges & 6,211 & 6,339 & 6,718 & 6,485 & 6,720 & 7,012 & 6,985 & 6,950 & 7,121 & 6,981 & 6,961 \\
\hline & Gross IP Rev (\$1000s) & $\$ 215,432$ & $\$ 255,041$ & $\$ 323,748$ & $\$ 314,930$ & $\$ 333,097$ & $\$ 351,082$ & $\$ 366,044$ & $\$ 376,114$ & $\$ 398,558$ & $\$ 409,808$ & $\$ 430,973$ \\
\hline & Net income (\$1000s) & $\$ 7,271$ & $\$ 7,339$ & $\$ 8,947$ & $(\$ 923)$ & $\$ 1,851$ & $\$ 935$ & $\$ 450$ & $\$ 3,082$ & $\$ 6,284$ & $\$ 8,105$ & $\$ 8,694$ \\
\hline & Charity (\$1000s) & $\$ 5,145$ & $\$ 4,622$ & $\$ 6,460$ & $\$ 6,134$ & $\$ 6,069$ & $\$ 6,459$ & $\$ 8,042$ & $\$ 7,662$ & $\$ 9,319$ & $\$ 10,003$ & $\$ 9,270$ \\
\hline & Charity + Bad debt $(\$ 1000 s)$ & $\$ 9,713$ & $\$ 9,151$ & $\$ 12,608$ & $\$ 14,763$ & $\$ 12,516$ & $\$ 13,074$ & $\$ 17,223$ & $\$ 18,311$ & $\$ 22,020$ & $\$ 21,228$ & $\$ 21,790$ \\
\hline & Charity: Volume measure & 229 & 227 & 257 & 245 & 242 & 250 & 268 & 316 & 337 & 377 & 415 \\
\hline & Hospital-HHI: Full sample & 3,123 & 3,102 & 3,151 & 3,101 & 3,031 & 2,981 & 2,993 & 2,898 & 2,935 & 2,934 & 2,939 \\
\hline & Hospital-HHI: Private & 3,129 & 3,095 & 3,127 & 3,168 & 3,039 & 2,969 & 3,028 & 2,954 & 2,937 & 2,949 & 2,945 \\
\hline & Hospital-HHI: Medicare & 3,694 & 3,626 & 3,700 & 3,644 & 3,561 & 3,538 & 3,561 & 3,465 & 3,528 & 3,521 & 3,565 \\
\hline \multirow{11}{*}{ 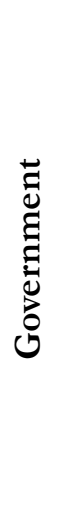 } & $\mathrm{N}$ & 62 & 64 & 65 & 63 & 64 & 63 & 64 & 62 & 62 & 60 & 61 \\
\hline & Beds - staffed & 151 & 148 & 149 & 155 & 156 & 154 & 153 & 155 & 154 & 149 & 144 \\
\hline & Discharges & 6,941 & 6,754 & 6,780 & 7,042 & 7,160 & 7,356 & 7,275 & 7,273 & 7,001 & 7,254 & 6,932 \\
\hline & Gross IP Rev (\$1000s) & $\$ 141,456$ & $\$ 158,195$ & $\$ 176,217$ & $\$ 197,188$ & $\$ 215,932$ & $\$ 235,677$ & $\$ 246,953$ & $\$ 265,940$ & $\$ 282,339$ & $\$ 309,668$ & $\$ 323,240$ \\
\hline & Net income $(\$ 1000 \mathrm{~s})$ & $\$ 21,163$ & $\$ 19,871$ & $\$ 20,977$ & $\$ 22,035$ & $\$ 26,554$ & $\$ 3,991$ & $\$ 4,629$ & $\$ 2,236$ & $\$ 1,712$ & $\$ 752$ & $\$ 15,404$ \\
\hline & Charity (\$1000s) & $\$ 3,711$ & $\$ 3,953$ & $\$ 3,963$ & $\$ 4,378$ & $\$ 5,739$ & $\$ 7,546$ & $\$ 10,607$ & $\$ 12,653$ & $\$ 13,466$ & $\$ 17,463$ & $\$ 17,074$ \\
\hline & Charity + Bad debt $(\$ 1000 s)$ & $\$ 9,077$ & $\$ 8,796$ & $\$ 9,245$ & $\$ 10,499$ & $\$ 16,395$ & $\$ 19,261$ & $\$ 20,951$ & $\$ 24,066$ & $\$ 26,184$ & $\$ 32,385$ & $\$ 33,957$ \\
\hline & Charity: Volume measure & 1,135 & 1,069 & 1025 & 1,075 & 1,088 & 1,100 & 1,052 & 1,060 & 1,026 & 1,096 & 1,106 \\
\hline & Hospital-HHI: Full sample & 4,289 & 4,204 & 4,200 & 4,179 & 4,121 & 4,133 & 4,071 & 4,095 & 4,259 & 4,128 & 4,237 \\
\hline & Hospital-HHI: Private & 4,407 & 4,278 & 4,281 & 4,273 & 4,296 & 4,209 & 4,155 & 4,242 & 4,368 & 4,426 & 4,316 \\
\hline & Hospital-HHI: Medicare & 5,032 & 4,881 & 4,888 & 4,964 & 4,852 & 4,848 & 4,782 & 4,821 & 5,012 & 4,869 & 4,903 \\
\hline \multicolumn{2}{|c|}{ Medical care CPI $(2001=100)$} & 100 & 104.69 & 108.91 & 113.67 & 118.48 & 123.24 & 128.69 & 133.45 & 137.72 & 142.4 & 146.68 \\
\hline
\end{tabular}


Table 2: Scale and charity provision by ownership type, full sample period

\begin{tabular}{|c|c|c|c|c|c|c|c|}
\hline & & Control Variable & Mean & S.D. & Min & Max & $\%$ of Total \\
\hline \multirow{9}{*}{ 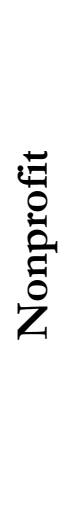 } & \multirow{9}{*}{ 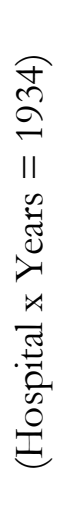 } & Beds - staffed & 218 & 160 & 10 & 931 & $65.49 \%$ \\
\hline & & Discharges & 11,209 & 8,128 & 24 & 50,600 & $66.69 \%$ \\
\hline & & Net patient rev. ( $\$ 1000$ s) & $\$ 211,350$ & $\$ 238,280$ & $\$ 1,810$ & $\$ 2,174,905$ & $71.09 \%$ \\
\hline & & Charity & $\$ 12,255$ & $\$ 20,686$ & $\$$ & $\$ 232,742$ & $65.44 \%$ \\
\hline & & Charity + Bad debt & $\$ 24,234$ & $\$ 30,157$ & $\$$ & $\$ 311,465$ & $63.68 \%$ \\
\hline & & Charity: Volume measure & 626 & 815 & - & 6,322 & $54.94 \%$ \\
\hline & & Hospital-HHI: Full Sample & 4,250 & 1,530 & 1,630 & 8,633 & $59.73 \%$ \\
\hline & & Hospital-HHI: Private & 4,244 & 1,418 & 1,857 & 10,000 & $59.39 \%$ \\
\hline & & Hospital-HHI: Medicare & 5,029 & 1,616 & 1,701 & 9,189 & $59.71 \%$ \\
\hline \multirow{9}{*}{ 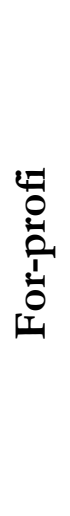 } & \multirow{9}{*}{ 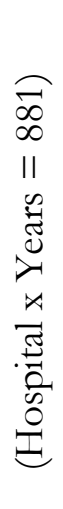 } & Beds - staffed & 133 & 86 & 2 & 434 & $18.25 \%$ \\
\hline & & Discharges & 6,755 & 4,627 & 154 & 22,689 & $18.31 \%$ \\
\hline & & Net patient rev. ( $\$ 1000$ s) & $\$ 90,809$ & $\$ 79,536$ & $\$ 2,896$ & $\$ 489,343$ & $13.91 \%$ \\
\hline & & Charity & $\$ 7,115$ & $\$ 12,459$ & $\$$ & $\$ 104,170$ & $17.31 \%$ \\
\hline & & Charity + Bad debt & $\$ 15,448$ & $\$ 18,785$ & $(\$ 3,260)$ & $\$ 178,236$ & $18.49 \%$ \\
\hline & & Charity: Volume measure & 285 & 316 & - & 1,897 & $11.39 \%$ \\
\hline & & Hospital-HHI: Full Sample & 3,022 & 1,185 & 1,240 & 7,913 & $19.35 \%$ \\
\hline & & Hospital-HHI: Private & 3,036 & 1,097 & 778 & 8,140 & $19.24 \%$ \\
\hline & & Hospital-HHI: Medicare & 3,586 & 1,234 & 1,670 & 8,803 & $19.51 \%$ \\
\hline \multirow{9}{*}{ 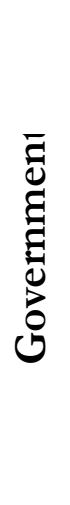 } & \multirow{9}{*}{ 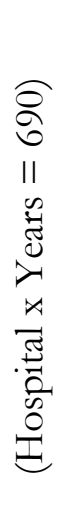 } & Beds - staffed & 152 & 144 & 8 & 737 & $16.26 \%$ \\
\hline & & Discharges & 7,069 & 8,286 & 24 & 44,559 & $15.00 \%$ \\
\hline & & Net patient rev. ( $\$ 1000$ s) & $\$ 125,011$ & $\$ 167,322$ & $\$ 2,490$ & $\$ 994,627$ & $15.00 \%$ \\
\hline & & Charity & $\$ 9,053$ & $\$ 28,475$ & $\$$ & $\$ 284,893$ & $17.25 \%$ \\
\hline & & Charity + Bad debt & $\$ 19,017$ & $\$ 40,399$ & $\$$ & $\$ 302,435$ & $17.83 \%$ \\
\hline & & Charity: Volume measure & 1,075 & 2,065 & - & 17,172 & $33.66 \%$ \\
\hline & & Hospital-HHI: Full Sample & 4,174 & 1,219 & 1,618 & 8,561 & $20.93 \%$ \\
\hline & & Hospital-HHI: Private & 4,294 & 1,405 & 1,689 & 10,000 & $21.37 \%$ \\
\hline & & Hospital-HHI: Medicare & 4,895 & 1,323 & 1,717 & 9,192 & $20.79 \%$ \\
\hline
\end{tabular}


Table 3: Cross-sectional and fixed effects results, log-log specifications

\begin{tabular}{|c|c|c|c|c|c|c|c|c|c|}
\hline & [1] & [2] & [3] & {$[4]$} & [5] & [6] & [7] & [8] & [9] \\
\hline & \multicolumn{3}{|c|}{ No ow nership interactions[A] } & \multicolumn{3}{|c|}{ Ownership interactions [A] } & \multicolumn{3}{|c|}{ Payer mix controls $[\mathrm{B}]$} \\
\hline & Charity Care & Uncomp. Care & Charity Volume & Charity Care & Uncomp. Care & Charity Volume & Charity Care & Uncomp. Care & Charity Volume \\
\hline \multicolumn{10}{|l|}{ Cross-Sectional } \\
\hline Ln(Hosp-HHI) & $\begin{array}{c}0.872^{* * *} \\
(0.116)\end{array}$ & $\begin{array}{c}0.264 * * * \\
(0.0497)\end{array}$ & $\begin{array}{c}0.316^{* * *} \\
(0.0394)\end{array}$ & $\begin{array}{c}0.456^{* * *} \\
(0.114)\end{array}$ & $\begin{array}{c}0.0755 \\
(0.0520)\end{array}$ & $\begin{array}{c}0.480^{* * *} \\
(0.0483)\end{array}$ & $\begin{array}{c}0.473^{* * *} \\
(0.121)\end{array}$ & $\begin{array}{c}0.158^{* * *} \\
(0.0562)\end{array}$ & $\begin{array}{c}0.635^{* * *} \\
(0.0487)\end{array}$ \\
\hline Ln(Hosp-HHI) $*$ For-Profit & & & & $\begin{array}{l}-0.210 \\
(0.291)\end{array}$ & $\begin{array}{c}0.324 * * * \\
(0.124)\end{array}$ & $\begin{array}{l}0.0129 \\
(0.101)\end{array}$ & $\begin{array}{l}-0.214 \\
(0.294)\end{array}$ & $\begin{array}{c}0.280 * * \\
(0.126)\end{array}$ & $\begin{array}{l}-0.0442 \\
(0.0977)\end{array}$ \\
\hline Ln $($ Hosp-HHI $) *$ Government & & & & $\begin{array}{c}3.176^{* * *} \\
(0.473)\end{array}$ & $\begin{array}{c}0.693^{* * *} \\
(0.201)\end{array}$ & $\begin{array}{c}-1.130 * * * \\
(0.105)\end{array}$ & $\begin{array}{c}3.153^{* * *} \\
(0.478)\end{array}$ & $\begin{array}{c}0.599 * * * \\
(0.207)\end{array}$ & $\begin{array}{c}-1.328^{* * *} \\
(0.102)\end{array}$ \\
\hline $\begin{array}{l}\text { Observations } \\
\text { R-squared }\end{array}$ & $\begin{array}{l}3,505 \\
0.429\end{array}$ & $\begin{array}{l}3,502 \\
0.604\end{array}$ & $\begin{array}{l}3,505 \\
0.708\end{array}$ & $\begin{array}{l}3,505 \\
0.446\end{array}$ & $\begin{array}{l}3,502 \\
0.607\end{array}$ & $\begin{array}{l}3,505 \\
0.716\end{array}$ & $\begin{array}{l}3,505 \\
0.446\end{array}$ & $\begin{array}{l}3,502 \\
0.609\end{array}$ & $\begin{array}{l}3,505 \\
0.728\end{array}$ \\
\hline Ln(Hosp-HHI) * For-Profit & & & & $\begin{array}{l}0.0649 * \\
(0.0378)\end{array}$ & $\begin{array}{c}-0.0125 \\
(0.00848)\end{array}$ & $\begin{array}{c}0.0214 \\
(0.0168)\end{array}$ & $\begin{array}{l}0.0631^{*} \\
(0.0368)\end{array}$ & $\begin{array}{c}-0.0128 \\
(0.00811)\end{array}$ & $\begin{array}{c}0.0261 \\
(0.0194)\end{array}$ \\
\hline Ln(Hosp-HHI) ${ }^{*}$ Government & & & & $\begin{array}{l}0.0978 \\
(0.121)\end{array}$ & $\begin{array}{c}0.0249 \\
(0.0338)\end{array}$ & $\begin{array}{c}0.0110 \\
(0.0189)\end{array}$ & $\begin{array}{l}0.0993 \\
(0.121)\end{array}$ & $\begin{array}{c}0.0253 \\
(0.0340)\end{array}$ & $\begin{array}{l}0.00780 \\
(0.0157)\end{array}$ \\
\hline Observations & 3,505 & 3,502 & 3,505 & 3,505 & 3,502 & 3,505 & 3,505 & 3,502 & 3,505 \\
\hline R-squared & 0.793 & 0.840 & 0.928 & 0.793 & 0.840 & 0.928 & 0.793 & 0.840 & 0.934 \\
\hline
\end{tabular}

[A] Specification also includes year dummies, For-profit and Government hospital dummies, Ln(Total Discharges)

[B] Specification also includes year dummies, For-profit and Government hospital dummies, Ln(Total Discharges), HSA \% Privately insured, HSA \% Self-pay

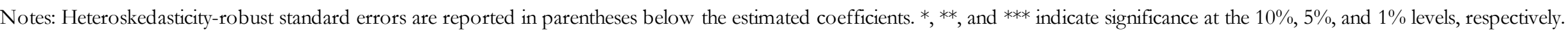
Errors in the hospital fixed-effect models are clustered on HRR 
Table 4: Full covariates results, log-log specification

\begin{tabular}{|c|c|c|c|c|c|c|c|c|c|}
\hline & [1] & [2] & [3] & [4] & [5] & [6] & [7] & [8] & [9] \\
\hline & \multicolumn{3}{|c|}{ Full sample } & \multicolumn{3}{|c|}{ Full sample, including HRR fixed effects } & \multicolumn{3}{|c|}{ Excluding rural hospitals } \\
\hline & Charity care & Uncomp. care & Charity volume & Charity care & Uncomp. care & Charity volume & Charity care & Uncomp. care & Charity volume \\
\hline \multirow[t]{2}{*}{ Ln (Hosp-HHI) } & $0.261^{* *}$ & 0.0751 & $0.628^{* * *}$ & 0.160 & 0.0120 & $0.453^{* * *}$ & $0.387^{* * *}$ & $0.162 * *$ & $0.527^{* * *}$ \\
\hline & $(0.132)$ & $(0.0578)$ & $(0.0517)$ & $(0.226)$ & $(0.0987)$ & $(0.0801)$ & $(0.145)$ & $(0.0633)$ & $(0.0607)$ \\
\hline \multirow[t]{2}{*}{ Ln (Hosp-HHI) x For-profit } & -0.320 & $0.234^{*}$ & -0.0780 & -0.451 & $0.231 *$ & 0.0511 & -0.380 & 0.164 & -0.00378 \\
\hline & $(0.295)$ & $(0.126)$ & $(0.0990)$ & $(0.319)$ & $(0.123)$ & $(0.110)$ & $(0.323)$ & $(0.113)$ & $(0.115)$ \\
\hline \multirow[t]{2}{*}{ Ln (Hosp-HHI) x Government } & $3.125^{* * *}$ & $0.610^{* * *}$ & $-1.158^{* * *}$ & $3.159^{* * *}$ & $0.750^{* * *}$ & $-1.156^{* * *}$ & $8.015^{* * *}$ & $2.223^{* * *}$ & $-1.724 * * *$ \\
\hline & $(0.466)$ & $(0.192)$ & $(0.0974)$ & $(0.559)$ & $(0.223)$ & $(0.115)$ & $(0.673)$ & $(0.312)$ & $(0.155)$ \\
\hline \multirow[t]{2}{*}{ For-profit } & 2.207 & $-1.904 *$ & 0.517 & 3.256 & $-1.859^{*}$ & -0.545 & 2.938 & -1.216 & -0.117 \\
\hline & $(2.382)$ & $(1.016)$ & $(0.812)$ & $(2.576)$ & $(0.994)$ & $(0.895)$ & $(2.607)$ & $(0.917)$ & $(0.934)$ \\
\hline \multirow[t]{2}{*}{ Government } & $-27.53^{* * *}$ & $-5.353^{* * *}$ & $10.07^{* * *}$ & $-27.84 * * *$ & $-6.527 * * *$ & $10.13^{* * *}$ & $-68.60^{* * *}$ & $-18.85^{* * *}$ & $15.00^{* * *}$ \\
\hline & $(3.937)$ & $(1.623)$ & $(0.819)$ & $(4.690)$ & $(1.872)$ & $(0.965)$ & $(5.617)$ & $(2.619)$ & $(1.299)$ \\
\hline \multirow[t]{2}{*}{ Teaching hospital } & -0.0329 & 0.0875 & $0.623^{* * *}$ & -0.251 & 0.0124 & $0.604^{* * *}$ & $0.711 * * *$ & $0.279^{* * *}$ & $0.514^{* * *}$ \\
\hline & $(0.191)$ & $(0.114)$ & $(0.0649)$ & $(0.192)$ & $(0.120)$ & $(0.0655)$ & $(0.177)$ & $(0.104)$ & $(0.0729)$ \\
\hline \multirow[t]{2}{*}{ Ln (Total discharges) } & $1.494^{* * *}$ & $1.028^{* * *}$ & $1.074^{* * *}$ & $1.516^{* * *}$ & $1.012^{* * *}$ & $1.083^{* * *}$ & $1.743^{* * *}$ & $1.179 * * *$ & $1.026^{* * *}$ \\
\hline & $(0.0560)$ & $(0.0295)$ & $(0.0217)$ & $(0.0583)$ & $(0.0342)$ & $(0.0245)$ & $(0.0623)$ & $(0.0380)$ & $(0.0295)$ \\
\hline \multirow[t]{2}{*}{ Rural hospital } & $0.636^{* * *}$ & $0.231^{* * *}$ & $-0.207 * * *$ & $0.797 * * *$ & $0.242^{* * *}$ & $-0.240^{* * *}$ & & & \\
\hline & $(0.138)$ & $(0.0605)$ & $(0.0437)$ & $(0.144)$ & $(0.0630)$ & $(0.0458)$ & & & \\
\hline \multirow[t]{2}{*}{ Ln (HSA population) } & $-0.106^{* *}$ & $-0.0528^{* *}$ & $-0.0734 * * *$ & $-0.208^{* * *}$ & $-0.0841^{* * *}$ & $-0.0659 * * *$ & $-0.227 * * *$ & $-0.102^{* * *}$ & $-0.0822 * * *$ \\
\hline & $(0.0483)$ & $(0.0215)$ & $(0.0171)$ & $(0.0513)$ & $(0.0227)$ & $(0.0176)$ & $(0.0523)$ & $(0.0229)$ & $(0.0209)$ \\
\hline \multirow[t]{2}{*}{ HSA: Median income } & $-0.372 * *$ & $-0.212^{* * *}$ & $-0.190^{* * *}$ & $-0.748^{* * *}$ & $-0.386^{* * *}$ & $-0.208^{* * *}$ & -0.255 & $-0.173 * *$ & $-0.166^{* * *}$ \\
\hline & $(0.157)$ & $(0.0655)$ & $(0.0552)$ & $(0.184)$ & $(0.0877)$ & $(0.0597)$ & $(0.165)$ & $(0.0696)$ & $(0.0605)$ \\
\hline \multirow[t]{2}{*}{ HSA: $\%$ Uninsured } & 1.640 & $7.719 * * *$ & $13.73^{* * *}$ & 6.367 & $8.402^{* * *}$ & $17.85^{* * *}$ & $9.767 * *$ & $9.100^{* * *}$ & $15.52 * * *$ \\
\hline & $(3.568)$ & $(1.861)$ & $(1.259)$ & $(3.931)$ & $(1.904)$ & $(1.447)$ & $(4.505)$ & $(2.539)$ & $(1.771)$ \\
\hline \multirow[t]{2}{*}{ HSA: $\%$ Privately insured } & $1.472^{* *}$ & $1.043^{* * *}$ & $0.407 *$ & 0.955 & $0.720^{* * *}$ & $0.428^{*}$ & $1.207 *$ & $0.755^{* * *}$ & $0.493^{* *}$ \\
\hline & $(0.601)$ & $(0.228)$ & $(0.208)$ & $(0.632)$ & $(0.246)$ & $(0.226)$ & $(0.630)$ & $(0.236)$ & $(0.243)$ \\
\hline \multirow[t]{2}{*}{ year: 2002} & 0.00847 & 0.0858 & 0.0360 & 0.00414 & 0.0830 & 0.0364 & -0.0326 & 0.0585 & 0.0419 \\
\hline & $(0.188)$ & $(0.0762)$ & $(0.0624)$ & $(0.186)$ & $(0.0755)$ & $(0.0600)$ & $(0.212)$ & $(0.0873)$ & $(0.0722)$ \\
\hline \multirow[t]{2}{*}{ year: 2003} & 0.265 & $0.239 * * *$ & 0.0690 & 0.251 & $0.229 * * *$ & 0.0671 & 0.239 & $0.195^{* *}$ & 0.0524 \\
\hline & $(0.186)$ & $(0.0788)$ & $(0.0645)$ & $(0.184)$ & $(0.0775)$ & $(0.0626)$ & $(0.208)$ & $(0.0918)$ & $(0.0752)$ \\
\hline \multirow[t]{2}{*}{ year: 2004} & $0.526^{* * *}$ & $0.415^{* * *}$ & 0.0723 & $0.515^{* * *}$ & $0.408^{* * *}$ & 0.0646 & $0.432 * *$ & $0.382 * * *$ & 0.0529 \\
\hline & $(0.188)$ & $(0.0801)$ & $(0.0672)$ & $(0.185)$ & $(0.0796)$ & $(0.0652)$ & $(0.211)$ & $(0.0931)$ & $(0.0793)$ \\
\hline \multirow[t]{2}{*}{ year: 2005} & $0.857^{* * *}$ & $0.527 * * *$ & $0.121 *$ & $0.837^{* * * *}$ & $0.518^{* * *}$ & $0.109 *$ & $0.727^{* * *}$ & $0.488^{* * *}$ & 0.111 \\
\hline & (0.184) & $(0.0724)$ & $(0.0640)$ & $(0.181)$ & $(0.0714)$ & $(0.0626)$ & $(0.205)$ & $(0.0825)$ & $(0.0747)$ \\
\hline year: 2006 & $1.177^{* * *}$ & $0.653^{* * *}$ & $0.185^{* * *}$ & $1.160^{* * *}$ & $0.649^{* * *}$ & $0.172^{* * *}$ & $1.052^{* * *}$ & $0.610^{* * *}$ & $0.178^{* *}$ \\
\hline & $(0.179)$ & $(0.0729)$ & $(0.0619)$ & $(0.176)$ & $(0.0714)$ & $(0.0602)$ & $(0.200)$ & $(0.0794)$ & $(0.0720)$ \\
\hline year: 2007 & $1.453^{* * *}$ & $0.771^{* * *}$ & $0.204^{* * *}$ & $1.432^{* * *}$ & $0.766^{* * *}$ & $0.186^{* * *}$ & $1.276^{* * *}$ & $0.715^{* * *}$ & $0.208^{* * * *}$ \\
\hline & $(0.176)$ & $(0.0738)$ & $(0.0598)$ & $(0.173)$ & $(0.0725)$ & $(0.0581)$ & $(0.197)$ & $(0.0824)$ & $(0.0697)$ \\
\hline year: 2008 & $1.669^{* * *}$ & $0.870^{* * *}$ & $0.239^{* * * *}$ & $1.645^{* * *}$ & $0.862^{* * *}$ & $0.223^{* * *}$ & $1.469^{* * *}$ & $0.776^{* * *}$ & $0.249^{* * *}$ \\
\hline & $(0.176)$ & $(0.0766)$ & $(0.0613)$ & $(0.173)$ & $(0.0756)$ & $(0.0594)$ & $(0.195)$ & $(0.0884)$ & $(0.0700)$ \\
\hline year: 2009 & $1.804^{* * *}$ & $0.976^{* * *}$ & $0.232^{* * * *}$ & $1.778^{* * *}$ & $0.967^{* * *}$ & $0.217^{* * *}$ & $1.557^{* * *}$ & $0.861^{* * *}$ & $0.237 * * *$ \\
\hline & $(0.178)$ & $(0.0837)$ & $(0.0634)$ & $(0.174)$ & $(0.0822)$ & $(0.0614)$ & $(0.199)$ & $(0.0971)$ & $(0.0736)$ \\
\hline year: 2010 & $2.024 * * *$ & $1.088^{* * *}$ & $0.268^{* * * *}$ & $1.979 * * *$ & $1.072^{* * *}$ & $0.244^{* * *}$ & $1.780^{* * *}$ & $0.992^{* * *}$ & $0.259^{* * *}$ \\
\hline & $(0.176)$ & $(0.0765)$ & $(0.0650)$ & $(0.174)$ & $(0.0761)$ & $(0.0629)$ & (0.199) & $(0.0882)$ & $(0.0765)$ \\
\hline year: 2011 & $2.025^{* * *}$ & $1.120 * * *$ & $0.324 * * *$ & $1.968^{* * *}$ & $1.096^{* * *}$ & $0.300^{* * *}$ & $1.692^{* * *}$ & $0.980 * * *$ & $0.324 * * *$ \\
\hline & $(0.182)$ & $(0.0862)$ & $(0.0652)$ & $(0.182)$ & $(0.0853)$ & $(0.0632)$ & $(0.208)$ & $(0.102)$ & $(0.0766)$ \\
\hline Constant & $-3.857^{*}$ & 1.324 & $-6.845^{* * *}$ & 2.060 & $4.303^{* * *}$ & $-5.496^{* * *}$ & $-6.953^{* * *}$ & -0.481 & $-5.820 * * *$ \\
\hline & $(1.996)$ & $(1.006)$ & $(0.752)$ & $(2.618)$ & $(1.340)$ & $(0.853)$ & $(2.224)$ & (1.133) & $(0.903)$ \\
\hline Observations & 3,460 & 3,457 & 3,460 & 3,460 & 3,457 & 3,460 & 2,762 & 2,759 & 2,762 \\
\hline R-squared & 0.457 & 0.612 & 0.737 & 0.487 & 0.633 & 0.755 & 0.417 & 0.523 & 0.637 \\
\hline
\end{tabular}

Notes: Heteroskedasticity-robust standard errors are reported in parentheses below the estimated coefficients. *, $* *$, and $* * *$ indicate significance at the $10 \%, 5 \%$, and $1 \%$ levels, respectively. 


\begin{tabular}{|c|c|c|c|c|c|c|}
\hline & \multicolumn{3}{|c|}{ Ln(Price per DRG unit) } & \multicolumn{3}{|c|}{ Ln(Top DRG price index) } \\
\hline & [1] & [2] & [3] & {$[1]$} & [2] & {$[3]$} \\
\hline Ln (Hosp-HHI) & $\begin{array}{c}0.579 * * * \\
(0.0342)\end{array}$ & $\begin{array}{c}0.490 * * * \\
(0.0499)\end{array}$ & $\begin{array}{c}0.383^{* * *} \\
(0.1110)\end{array}$ & $\begin{array}{c}0.584 * * * \\
(0.0351)\end{array}$ & $\begin{array}{c}0.521 * * * \\
(0.0499)\end{array}$ & $\begin{array}{c}0.457 * * * \\
(0.122)\end{array}$ \\
\hline Ln (Hosp-HHI) x For-profit & $\begin{array}{c}-0.218^{* * *} \\
(0.0569)\end{array}$ & $\begin{array}{c}-0.105 \\
(0.0649)\end{array}$ & $\begin{array}{l}0.00514 \\
(0.0103)\end{array}$ & $\begin{array}{c}-0.163 * * * \\
(0.0553)\end{array}$ & $\begin{array}{l}-0.0491 \\
(0.0639)\end{array}$ & $\begin{array}{c}0.0105 \\
(0.00958)\end{array}$ \\
\hline Ln (Hosp-HHI) x Government & $\begin{array}{c}-0.103 \\
(0.0665)\end{array}$ & $\begin{array}{c}-0.272^{* * *} \\
(0.0715)\end{array}$ & $\begin{array}{c}-0.0294 * * \\
(0.0136)\end{array}$ & $\begin{array}{l}-0.121 * \\
(0.0697)\end{array}$ & $\begin{array}{c}-0.269 * * * \\
(0.0736)\end{array}$ & $\begin{array}{c}-0.0326^{* *} \\
(0.0157)\end{array}$ \\
\hline For-profit & $\begin{array}{l}1.765^{* * *} \\
(0.4650)\end{array}$ & $\begin{array}{c}0.872 * \\
(0.5260)\end{array}$ & & $\begin{array}{c}1.329 * * * \\
(0.453)\end{array}$ & $\begin{array}{c}0.438 \\
(0.518)\end{array}$ & \\
\hline Government & $\begin{array}{c}0.681 \\
(0.5540)\end{array}$ & $\begin{array}{c}2.090 * * * \\
(0.5940)\end{array}$ & & $\begin{array}{c}0.825 \\
(0.581)\end{array}$ & $\begin{array}{c}2.046^{* * *} \\
(0.614)\end{array}$ & \\
\hline Teaching hospital & $\begin{array}{c}0.528 * * * \\
(0.0285)\end{array}$ & $\begin{array}{c}0.479 * * * \\
(0.0279)\end{array}$ & & $\begin{array}{c}0.419 * * * \\
(0.0288)\end{array}$ & $\begin{array}{c}0.386 * * * \\
(0.0287)\end{array}$ & \\
\hline Rural hospital & $\begin{array}{c}-0.0665^{* *} \\
(0.0311)\end{array}$ & $\begin{array}{c}-0.0727 * * \\
(0.0309)\end{array}$ & & $\begin{array}{l}-0.0377 \\
(0.0289)\end{array}$ & $\begin{array}{l}-0.0376 \\
(0.0284)\end{array}$ & \\
\hline Ln (HSA population) & $\begin{array}{c}0.0311^{* * *} \\
(0.0097)\end{array}$ & $\begin{array}{c}0.0467 * * * \\
(0.0097)\end{array}$ & & $\begin{array}{c}0.0252 * * * \\
(0.00882)\end{array}$ & $\begin{array}{c}0.0347 * * * \\
(0.00922)\end{array}$ & \\
\hline HSA: Median income & $\begin{array}{l}0.0536 * \\
(0.0319)\end{array}$ & $\begin{array}{c}0.0171 \\
(0.0331)\end{array}$ & & $\begin{array}{c}0.0943 * * * \\
(0.0317)\end{array}$ & $\begin{array}{c}0.0676^{* *} \\
(0.0337)\end{array}$ & \\
\hline HSA: \% Uninsured & $\begin{array}{c}-0.643 \\
(0.7570)\end{array}$ & $\begin{array}{c}-2.009 * * \\
(0.8430)\end{array}$ & & $\begin{array}{l}-0.115 \\
(0.765)\end{array}$ & $\begin{array}{l}-0.847 \\
(0.844)\end{array}$ & \\
\hline HSA: $\%$ Privately insured & $\begin{array}{c}0.646 * * * \\
(0.1250)\end{array}$ & $\begin{array}{c}0.432 * * * \\
(0.1250)\end{array}$ & & $\begin{array}{c}0.490 * * * \\
(0.122)\end{array}$ & $\begin{array}{c}0.261 * * \\
(0.125)\end{array}$ & \\
\hline year: 2002 & $\begin{array}{c}0.140 * * * \\
(0.0421)\end{array}$ & $\begin{array}{c}0.138^{* * *} \\
(0.0407)\end{array}$ & $\begin{array}{c}0.131 * * * \\
(0.0318)\end{array}$ & $\begin{array}{c}0.158 * * * \\
(0.0396)\end{array}$ & $\begin{array}{c}0.159 * * * \\
(0.0383)\end{array}$ & $\begin{array}{c}0.152^{* * *} \\
(0.0322)\end{array}$ \\
\hline year: 2003 & $\begin{array}{c}0.258^{* * * *} \\
(0.0398)\end{array}$ & $\begin{array}{c}0.253 * * * \\
(0.0383)\end{array}$ & $\begin{array}{c}0.236 * * * \\
(0.0297)\end{array}$ & $\begin{array}{c}0.285^{* * *} \\
(0.0378)\end{array}$ & $\begin{array}{c}0.282^{* * *} \\
(0.0365)\end{array}$ & $\begin{array}{c}0.270^{* * *} \\
(0.0299)\end{array}$ \\
\hline year: 2004 & $\begin{array}{c}0.445^{* * *} \\
(0.0384)\end{array}$ & $\begin{array}{c}0.436 * * * \\
(0.0369)\end{array}$ & $\begin{array}{c}0.402^{* * *} \\
(0.0289)\end{array}$ & $\begin{array}{c}0.454 * * * \\
(0.0365)\end{array}$ & $\begin{array}{c}0.446 * * * \\
(0.0352)\end{array}$ & $\begin{array}{c}0.426 * * * \\
(0.0296)\end{array}$ \\
\hline year: 2005 & $\begin{array}{c}0.484 * * * \\
(0.0395)\end{array}$ & $\begin{array}{c}0.479 * * * \\
(0.0377)\end{array}$ & $\begin{array}{c}0.439 * * * \\
(0.0292)\end{array}$ & $\begin{array}{c}0.487 * * * \\
(0.0373)\end{array}$ & $\begin{array}{c}0.482^{* * *} \\
(0.0358)\end{array}$ & $\begin{array}{c}0.458^{* * *} \\
(0.0298)\end{array}$ \\
\hline year: 2006 & $\begin{array}{c}0.536 * * * \\
(0.0398)\end{array}$ & $\begin{array}{c}0.533 * * * \\
(0.0379)\end{array}$ & $\begin{array}{c}0.498 * * * \\
(0.0293)\end{array}$ & $\begin{array}{c}0.534 * * * \\
(0.0375)\end{array}$ & $\begin{array}{c}0.530 * * * \\
(0.0358)\end{array}$ & $\begin{array}{c}0.512^{* * *} \\
(0.0290)\end{array}$ \\
\hline year: 2007 & $\begin{array}{c}0.656^{* * *} \\
(0.0391)\end{array}$ & $\begin{array}{c}0.652^{* * *} \\
(0.0369)\end{array}$ & $\begin{array}{c}0.613 * * * \\
(0.0296)\end{array}$ & $\begin{array}{c}0.510 * * * \\
(0.0371)\end{array}$ & $\begin{array}{c}0.506^{* * *} \\
(0.0351)\end{array}$ & $\begin{array}{c}0.485^{\text {*** }} \\
(0.0300)\end{array}$ \\
\hline year: 2008 & $\begin{array}{c}0.682^{* * *} \\
(0.0396)\end{array}$ & $\begin{array}{c}0.679 * * * \\
(0.0375)\end{array}$ & $\begin{array}{c}0.641 * * * \\
(0.0295)\end{array}$ & $\begin{array}{c}0.648^{* * *} \\
(0.0413)\end{array}$ & $\begin{array}{c}0.645^{* * *} \\
(0.0393)\end{array}$ & $\begin{array}{c}0.628^{* * *} \\
(0.0330)\end{array}$ \\
\hline year: 2009 & $\begin{array}{c}0.768^{* * *} \\
(0.0404)\end{array}$ & $\begin{array}{c}0.764 * * * \\
(0.0380)\end{array}$ & $\begin{array}{c}0.724 * * * \\
(0.0306)\end{array}$ & $\begin{array}{c}0.683 * * * \\
(0.0418)\end{array}$ & $\begin{array}{c}0.679 * * * \\
(0.0397)\end{array}$ & $\begin{array}{c}0.661 * * * \\
(0.0329)\end{array}$ \\
\hline year: 2010 & $\begin{array}{c}0.828 * * * \\
(0.0403)\end{array}$ & $\begin{array}{c}0.822^{* * *} \\
(0.0382)\end{array}$ & $\begin{array}{c}0.766^{* * *} \\
(0.0314)\end{array}$ & $\begin{array}{c}0.768 * * * \\
(0.0415)\end{array}$ & $\begin{array}{c}0.760 * * * \\
(0.0397)\end{array}$ & $\begin{array}{c}0.732^{* * *} \\
(0.0330)\end{array}$ \\
\hline year: 2011 & $\begin{array}{c}0.877^{* * *} \\
(0.0402)\end{array}$ & $\begin{array}{c}0.870^{* * *} \\
(0.0382)\end{array}$ & $\begin{array}{c}0.809 * * * \\
(0.0321)\end{array}$ & $\begin{array}{c}0.837 * * * \\
(0.0403)\end{array}$ & $\begin{array}{c}0.828 * * * \\
(0.0386)\end{array}$ & $\begin{array}{c}0.796^{* * *} \\
(0.0332)\end{array}$ \\
\hline Constant & $\begin{array}{c}2.723^{* * *} \\
(0.4520)\end{array}$ & $\begin{array}{c}3.772^{* * *} \\
(0.5360)\end{array}$ & $\begin{array}{l}5.548^{* * *} \\
(0.9080)\end{array}$ & $\begin{array}{c}2.541^{* * *} \\
(0.464)\end{array}$ & $\begin{array}{c}3.331 * * * \\
(0.543)\end{array}$ & $\begin{array}{c}5.106^{* * *} \\
(1.005)\end{array}$ \\
\hline Observations & 3,449 & 3,449 & 3,494 & 3,422 & 3,422 & 3,467 \\
\hline R-squared & 0.359 & 0.442 & 0.733 & 0.327 & 0.403 & 0.678 \\
\hline HRR Fixed Effects & & YES & & & YES & \\
\hline Hospital Fixed Effects & & & YES & & & YES \\
\hline
\end{tabular}

Notes: Heteroskedasticity-robust standard errors are reported in parentheses below the estimated coefficients. *, **, and $* * *$ indicate significance at the $10 \%, 5 \%$, and $1 \%$ levels, respectively. 
Table 6: Summary statistics for unprofitable service offerings

\begin{tabular}{|c|c|c|c|c|c|c|}
\hline \multirow{2}{*}{ Service } & \multicolumn{2}{|c|}{ Nonprofit } & \multicolumn{2}{|c|}{ For profit } & \multicolumn{2}{|c|}{ Government } \\
\hline & Mean & S.D. & Mean & S.D. & Mean & S.D. \\
\hline ER & $84.5 \%$ & $36.2 \%$ & $73.5 \%$ & $44.2 \%$ & $88.5 \%$ & $32.0 \%$ \\
\hline Trauma & $16.7 \%$ & $37.3 \%$ & $5.3 \%$ & $22.3 \%$ & $13.9 \%$ & $34.6 \%$ \\
\hline Psychiatric & $25.0 \%$ & $43.3 \%$ & $25.8 \%$ & $43.8 \%$ & $29.2 \%$ & $45.5 \%$ \\
\hline $\mathrm{OB}$ & $71.5 \%$ & $45.1 \%$ & $57.3 \%$ & $49.5 \%$ & $59.1 \%$ & $49.2 \%$ \\
\hline Burn ICU & $3.5 \%$ & $18.4 \%$ & $1.8 \%$ & $13.4 \%$ & $4.7 \%$ & $21.1 \%$ \\
\hline
\end{tabular}


Table 7: Probit regressions for unprofitable service offerings with HRR fixed effects

\begin{tabular}{|c|c|c|c|c|c|}
\hline & [1] & [2] & [3] & {$[4]$} & [5] \\
\hline Variables & ER & Trauma & Psychiatric & $\mathrm{OB}$ & Burn ICU \\
\hline \multirow[t]{2}{*}{ Ln (Hosp-HHI) } & 0.496 & 0.213 & $0.877^{* *}$ & $1.677 * * *$ & -0.293 \\
\hline & $(0.848)$ & $(0.637)$ & $(0.362)$ & $(0.455)$ & $(0.665)$ \\
\hline \multirow[t]{2}{*}{ Ln (Hosp-HHI) x For-profit } & 0.395 & 1.441 & -0.0361 & 0.0208 & 0.891 \\
\hline & $(0.640)$ & $(1.000)$ & $(0.565)$ & $(0.582)$ & $(0.877)$ \\
\hline \multirow[t]{2}{*}{ Ln (Hosp-HHI) x Government } & 0.216 & 0.384 & -0.362 & 0.562 & -0.225 \\
\hline & $(1.234)$ & $(0.858)$ & $(0.536)$ & $(0.663)$ & $(0.622)$ \\
\hline \multirow[t]{2}{*}{ For-profit } & -3.845 & -12.21 & 0.0933 & -0.608 & -7.270 \\
\hline & $(5.022)$ & $(8.133)$ & $(4.524)$ & $(4.569)$ & $(6.900)$ \\
\hline \multirow[t]{2}{*}{ Government } & -1.322 & -2.866 & 3.488 & -4.580 & 2.285 \\
\hline & $(10.48)$ & $(7.142)$ & (4.388) & $(5.472)$ & $(4.999)$ \\
\hline \multirow[t]{2}{*}{ Teaching hospital } & $1.205^{* * *}$ & $2.026 * * *$ & $1.493 * * *$ & 0.373 & $0.941 *$ \\
\hline & $(0.461)$ & $(0.428)$ & $(0.282)$ & $(0.253)$ & $(0.515)$ \\
\hline \multirow[t]{2}{*}{ Rural hospital } & -0.249 & & $-2.057 * * *$ & $-0.857 * *$ & \\
\hline & $(0.399)$ & & $(0.375)$ & $(0.393)$ & \\
\hline \multirow[t]{2}{*}{ Case Mix Index } & 0.277 & $0.592 * *$ & $-2.196 * * *$ & -0.297 & $0.491^{* *}$ \\
\hline & $(0.314)$ & $(0.258)$ & $(0.351)$ & $(0.216)$ & $(0.220)$ \\
\hline \multirow[t]{2}{*}{ Ln (HSA population) } & $-0.318^{* *}$ & $0.421 * * *$ & $0.214^{* *}$ & 0.126 & 0.0819 \\
\hline & $(0.126)$ & $(0.138)$ & $(0.0963)$ & $(0.101)$ & $(0.137)$ \\
\hline \multirow[t]{2}{*}{ HSA: Median income } & $0.480^{* *}$ & -0.264 & -0.133 & 0.127 & -0.898 \\
\hline & $(0.242)$ & $(0.436)$ & $(0.226)$ & $(0.354)$ & $(0.925)$ \\
\hline \multirow[t]{2}{*}{ HSA: $\%$ Uninsured } & -0.829 & 11.72 & $-14.16^{* *}$ & -2.662 & -2.829 \\
\hline & $(8.079)$ & $(11.19)$ & $(5.647)$ & $(7.090)$ & $(11.61)$ \\
\hline \multirow[t]{2}{*}{ HSA: \% Privately insured } & $-3.691 * * *$ & $3.410^{* *}$ & 1.294 & -0.462 & 3.160 \\
\hline & $(1.350)$ & $(1.373)$ & $(0.979)$ & $(1.289)$ & $(1.946)$ \\
\hline \multirow[t]{2}{*}{ year: 2002} & $12.53 * * *$ & $6.646^{* * *}$ & $6.911 * * *$ & $11.57^{* * *}$ & $5.068^{* * *}$ \\
\hline & $(0.593)$ & $(0.457)$ & $(0.217)$ & $(0.437)$ & $(0.357)$ \\
\hline \multirow[t]{2}{*}{ year: 2003} & $12.58^{* * *}$ & $6.718^{* * *}$ & $6.977 * * *$ & $11.52^{* * *}$ & $5.096^{* * *}$ \\
\hline & $(0.602)$ & $(0.444)$ & $(0.221)$ & $(0.436)$ & $(0.371)$ \\
\hline \multirow[t]{2}{*}{ year: 2004} & $12.35^{* * *}$ & $6.745^{* * *}$ & $7.022^{* * *}$ & $11.50 * * *$ & $5.062^{* * *}$ \\
\hline & $(0.556)$ & $(0.457)$ & $(0.228)$ & $(0.432)$ & $(0.374)$ \\
\hline \multirow[t]{2}{*}{ year: 2005} & $12.38^{* * *}$ & $6.779 * * *$ & $7.020^{* * *}$ & $11.54 * * *$ & $5.099 * * *$ \\
\hline & $(0.554)$ & $(0.474)$ & $(0.228)$ & $(0.438)$ & $(0.380)$ \\
\hline \multirow[t]{2}{*}{ year: 2006} & $12.66^{* * *}$ & $6.790 * * *$ & $7.001 * * *$ & $11.56^{* * *}$ & $5.106^{* * *}$ \\
\hline & $(0.559)$ & $(0.461)$ & $(0.246)$ & $(0.436)$ & $(0.376)$ \\
\hline \multirow[t]{2}{*}{ year: 2007} & $12.66^{* * *}$ & $6.815^{* * *}$ & $7.076^{* * *}$ & $11.55^{* * *}$ & $5.072^{* * *}$ \\
\hline & $(0.571)$ & $(0.473)$ & $(0.226)$ & $(0.439)$ & $(0.382)$ \\
\hline \multirow[t]{2}{*}{ year: 2008} & $12.55^{* * *}$ & $6.809 * * *$ & $7.171^{* * *}$ & $11.58^{* * *}$ & $5.068^{* * *}$ \\
\hline & $(0.610)$ & $(0.454)$ & $(0.228)$ & $(0.435)$ & $(0.369)$ \\
\hline \multirow[t]{2}{*}{ year: 2009} & $12.51^{* * *}$ & $6.815^{* * *}$ & $7.119^{* * *}$ & $11.58^{* * *}$ & $5.091^{* * *}$ \\
\hline & $(0.610)$ & $(0.444)$ & $(0.239)$ & $(0.433)$ & $(0.367)$ \\
\hline \multirow[t]{2}{*}{ year: 2010} & $12.57 * * *$ & $6.876^{* * *}$ & $7.236^{* * *}$ & $11.56^{* * *}$ & $5.272^{* * *}$ \\
\hline & $(0.577)$ & $(0.475)$ & $(0.260)$ & $(0.440)$ & $(0.375)$ \\
\hline \multirow[t]{2}{*}{ year: 2011} & $12.48^{* * *}$ & $6.893^{* * *}$ & $7.344 * * *$ & $11.56^{* * *}$ & 5.209 *** \\
\hline & $(0.554)$ & $(0.511)$ & $(0.279)$ & $(0.438)$ & $(0.405)$ \\
\hline Constant & $-14.60^{*}$ & $-14.18^{*}$ & $-13.04 * * *$ & $-26.23 * * *$ & 2.761 \\
\hline & $(8.107)$ & $(7.433)$ & (3.617) & $(6.464)$ & $(12.75)$ \\
\hline Observations & 3,450 & 2,498 & 3,118 & 3,450 & 2,004 \\
\hline
\end{tabular}

Notes: Specifications include HRR fixed effects. Heteroskedasticity-robust standard errors are reported in parentheses below the estimated coefficients. *, **, and *** indicate significance at the $10 \%, 5 \%$, and $1 \%$ levels, respectively. 
Table 8: Full covariates results, (Hosp-HHI based on all patients; hospitals in top and bottom $25 \%$ of change in Hosp-HHI)

\begin{tabular}{|c|c|c|c|c|c|c|c|c|c|}
\hline & [1] & [2] & [3] & [4] & [5] & [6] & [7] & [8] & [9] \\
\hline & \multicolumn{3}{|c|}{ Full sample } & \multicolumn{3}{|c|}{ Full sample, including HRR fixed effects } & \multicolumn{3}{|c|}{ Excluding rural hospitals } \\
\hline & Charity care & Uncomp. care & Charity volume & Charity care & Uncomp. care & Charity volume & Charity care & Uncomp. care & Charity volume \\
\hline Ln (Hosp-HHI) & $\begin{array}{c}-0.0212 \\
(0.170)\end{array}$ & $\begin{array}{c}-0.202^{* *} \\
(0.0804)\end{array}$ & $\begin{array}{c}0.448^{* * *} \\
(0.0706)\end{array}$ & $\begin{array}{l}-0.504 \\
(0.328)\end{array}$ & $\begin{array}{c}-0.507^{* * *} \\
(0.144)\end{array}$ & $\begin{array}{c}0.335^{* * *} \\
(0.118)\end{array}$ & $\begin{array}{c}0.162 \\
(0.190)\end{array}$ & $\begin{array}{c}-0.101 \\
(0.0868)\end{array}$ & $\begin{array}{c}0.401 * * * \\
(0.0874)\end{array}$ \\
\hline Ln (Hosp-HHI) x For-profit & $\begin{array}{c}0.258 \\
(0.372)\end{array}$ & $\begin{array}{c}0.642 * * * \\
(0.155)\end{array}$ & $\begin{array}{c}0.307^{* *} \\
(0.125)\end{array}$ & $\begin{array}{l}0.0169 \\
(0.441)\end{array}$ & $\begin{array}{c}0.641 * * * \\
(0.149)\end{array}$ & $\begin{array}{c}0.181 \\
(0.138)\end{array}$ & $\begin{array}{c}0.212 \\
(0.432)\end{array}$ & $\begin{array}{c}0.571 * * * \\
(0.131)\end{array}$ & $\begin{array}{c}0.399 * * * \\
(0.150)\end{array}$ \\
\hline Ln (Hosp-HHI) x Government & $\begin{array}{c}2.788^{* * *} \\
(0.563)\end{array}$ & $\begin{array}{c}0.770^{* * *} \\
(0.246)\end{array}$ & $\begin{array}{c}-1.125^{* * *} \\
(0.128)\end{array}$ & $\begin{array}{c}2.806^{* * *} \\
(0.613)\end{array}$ & $\begin{array}{c}1.004 * * * \\
(0.261)\end{array}$ & $\begin{array}{c}-1.057 * * * \\
(0.142)\end{array}$ & $\begin{array}{c}8.750^{* * *} \\
(0.673)\end{array}$ & $\begin{array}{c}2.759 * * * \\
(0.412)\end{array}$ & $\begin{array}{c}-1.685^{* * *} \\
(0.214)\end{array}$ \\
\hline For-profit & $\begin{array}{l}-2.554 \\
(3.043)\end{array}$ & $\begin{array}{c}-5.352^{* * *} \\
(1.256)\end{array}$ & $\begin{array}{c}-2.659 * * \\
(1.038)\end{array}$ & $\begin{array}{l}-0.528 \\
(3.579)\end{array}$ & $\begin{array}{c}-5.296^{* * *} \\
(1.206)\end{array}$ & $\begin{array}{l}-1.672 \\
(1.144)\end{array}$ & $\begin{array}{l}-1.770 \\
(3.520)\end{array}$ & $\begin{array}{c}-4.590^{* * *} \\
(1.075)\end{array}$ & $\begin{array}{c}-3.370^{* * *} \\
(1.232)\end{array}$ \\
\hline Government & $\begin{array}{c}-24.83^{* * *} \\
(4.750)\end{array}$ & $\begin{array}{c}-6.788^{* * *} \\
(2.094)\end{array}$ & $\begin{array}{c}9.555^{* * *} \\
(1.074)\end{array}$ & $\begin{array}{c}-25.14^{* * * *} \\
(5.151)\end{array}$ & $\begin{array}{c}-8.786^{* * *} \\
(2.204)\end{array}$ & $\begin{array}{c}8.905^{* * *} \\
(1.187)\end{array}$ & $\begin{array}{c}-74.99 * * * \\
(5.592)\end{array}$ & $\begin{array}{c}-23.47 * * * \\
(3.480)\end{array}$ & $\begin{array}{c}14.39 * * * \\
(1.791)\end{array}$ \\
\hline Teaching hospital & $\begin{array}{c}-1.282^{* * *} \\
(0.325)\end{array}$ & $\begin{array}{c}-0.473^{* *} \\
(0.208)\end{array}$ & $\begin{array}{c}0.857^{* * *} \\
(0.108)\end{array}$ & $\begin{array}{c}-1.255^{* * *} \\
(0.334)\end{array}$ & $\begin{array}{c}-0.426^{*} \\
(0.223)\end{array}$ & $\begin{array}{c}1.154 * * * \\
(0.0791)\end{array}$ & $\begin{array}{c}0.102 \\
(0.241)\end{array}$ & $\begin{array}{c}-0.0425 \\
(0.175)\end{array}$ & $\begin{array}{c}0.717 * * * \\
(0.128)\end{array}$ \\
\hline Ln (Total discharges) & $\begin{array}{l}1.584 * * * \\
(0.0738)\end{array}$ & $\begin{array}{l}1.033 * * * \\
(0.0400)\end{array}$ & $\begin{array}{c}1.149 * * * \\
(0.0217)\end{array}$ & $\begin{array}{l}1.603 * * * \\
(0.0743)\end{array}$ & $\begin{array}{l}1.018^{* * *} \\
(0.0470)\end{array}$ & $\begin{array}{l}1.182 * * * \\
(0.0249)\end{array}$ & $\begin{array}{l}1.957 * * * \\
(0.0813)\end{array}$ & $\begin{array}{l}1.229 * * * \\
(0.0550)\end{array}$ & $\begin{array}{c}1.155^{* * *} \\
(0.0300)\end{array}$ \\
\hline Rural hospital & $\begin{array}{c}0.841 * * * \\
(0.188)\end{array}$ & $\begin{array}{l}0.259 * * * \\
(0.0793)\end{array}$ & $\begin{array}{l}-0.0521 \\
(0.0480)\end{array}$ & $\begin{array}{c}1.076 * * * \\
(0.205)\end{array}$ & $\begin{array}{l}0.276 * * * \\
(0.0904)\end{array}$ & $\begin{array}{c}-0.164 * * * \\
(0.0538)\end{array}$ & & & \\
\hline Ln (HSA population) & $\begin{array}{c}-0.100 \\
(0.0682)\end{array}$ & $\begin{array}{l}-0.0510 \\
(0.0320)\end{array}$ & $\begin{array}{c}-0.104 * * * \\
(0.0197)\end{array}$ & $\begin{array}{c}-0.206^{* * *} \\
(0.0698)\end{array}$ & $\begin{array}{c}-0.101^{* * *} \\
(0.0349)\end{array}$ & $\begin{array}{c}-0.135^{* * *} \\
(0.0206)\end{array}$ & $\begin{array}{c}-0.289 * * * \\
(0.0782)\end{array}$ & $\begin{array}{c}-0.154 * * * \\
(0.0342)\end{array}$ & $\begin{array}{c}-0.131 * * * \\
(0.0269)\end{array}$ \\
\hline HSA: Median income & $\begin{array}{l}-0.258 \\
(0.223)\end{array}$ & $\begin{array}{c}-0.445^{* * *} \\
(0.128)\end{array}$ & $\begin{array}{c}0.0997 \\
(0.0825)\end{array}$ & $\begin{array}{c}-0.736^{* *} \\
(0.297)\end{array}$ & $\begin{array}{c}-0.568^{* * * *} \\
(0.208)\end{array}$ & $\begin{array}{c}0.346 * * * \\
(0.0934)\end{array}$ & $\begin{array}{c}0.270 \\
(0.227)\end{array}$ & $\begin{array}{c}-0.291 \text { ** } \\
(0.138)\end{array}$ & $\begin{array}{c}0.162^{*} \\
(0.0960)\end{array}$ \\
\hline HSA: \% Uninsured & $\begin{array}{l}10.13^{* *} \\
(4.714)\end{array}$ & $\begin{array}{c}8.141^{* * *} \\
(2.562)\end{array}$ & $\begin{array}{c}15.77^{* * *} \\
(1.604)\end{array}$ & $\begin{array}{l}13.50^{* *} \\
(5.493)\end{array}$ & $\begin{array}{c}7.697^{* * *} \\
(2.739)\end{array}$ & $\begin{array}{c}19.89 * * * \\
(1.569)\end{array}$ & $\begin{array}{c}21.08 * * * \\
(5.502)\end{array}$ & $\begin{array}{c}11.86^{* * *} \\
(3.365)\end{array}$ & $\begin{array}{c}18.96 * * * \\
(2.393)\end{array}$ \\
\hline HSA: $\%$ Privately insured & $\begin{array}{c}0.618 \\
(0.802)\end{array}$ & $\begin{array}{c}1.742^{* * *} \\
(0.348)\end{array}$ & $\begin{array}{c}-0.577^{* *} \\
(0.273)\end{array}$ & $\begin{array}{c}0.305 \\
(0.913)\end{array}$ & $\begin{array}{c}1.461^{* * *} \\
(0.466)\end{array}$ & $\begin{array}{l}-0.391 \\
(0.293)\end{array}$ & $\begin{array}{l}-0.499 \\
(0.780)\end{array}$ & $\begin{array}{c}1.164^{* * * *} \\
(0.329)\end{array}$ & $\begin{array}{l}-0.457 \\
(0.313)\end{array}$ \\
\hline year: 2002 & $\begin{array}{c}-0.0916 \\
(0.260)\end{array}$ & $\begin{array}{c}-0.0214 \\
(0.116)\end{array}$ & $\begin{array}{c}0.0686 \\
(0.0797)\end{array}$ & $\begin{array}{l}-0.0977 \\
(0.257)\end{array}$ & $\begin{array}{c}-0.0258 \\
(0.113)\end{array}$ & $\begin{array}{c}0.0726 \\
(0.0733)\end{array}$ & $\begin{array}{c}-0.0543 \\
(0.294)\end{array}$ & $\begin{array}{c}-0.0282 \\
(0.140)\end{array}$ & $\begin{array}{c}0.0693 \\
(0.0945)\end{array}$ \\
\hline year: 2003 & $\begin{array}{c}0.127 \\
(0.255)\end{array}$ & $\begin{array}{c}0.152 \\
(0.112)\end{array}$ & $\begin{array}{c}0.110 \\
(0.0821)\end{array}$ & $\begin{array}{c}0.116 \\
(0.252)\end{array}$ & $\begin{array}{c}0.151 \\
(0.109)\end{array}$ & $\begin{array}{c}0.112 \\
(0.0761)\end{array}$ & $\begin{array}{c}0.207 \\
(0.284)\end{array}$ & $\begin{array}{c}0.119 \\
(0.134)\end{array}$ & $\begin{array}{c}0.0933 \\
(0.0972)\end{array}$ \\
\hline year: 2004 & $\begin{array}{c}0.341 \\
(0.264)\end{array}$ & $\begin{array}{c}0.366^{* * *} \\
(0.113)\end{array}$ & $\begin{array}{c}0.0940 \\
(0.0897)\end{array}$ & $\begin{array}{c}0.324 \\
(0.260)\end{array}$ & $\begin{array}{c}0.368^{* * *} \\
(0.112)\end{array}$ & $\begin{array}{c}0.0857 \\
(0.0837)\end{array}$ & $\begin{array}{c}0.274 \\
(0.295)\end{array}$ & $\begin{array}{c}0.344 * * \\
(0.134)\end{array}$ & $\begin{array}{l}0.0579 \\
(0.109)\end{array}$ \\
\hline year: 2005 & $\begin{array}{c}0.767 * * * \\
(0.251)\end{array}$ & $\begin{array}{l}0.527 * * * \\
(0.0950)\end{array}$ & $\begin{array}{c}0.133 \\
(0.0825)\end{array}$ & $\begin{array}{c}0.731 * * * \\
(0.245)\end{array}$ & $\begin{array}{l}0.519 * * * \\
(0.0924)\end{array}$ & $\begin{array}{c}0.113 \\
(0.0756)\end{array}$ & $\begin{array}{c}0.724 * * * \\
(0.272)\end{array}$ & $\begin{array}{c}0.506 * * * \\
(0.108)\end{array}$ & $\begin{array}{c}0.126 \\
(0.0979)\end{array}$ \\
\hline year: 2006 & $\begin{array}{c}1.150^{* * *} \\
(0.236)\end{array}$ & $\begin{array}{c}0.647 * * * \\
(0.104)\end{array}$ & $\begin{array}{c}0.217 * * * \\
(0.0811)\end{array}$ & $\begin{array}{c}1.116^{* * *} \\
(0.231)\end{array}$ & $\begin{array}{c}0.642 * * * \\
(0.101)\end{array}$ & $\begin{array}{c}0.199 * * * \\
(0.0741)\end{array}$ & $\begin{array}{c}1.134 * * * \\
(0.256)\end{array}$ & $\begin{array}{c}0.628 * * * \\
(0.111)\end{array}$ & $\begin{array}{l}0.207^{* *} \\
(0.0969)\end{array}$ \\
\hline year: 2007 & $\begin{array}{c}1.334 * * * \\
(0.234)\end{array}$ & $\begin{array}{c}0.753^{* * *} \\
(0.0999)\end{array}$ & $\begin{array}{c}0.203^{* * *} \\
(0.0772)\end{array}$ & $\begin{array}{c}1.302^{* * *} \\
(0.230)\end{array}$ & $\begin{array}{c}0.753^{* * *} \\
(0.0988)\end{array}$ & $\begin{array}{c}0.179 * * * \\
(0.0690)\end{array}$ & $\begin{array}{c}1.315^{* * *} \\
(0.251)\end{array}$ & $\begin{array}{c}0.729 * * * \\
(0.110)\end{array}$ & $\begin{array}{l}0.199 * * \\
(0.0934)\end{array}$ \\
\hline year: 2008 & $\begin{array}{c}1.632 * * * \\
(0.234)\end{array}$ & $\begin{array}{c}0.842 * * * \\
(0.110)\end{array}$ & $\begin{array}{c}0.238^{* * *} \\
(0.0812)\end{array}$ & $\begin{array}{c}1.591 * * * \\
(0.232)\end{array}$ & $\begin{array}{c}0.839 * * * \\
(0.110)\end{array}$ & $\begin{array}{c}0.211 * * * \\
(0.0731)\end{array}$ & $\begin{array}{c}1.590^{* * *} \\
(0.250)\end{array}$ & $\begin{array}{c}0.737 * * * \\
(0.133)\end{array}$ & $\begin{array}{c}0.254 * * * \\
(0.0926)\end{array}$ \\
\hline year: 2009 & $\begin{array}{c}1.705^{* * *} \\
(0.235)\end{array}$ & $\begin{array}{c}0.955^{* * *} \\
(0.109)\end{array}$ & $\begin{array}{c}0.224 * * * \\
(0.0815)\end{array}$ & $\begin{array}{c}1.673^{* * *} \\
(0.232)\end{array}$ & $\begin{array}{c}0.952^{* * *} \\
(0.110)\end{array}$ & $\begin{array}{c}0.201 * * * \\
(0.0727)\end{array}$ & $\begin{array}{c}1.573^{* * *} \\
(0.253)\end{array}$ & $\begin{array}{c}0.840^{* * *} \\
(0.127)\end{array}$ & $\begin{array}{l}0.233^{* *} \\
(0.0949)\end{array}$ \\
\hline year: 2010 & $\begin{array}{c}1.733^{* * *} \\
(0.237)\end{array}$ & $\begin{array}{c}1.034^{* * *} \\
(0.110)\end{array}$ & $\begin{array}{c}0.284^{* * *} \\
(0.0802)\end{array}$ & $\begin{array}{c}1.683^{* * *} \\
(0.236)\end{array}$ & $\begin{array}{c}1.024^{* * *} \\
(0.112)\end{array}$ & $\begin{array}{c}0.256^{* * *} \\
(0.0729)\end{array}$ & $\begin{array}{c}1.541 * * * \\
(0.261)\end{array}$ & $\begin{array}{c}0.904^{* * *} \\
(0.130)\end{array}$ & $\begin{array}{c}0.269^{* * *} \\
(0.0958)\end{array}$ \\
\hline year: 2011 & $\begin{array}{c}1.704^{* * *} \\
(0.249)\end{array}$ & $\begin{array}{c}1.110^{* * *} \\
(0.116)\end{array}$ & $\begin{array}{c}0.333^{* * *} \\
(0.0852)\end{array}$ & $\begin{array}{c}1.646^{* * *} \\
(0.249)\end{array}$ & $\begin{array}{c}1.094^{* * *} \\
(0.121)\end{array}$ & $\begin{array}{c}0.310^{* * *} \\
(0.0782)\end{array}$ & $\begin{array}{c}1.411^{* * *} \\
(0.278)\end{array}$ & $\begin{array}{c}0.945^{* * *} \\
(0.140)\end{array}$ & $\begin{array}{c}0.317^{* * *} \\
(0.102)\end{array}$ \\
\hline Constant & $\begin{array}{l}-3.204 \\
(3.062)\end{array}$ & $\begin{array}{c}5.960^{* * *} \\
(1.837)\end{array}$ & $\begin{array}{c}-8.454^{* * *} \\
(1.096)\end{array}$ & $\begin{array}{c}6.913 \\
(4.291)\end{array}$ & $\begin{array}{c}10.60^{* * *} \\
(2.781)\end{array}$ & $\begin{array}{c}-10.21^{* * *} \\
(1.353)\end{array}$ & $\begin{array}{c}-11.46^{* * *} \\
(3.330)\end{array}$ & $\begin{array}{c}3.043 \\
(2.021)\end{array}$ & $\begin{array}{c}-8.629 * * * \\
(1.385)\end{array}$ \\
\hline Observations & 1,751 & 1,749 & 1,751 & 1,751 & 1,749 & 1,751 & 1,335 & 1,333 & 1,335 \\
\hline R-squared & 0.530 & 0.666 & 0.808 & 0.560 & 0.687 & 0.844 & 0.537 & 0.599 & 0.718 \\
\hline
\end{tabular}

Notes: Heteroskedasticity-robust standard errors are reported in parentheses below the estimated coefficients. *, ${ }^{* *}$, and $* * *$ indicate significance at the $10 \%, 5 \%$, and $1 \%$ levels, respectively. 
Table 9: Price regressions (Hosp-HHI based on all patients; hospitals in top and bottom $25 \%$ of change in Hosp-HHI)

\begin{tabular}{|c|c|c|c|c|c|c|}
\hline & \multicolumn{3}{|c|}{ Ln(Price per DRG unit) } & \multicolumn{3}{|c|}{ Ln(Top DRG price index) } \\
\hline & {$[1]$} & [2] & [3] & {$[1]$} & {$[2]$} & [3] \\
\hline \multirow[t]{2}{*}{ Ln (Hosp-HHI) } & $0.559 * * *$ & $0.457 * * *$ & $0.418^{* * *}$ & $0.548^{* * *}$ & $0.518^{* * *}$ & $0.592^{* * *}$ \\
\hline & $(0.0455)$ & $(0.0762)$ & $(0.126)$ & $(0.0470)$ & $(0.0760)$ & $(0.134)$ \\
\hline \multirow[t]{2}{*}{ Ln (Hosp-HHI) x For-profit } & $-0.233^{* * *}$ & $-0.165^{*}$ & 0.00698 & $-0.182^{* *}$ & -0.119 & -0.00839 \\
\hline & $(0.0756)$ & $(0.0929)$ & $(0.0154)$ & $(0.0753)$ & $(0.0934)$ & $(0.0147)$ \\
\hline \multirow[t]{2}{*}{ Ln (Hosp-HHI) x Government } & $-0.192^{* *}$ & $-0.286 * * *$ & -0.0342 & $-0.195^{* *}$ & $-0.350 * * *$ & $-0.0583^{* *}$ \\
\hline & $(0.0897)$ & $(0.0993)$ & $(0.0242)$ & $(0.0905)$ & $(0.0984)$ & $(0.0292)$ \\
\hline \multirow[t]{2}{*}{ For-profit } & $1.933 * * *$ & $1.386^{*}$ & & $1.534 * *$ & 1.049 & \\
\hline & $(0.625)$ & $(0.760)$ & & $(0.623)$ & $(0.764)$ & \\
\hline \multirow[t]{2}{*}{ Government } & $1.408^{*}$ & $2.192 * * *$ & & $1.462^{*}$ & $2.745^{* * *}$ & \\
\hline & $(0.742)$ & $(0.825)$ & & $(0.752)$ & $(0.820)$ & \\
\hline \multirow[t]{2}{*}{ Teaching hospital } & $0.558^{* * *}$ & $0.517 * * *$ & & $0.451^{* * *}$ & $0.404 * * *$ & \\
\hline & $(0.0459)$ & $(0.0483)$ & & $(0.0470)$ & $(0.0480)$ & \\
\hline \multirow[t]{2}{*}{ Rural hospital } & -0.0314 & -0.0468 & & 0.0222 & -0.00959 & \\
\hline & $(0.0436)$ & $(0.0414)$ & & $(0.0366)$ & $(0.0346)$ & \\
\hline \multirow[t]{2}{*}{ Ln (HSA population) } & $0.0365 * *$ & $0.0468^{* * *}$ & & $0.0405^{* * *}$ & $0.0438^{* * *}$ & \\
\hline & $(0.0152)$ & $(0.0153)$ & & $(0.0129)$ & $(0.0143)$ & \\
\hline \multirow[t]{2}{*}{ HSA: Median income } & $0.118^{* *}$ & $0.0937^{*}$ & & $0.162^{* * *}$ & $0.179 * * *$ & \\
\hline & $(0.0490)$ & $(0.0561)$ & & $(0.0494)$ & $(0.0561)$ & \\
\hline \multirow[t]{2}{*}{ HSA: $\%$ Uninsured } & -1.226 & $-3.697 * * *$ & & -0.257 & -1.661 & \\
\hline & $(0.968)$ & (1.054) & & $(1.017)$ & $(1.113)$ & \\
\hline \multirow[t]{2}{*}{ HSA: \% Privately insured } & $0.596^{* * *}$ & 0.0909 & & $0.500^{* * *}$ & -0.0909 & \\
\hline & $(0.179)$ & $(0.183)$ & & $(0.177)$ & $(0.181)$ & \\
\hline \multirow[t]{2}{*}{ year: 2002} & $0.153^{* *}$ & $0.148^{* * *}$ & $0.140 * * *$ & $0.168^{* * *}$ & $0.161 * * *$ & $0.155^{* * *}$ \\
\hline & $(0.0594)$ & $(0.0571)$ & $(0.0437)$ & $(0.0542)$ & $(0.0513)$ & $(0.0421)$ \\
\hline \multirow[t]{2}{*}{ year: 2003} & $0.230 * * *$ & $0.226^{* * *}$ & $0.214^{* * *}$ & $0.245^{* * *}$ & $0.239 * * *$ & $0.229 * * *$ \\
\hline & $(0.0568)$ & $(0.0544)$ & $(0.0420)$ & $(0.0544)$ & $(0.0513)$ & $(0.0406)$ \\
\hline \multirow[t]{2}{*}{ year: 2004} & $0.418^{* * *}$ & $0.411^{* * *}$ & $0.376^{* * *}$ & $0.416^{* * *}$ & $0.401 * * *$ & $0.387 * * *$ \\
\hline & $(0.0537)$ & $(0.0514)$ & $(0.0412)$ & $(0.0515)$ & $(0.0486)$ & $(0.0405)$ \\
\hline \multirow[t]{2}{*}{ year: 2005} & $0.434 * * *$ & $0.430^{* * *}$ & $0.389^{* * *}$ & $0.467 * * *$ & $0.456^{* * *}$ & $0.436^{* * *}$ \\
\hline & $(0.0568)$ & $(0.0536)$ & $(0.0417)$ & $(0.0534)$ & $(0.0504)$ & $(0.0414)$ \\
\hline \multirow[t]{2}{*}{ year: 2006} & $0.477 * * *$ & $0.470^{* * *}$ & $0.440^{* * *}$ & $0.488^{* * *}$ & $0.475^{* * *}$ & $0.466^{* * *}$ \\
\hline & $(0.0564)$ & $(0.0524)$ & $(0.0403)$ & $(0.0539)$ & $(0.0501)$ & $(0.0394)$ \\
\hline \multirow[t]{2}{*}{ year: 2007} & $0.607^{* * *}$ & $0.602^{* * *}$ & $0.567^{* * *}$ & $0.459 * * *$ & $0.447^{* * *}$ & $0.436^{* * *}$ \\
\hline & $(0.0558)$ & $(0.0514)$ & $(0.0405)$ & $(0.0530)$ & $(0.0486)$ & $(0.0406)$ \\
\hline \multirow[t]{2}{*}{ year: 2008} & $0.620^{* * *}$ & $0.615^{* * *}$ & $0.581 * * *$ & $0.573 * * *$ & $0.561 * * *$ & $0.555^{* * *}$ \\
\hline & $(0.0563)$ & $(0.0523)$ & $(0.0415)$ & $(0.0611)$ & $(0.0564)$ & $(0.0480)$ \\
\hline \multirow[t]{2}{*}{ year: 2009} & $0.717 * * *$ & $0.710^{* * *}$ & $0.677 * * *$ & $0.598^{* * *}$ & $0.582 * * *$ & $0.578^{* * *}$ \\
\hline & $(0.0564)$ & $(0.0530)$ & $(0.0442)$ & $(0.0598)$ & $(0.0559)$ & $(0.0467)$ \\
\hline year: 2010 & $0.770^{* * *}$ & $0.760^{* * *}$ & $0.704^{* * *}$ & $0.711^{* * *}$ & $0.689 * * *$ & $0.671^{* * *}$ \\
\hline & $(0.0564)$ & $(0.0536)$ & $(0.0450)$ & $(0.0601)$ & $(0.0573)$ & $(0.0463)$ \\
\hline year: 2011 & $0.813^{* * *}$ & $0.795^{* * *}$ & $0.734 * * *$ & $0.771 * * *$ & $0.742^{* * *}$ & $0.717^{* * *}$ \\
\hline & $(0.0580)$ & $(0.0555)$ & $(0.0466)$ & $(0.0594)$ & $(0.0566)$ & $(0.0470)$ \\
\hline Constant & $2.170^{* * *}$ & $3.404 * * *$ & $5.268^{* * *}$ & $1.935^{* * *}$ & $2.212^{* *}$ & $4.098 * * *$ \\
\hline & $(0.697)$ & $(0.902)$ & (1.032) & $(0.720)$ & $(0.904)$ & (1.106) \\
\hline Observations & 1,741 & 1,741 & 1,763 & 1,718 & 1,718 & 1,740 \\
\hline R-squared & 0.330 & 0.449 & 0.718 & 0.285 & 0.406 & 0.668 \\
\hline HRR Fixed Effects & & YES & & & YES & \\
\hline Hospital Fixed Effects & & & YES & & & YES \\
\hline
\end{tabular}

Notes: Heteroskedasticity-robust standard errors are reported in parentheses below the estimated coefficients. *, **, and *** indicate significance at the $10 \%, 5 \%$, and $1 \%$ levels, respectively. 
Table 10: Common DRGs used to construct the price index

\begin{tabular}{cccl}
\hline DRG & MDC & Category & \multicolumn{1}{c}{ Description } \\
\hline 88 & 4 & M & Chronic Obstructive Pulmonary Disease \\
89 & 4 & M & Simple Pneumonia \& Pleurisy Age $>17 \mathrm{w} \mathrm{cc}$ \\
97 & 4 & M & Bronchitis \& Asthma Age $>17$ w/o cc \\
127 & 5 & M & Heart Failure \& Shock \\
138 & 5 & M & Cardiac Arrhythmia \& Conduction Disorders w cc \\
ta & 5 & M & Cardiac Arrhythmia \& Conduction Disorders w/o cc \\
143 & 5 & M & Chest Pain \\
167 & 6 & P & Appendectomy w/o Complicated Principal Diagnoses w/o cc \\
174 & 6 & M & Gastrointestinal Hemorrhage w cc \\
182 & 6 & M & Esophagitis, Gastroenteritis \& Misc Digest Disorders Age $>17$ w cc \\
183 & 6 & M & Esophagitis, Gastroenteritis/Misc Digest Disorders Age $>17$ w/o cc \\
204 & 7 & M & Disorders of Pancreas except Malignancy \\
294 & 10 & M & Diabetes Age $>35$ \\
296 & 10 & M & Nutritional \& Misc Metabolic Disorders Age $>17$ w cc \\
320 & 11 & M & Kidney \& Urinary Tract Infections Age $>17$ w cc \\
359 & 13 & P & Uterine \& Adnexa Proc for Non-Malignancy w/o cc \\
416 & 18 & M & Septicemia Age $>17$ \\
\hline
\end{tabular}




\section{Appendix A: Welfare analysis for the case of linear demand curves}

We now present an example to illustrate how a merger of nonprofit hospitals can increase social welfare by suppressing competition. Following our analysis above, suppose that a hospital monopolist produces a single service at a total cost of $c(q)=F+c q$, and that it is able to divide the aggregate demand into two groups: rich patients (Market 1) and poor patients (Market 2). These two groups have two distinct downward-sloping demand curves for hospital services, the demand curves are known to the monopolist, and there is no opportunity for arbitrage between groups, as medical care is "non-tradable" from the patient prospective. To illustrate our point simply, we assume that under uniform pricing Market 2 is not served profitably when price is set at marginal cost. This is important for our example because when demand curves are linear, price discrimination results in lower welfare and uniform price is favored (Schmalensee, 1981). In our model however, since the poor are excluded under a uniform price, the welfare implications of price discrimination are ambiguous.

The monopolist chooses a price for each group. Let $\left\{P_{1}, P_{2}\right\}$ denote the prices in Market 1 and Market 2 respectively. Assume that the demand curve in Market $i$ is $q_{i}=a_{i}-b_{i} P_{i}$. Serving Market $i$ is profitable if $P_{i}>c$, or $a_{i}>c \cdot b_{i}$ for $i=1,2$. If this condition is violated a for-profit monopoly will not engage in price discrimination. Instead, it will choose a uniform price (i.e. set price in both markets equal to the monopoly price for rich patients). Such pricing behavior excludes poor patients from receiving services. On the other hand, a nonprofit monopoly may serve markets in which this condition is violated. By relying on other segments of the population for whom they can price above cost (Market 1), the nonprofit firm will price below cost in Market 2 without violating its non-distribution constraint, which applies to the organization as a whole.

Under the assumption that $c b_{2}-a_{2}>0$ a for-profit monopoly will always choose to exclude the poor $\left(q_{2}^{F}=0\right)$. On the other hand, a sufficient condition for a nonprofit monopoly to serve the poor is the ability to set $P_{1}$ above $c$. The monopoly will supply services to the poor even in the extreme case, where the social value of serving the poor (for every level of quantity) is lower than the social cost. As previously discussed, under these conditions, poor patients are served only if the hospital is nonprofit. However, this 
does not imply that, for example, merger to monopoly will necessarily increase welfare. The change in welfare across groups is given by:

$$
\Delta W=\left[\int_{0}^{q_{2}^{M}}\left[P_{2}(x)+\alpha-c\right] d x\right]-\left[\int_{P_{1}^{D}}^{P_{1}^{M}} q_{1}(x) d x\right]
$$

The first term is the surplus generated in Market 2 as a result of such merger to monopoly and the second term is the loss of consumer surplus in Market 1. As expected the desirability of merger (i.e. suppression of competition) increases with $\alpha$, the additional value that society places on each unit of the poor's consumption. While the nonprofit monopolist does not consider $\alpha$ when choosing the quantity of services to the poor, a greater $\alpha$ will increase the social benefits from eliminating competition. Subsequently this would raise the attractiveness of 501(c)(3) organizations as a vehicle for achieving social goals.

Following Proposition 2, the price for paying consumers chosen by the monopolist (problem (1)) is given by $P_{1}^{M}=\frac{a_{1}+c \cdot b_{1}}{2 \cdot b_{1}}$, whereas, the price chosen by the social planner (problem (2)) is given by $P_{1}^{*}=\frac{\lambda \cdot a_{1}+(1+\lambda) \cdot c \cdot b_{1}}{(1+2 \lambda) \cdot b_{1}}$. The profit condition $a_{1}>c \cdot b_{1}$ is necessary and sufficient for $P_{1}^{M}>P_{1}^{*} \cdot{ }^{1}$ Hence, as in the general case, the altruistic nonprofit monopolist overprices healthcare to the rich and overprovides services to the poor.

\footnotetext{
1 Proof: $a_{1}>c \cdot b_{1}$

$\Rightarrow a_{1} \cdot b_{1}>c \cdot b_{1}^{2} \Rightarrow a_{1} \cdot b_{1}+c \cdot b_{1}^{2}>2 \cdot c \cdot b_{1}^{2}$

$\Rightarrow a_{1} \cdot b_{1}+c \cdot b_{1}^{2}+2 \cdot \lambda \cdot\left(a_{1} \cdot b_{1}+c \cdot b_{1}^{2}\right)>2 \cdot c \cdot b_{1}^{2}+2 \cdot \lambda \cdot\left(a_{1} \cdot b_{1}+c \cdot b_{1}^{2}\right)$

$\Rightarrow\left(a_{1}+c \cdot b_{1}\right) \cdot(1+2 \cdot \lambda) \cdot b_{1}>2 \cdot b_{1} \cdot\left(\lambda \cdot a_{1}+(1+\lambda) \cdot c \cdot b_{1}\right) \Rightarrow \frac{a_{1}+c \cdot b_{1}}{2 \cdot b_{1}}>\frac{\lambda \cdot a_{1}+(1+\lambda) \cdot c \cdot b_{1}}{(1+2 \cdot \lambda) \cdot b_{1}}$

$\Rightarrow P_{1}^{M}>P_{1}^{*}$
} 
Appendix B1: Cross-sectional and fixed effects results, log-log specifications (Hosp-HHI based on Medicare patients only)

\begin{tabular}{|c|c|c|c|c|c|c|c|c|c|}
\hline & {$[1]$} & {$[2]$} & {$[3]$} & [4] & [5] & {$[6]$} & [7] & {$[8]$} & [9] \\
\hline & \multicolumn{3}{|c|}{ No ow nership interactions[A] } & \multicolumn{3}{|c|}{ Ownership interactions [A] } & \multicolumn{3}{|c|}{ Payer mix controls [B] } \\
\hline \multicolumn{10}{|l|}{$\underline{\text { Cross-Sectional }}$} \\
\hline \multirow[t]{2}{*}{ Ln(Hosp-HHI) } & $0.737 * * *$ & $0.264^{* * *}$ & $0.250^{* * *}$ & $0.291 * *$ & 0.0350 & $0.358^{* * *}$ & $0.294^{* *}$ & $0.104^{*}$ & $0.519^{* * *}$ \\
\hline & $(0.131)$ & $(0.0551)$ & $(0.0450)$ & $(0.122)$ & $(0.0564)$ & $(0.0552)$ & $(0.127)$ & $(0.0598)$ & $(0.0540)$ \\
\hline \multirow[t]{2}{*}{ Ln(Hosp-HHI) * For-Profit } & & & & -0.324 & $0.301^{* *}$ & $0.223^{*}$ & -0.302 & $0.276^{* *}$ & $0.209^{*}$ \\
\hline & & & & $(0.318)$ & $(0.137)$ & $(0.115)$ & $(0.321)$ & $(0.139)$ & $(0.111)$ \\
\hline \multirow[t]{2}{*}{ Ln(Hosp-HHI) *Government } & & & & $3.436 * * *$ & $0.970^{* * *}$ & $-1.074 * * *$ & $3.434 * * *$ & $0.874 * * *$ & $-1.294 * * *$ \\
\hline & & & & $(0.514)$ & $(0.223)$ & $(0.115)$ & $(0.520)$ & $(0.231)$ & $(0.110)$ \\
\hline Observations & 3,488 & 3,485 & 3,488 & 3,488 & 3,485 & 3,488 & 3,488 & 3,485 & 3,488 \\
\hline R-squared & 0.424 & 0.601 & 0.703 & 0.443 & 0.606 & 0.711 & 0.443 & 0.608 & 0.723 \\
\hline \multirow[t]{2}{*}{$\operatorname{Ln}($ Hosp-HHI $)$} & -0.466 & $-0.542^{* * *}$ & 0.131 & -0.579 & $-0.546^{* * *}$ & 0.102 & -0.559 & $-0.548^{* * *}$ & 0.0193 \\
\hline & $(0.618)$ & $(0.190)$ & $(0.203)$ & $(0.674)$ & $(0.195)$ & $(0.204)$ & $(0.644)$ & $(0.186)$ & $(0.169)$ \\
\hline \multirow[t]{2}{*}{ Ln(Hosp-HHI) * For-Profit } & & & & 0.0662 & -0.00893 & 0.0222 & $0.0651 *$ & -0.00884 & 0.0266 \\
\hline & & & & $(0.0391)$ & $(0.0105)$ & $(0.0164)$ & $(0.0374)$ & $(0.00963)$ & $(0.0184)$ \\
\hline \multirow[t]{2}{*}{ Ln(Hosp-HHI) *Government } & & & & 0.0976 & 0.0267 & 0.0132 & 0.0984 & 0.0267 & 0.00973 \\
\hline & & & & $(0.120)$ & $(0.0347)$ & $(0.0181)$ & $(0.121)$ & $(0.0345)$ & $(0.0150)$ \\
\hline Observations & 3,488 & 3,485 & 3,488 & 3,488 & 3,485 & 3,488 & 3,488 & 3,485 & 3,488 \\
\hline R-squared & 0.792 & 0.839 & 0.927 & 0.793 & 0.839 & 0.927 & 0.793 & 0.839 & 0.933 \\
\hline
\end{tabular}

[A] Specification also includes year dummies, For-profit and Government hospital dummies, Ln(Total Discharges)

[B] Specification also includes year dummies, For-profit and Government hospital dummies, Ln(Total Discharges), HSA \% Privately insured, HSA \% Self-pay

Notes: Heteroskedasticity-robust standard errors are reported in parentheses below the estimated coefficients. *,**, and *** indicate significance at the $10 \%, 5 \%$, and $1 \%$ levels, respectively. Errors in the hospital fixed-effect models are clustered on HRR. 


\begin{tabular}{|c|c|c|c|c|c|c|c|c|c|}
\hline & [1] & [2] & [3] & [4] & [5] & [6] & [7] & [8] & [9] \\
\hline & \multicolumn{3}{|c|}{ Full sample } & \multicolumn{3}{|c|}{ Full sample, including HRR fixed effects } & \multicolumn{3}{|c|}{ Excluding rural hospitals } \\
\hline & Charity care & Uncomp. care & Charity volume & Charity care & Uncomp. care & Charity volume & Charity care & Uncomp. care & Charity volume \\
\hline \multirow[t]{2}{*}{ Ln (Hosp-HHI) } & 0.0980 & 0.0386 & $0.524 * * *$ & -0.206 & -0.0849 & $0.261^{* * *}$ & 0.205 & $0.122^{*}$ & $0.388^{* * *}$ \\
\hline & $(0.145)$ & $(0.0639)$ & $(0.0595)$ & $(0.223)$ & $(0.102)$ & $(0.0858)$ & $(0.159)$ & $(0.0708)$ & $(0.0680)$ \\
\hline \multirow[t]{2}{*}{ Ln (Hosp-HHI) x For-profit } & -0.527 & 0.191 & 0.154 & $-0.652^{*}$ & 0.185 & $0.323^{* *}$ & -0.547 & 0.134 & $0.274^{* *}$ \\
\hline & $(0.321)$ & $(0.140)$ & $(0.114)$ & $(0.342)$ & $(0.135)$ & $(0.125)$ & $(0.350)$ & $(0.130)$ & $(0.132)$ \\
\hline \multirow[t]{2}{*}{ Ln (Hosp-HHI) x Government } & $3.514 * * *$ & $0.957 * * *$ & $-1.069 * * *$ & $3.283^{* * *}$ & $0.934 * * *$ & $-1.040 * * *$ & $7.304 * * *$ & $2.180^{* * *}$ & $-1.472^{* * *}$ \\
\hline & $(0.508)$ & $(0.211)$ & $(0.108)$ & $(0.572)$ & $(0.230)$ & $(0.121)$ & $(0.619)$ & $(0.287)$ & $(0.144)$ \\
\hline \multirow[t]{2}{*}{ For-profit } & 3.941 & -1.599 & -1.402 & $4.981 *$ & -1.528 & $-2.801 * * *$ & 4.346 & -0.996 & $-2.421 * *$ \\
\hline & $(2.652)$ & $(1.150)$ & $(0.954)$ & $(2.820)$ & $(1.115)$ & $(1.040)$ & $(2.889)$ & $(1.072)$ & $(1.093)$ \\
\hline \multirow[t]{2}{*}{ Government } & $-31.36 * * *$ & $-8.394 * * *$ & $9.505^{* * *}$ & $-29.45^{* * *}$ & $-8.210^{* * *}$ & $9.342^{* * * *}$ & $-64.06 * * *$ & $-18.90 * * *$ & $13.20^{* * *}$ \\
\hline & $(4.361)$ & $(1.818)$ & $(0.922)$ & $(4.894)$ & $(1.963)$ & $(1.032)$ & $(5.310)$ & $(2.475)$ & $(1.229)$ \\
\hline \multirow[t]{2}{*}{ Teaching hospital } & 0.0879 & 0.147 & $0.611 * * *$ & -0.204 & 0.0406 & $0.578^{* * *}$ & $0.828^{* * *}$ & $0.337 * * *$ & $0.493^{* * *}$ \\
\hline & $(0.183)$ & $(0.108)$ & $(0.0672)$ & $(0.186)$ & $(0.116)$ & $(0.0681)$ & $(0.162)$ & $(0.0943)$ & $(0.0752)$ \\
\hline \multirow[t]{2}{*}{ Ln (Total discharges) } & $1.514 * * *$ & $1.028^{* * *}$ & $1.066^{* * *}$ & $1.574 * * *$ & $1.025^{* * *}$ & $1.075^{* * *}$ & $1.776^{* * *}$ & $1.188^{* * *}$ & $1.010^{* * *}$ \\
\hline & $(0.0569)$ & $(0.0305)$ & $(0.0219)$ & $(0.0579)$ & $(0.0348)$ & $(0.0243)$ & $(0.0628)$ & $(0.0391)$ & $(0.0295)$ \\
\hline \multirow[t]{2}{*}{ Rural hospital } & $0.755^{* * *}$ & $0.261 * * *$ & $-0.206^{* * *}$ & $0.886^{* * *}$ & $0.265^{* * *}$ & $-0.264 * * *$ & & & \\
\hline & $(0.140)$ & $(0.0616)$ & $(0.0444)$ & $(0.146)$ & $(0.0633)$ & $(0.0464)$ & & & \\
\hline \multirow[t]{2}{*}{ Ln (HSA population) } & $-0.118^{* *}$ & $-0.0490 * *$ & $-0.0711^{* * *}$ & $-0.227 * * *$ & $-0.0875^{* * *}$ & $-0.0673^{* * *}$ & $-0.257 * * *$ & $-0.109 * * *$ & $-0.0801 * * *$ \\
\hline & $(0.0497)$ & $(0.0219)$ & $(0.0177)$ & $(0.0525)$ & $(0.0233)$ & $(0.0182)$ & $(0.0537)$ & $(0.0237)$ & $(0.0214)$ \\
\hline \multirow[t]{2}{*}{ HSA: Median income } & $-0.430^{* * *}$ & $-0.236^{* * *}$ & $-0.191 * * *$ & $-0.727 * * *$ & $-0.389 * * *$ & $-0.201 * * *$ & $-0.367^{* *}$ & $-0.209 * * *$ & $-0.159 * *$ \\
\hline & $(0.160)$ & $(0.0661)$ & $(0.0565)$ & $(0.187)$ & $(0.0894)$ & $(0.0613)$ & $(0.168)$ & $(0.0708)$ & $(0.0618)$ \\
\hline \multirow[t]{2}{*}{ HSA: \% Uninsured } & -0.243 & $7.026^{* * *}$ & $12.55^{* * *}$ & 6.267 & $8.361 * * *$ & $17.21 * * *$ & 6.638 & $8.158^{* * *}$ & $14.17 * * *$ \\
\hline & $(3.525)$ & $(1.840)$ & $(1.250)$ & (3.881) & $(1.887)$ & $(1.436)$ & (4.534) & $(2.520)$ & $(1.733)$ \\
\hline \multirow[t]{2}{*}{ HSA: $\%$ Privately insured } & $1.556^{* *}$ & $1.053^{* * *}$ & 0.153 & $1.167^{*}$ & $0.783^{* * *}$ & 0.277 & $1.085^{*}$ & $0.634^{* * *}$ & 0.253 \\
\hline & $(0.609)$ & $(0.235)$ & $(0.214)$ & $(0.649)$ & $(0.251)$ & $(0.234)$ & $(0.648)$ & $(0.242)$ & $(0.249)$ \\
\hline \multirow[t]{2}{*}{ year: 2002} & 0.0437 & 0.103 & 0.0408 & 0.0358 & 0.102 & 0.0392 & -0.0105 & 0.0713 & 0.0510 \\
\hline & $(0.189)$ & $(0.0767)$ & $(0.0629)$ & $(0.187)$ & $(0.0758)$ & $(0.0601)$ & $(0.214)$ & $(0.0884)$ & $(0.0724)$ \\
\hline \multirow[t]{2}{*}{ year: 2003} & 0.305 & $0.253^{* * *}$ & 0.0698 & 0.284 & $0.245^{* * *}$ & 0.0686 & 0.243 & $0.198^{* *}$ & 0.0634 \\
\hline & $(0.188)$ & $(0.0792)$ & $(0.0651)$ & $(0.185)$ & $(0.0778)$ & $(0.0627)$ & $(0.209)$ & $(0.0920)$ & $(0.0754)$ \\
\hline \multirow[t]{2}{*}{ year: 2004} & $0.552 * * *$ & $0.433^{* * *}$ & 0.0778 & $0.535^{* * *}$ & $0.427^{* * *}$ & 0.0722 & $0.426^{* *}$ & $0.386^{* * *}$ & 0.0676 \\
\hline & $(0.189)$ & $(0.0807)$ & $(0.0679)$ & $(0.186)$ & $(0.0801)$ & $(0.0656)$ & $(0.213)$ & $(0.0943)$ & $(0.0799)$ \\
\hline \multirow[t]{2}{*}{ year: 2005} & $0.884^{* * *}$ & $0.544 * * *$ & $0.122^{*}$ & $0.850^{* * *}$ & $0.533^{* * *}$ & $0.111^{*}$ & $0.713^{* * *}$ & $0.488^{* * *}$ & 0.121 \\
\hline & (0.185) & $(0.0729)$ & $(0.0649)$ & $(0.182)$ & $(0.0718)$ & $(0.0632)$ & $(0.206)$ & $(0.0836)$ & $(0.0754)$ \\
\hline year: 2006 & $1.207 * * *$ & $0.669 * * *$ & $0.187 * * *$ & $1.178^{* * *}$ & $0.662^{* * * *}$ & $0.174 * * *$ & $1.049 * * *$ & $0.610^{* * *}$ & $0.188^{* * * *}$ \\
\hline & $(0.181)$ & $(0.0734)$ & $(0.0625)$ & $(0.178)$ & $(0.0719)$ & $(0.0605)$ & $(0.204)$ & $(0.0807)$ & $(0.0723)$ \\
\hline year: 2007 & $1.489 * * *$ & $0.790^{* * * *}$ & $0.209^{* * * *}$ & $1.451^{* * *}$ & $0.781 * * *$ & $0.189^{* * * *}$ & $1.283^{* * *}$ & $0.720 * * *$ & $0.219 * * *$ \\
\hline & $(0.177)$ & $(0.0746)$ & $(0.0603)$ & $(0.175)$ & $(0.0732)$ & $(0.0584)$ & (0.199) & $(0.0837)$ & $(0.0701)$ \\
\hline year: 2008 & $1.701^{* * *}$ & $0.886^{* * *}$ & $0.242 * * *$ & $1.660^{* * *}$ & $0.876^{* * *}$ & $0.224 * * *$ & $1.474 * * *$ & $0.778^{* * *}$ & $0.258^{* * *}$ \\
\hline & $(0.177)$ & $(0.0771)$ & $(0.0618)$ & $(0.174)$ & $(0.0761)$ & $(0.0598)$ & (0.198) & $(0.0896)$ & $(0.0705)$ \\
\hline year: 2009 & $1.839 * * *$ & $0.991 * * *$ & $0.234 * * * *$ & $1.803^{* * *}$ & $0.981 * * *$ & $0.219 * * *$ & $1.566^{* * *}$ & $0.863^{* * *}$ & $0.246^{* * *}$ \\
\hline & $(0.178)$ & $(0.0843)$ & $(0.0641)$ & $(0.175)$ & $(0.0826)$ & $(0.0619)$ & $(0.201)$ & $(0.0978)$ & $(0.0742)$ \\
\hline year: 2010 & $2.060^{* * *}$ & $1.107 * * *$ & $0.273^{* * *}$ & $2.000^{* * *}$ & $1.087^{* * *}$ & $0.247 * * *$ & $1.787 * * *$ & $0.993 * * *$ & $0.270^{* * *}$ \\
\hline & $(0.178)$ & $(0.0776)$ & $(0.0658)$ & $(0.177)$ & $(0.0770)$ & $(0.0636)$ & $(0.203)$ & $(0.0897)$ & $(0.0772)$ \\
\hline year: 2011 & $2.076^{* * *}$ & $1.138^{* * *}$ & $0.322 * * *$ & $2.006^{* * *}$ & $1.112 * * *$ & $0.296^{* * *}$ & $1.712^{* * *}$ & $0.983^{* * *}$ & $0.328 * * *$ \\
\hline & $(0.184)$ & $(0.0872)$ & $(0.0661)$ & $(0.184)$ & $(0.0861)$ & $(0.0640)$ & $(0.211)$ & $(0.103)$ & $(0.0774)$ \\
\hline Constant & -1.969 & $1.809^{*}$ & $-5.886 * * *$ & $4.496^{*}$ & $5.029 * * *$ & $-3.876^{* * *}$ & $-4.116^{*}$ & 0.269 & $-4.583^{* * *}$ \\
\hline & $(2.040)$ & (1.024) & $(0.791)$ & $(2.574)$ & $(1.311)$ & $(0.887)$ & $(2.274)$ & (1.151) & $(0.926)$ \\
\hline Observations & 3,443 & 3,440 & 3,443 & 3,443 & 3,440 & 3,443 & 2,749 & 2,746 & 2,749 \\
\hline R-squared & 0.457 & 0.612 & 0.732 & 0.486 & 0.632 & 0.752 & 0.414 & 0.521 & 0.629 \\
\hline
\end{tabular}

Notes: Heteroskedasticity-robust standard errors are reported in parentheses below the estimated coefficients. *, **, and *** indicate significance at the $10 \%, 5 \%$, and $1 \%$ levels, respectively. 


\begin{tabular}{|c|c|c|c|c|c|c|}
\hline & \multicolumn{3}{|c|}{ Ln(Price per DRG unit) } & \multicolumn{3}{|c|}{ Ln(Top DRG price index) } \\
\hline & [1] & [2] & [3] & [1] & [2] & [3] \\
\hline Ln (Hosp-HHI) & $\begin{array}{c}0.640 * * * \\
(0.0375)\end{array}$ & $\begin{array}{c}0.543^{* * *} \\
(0.0498)\end{array}$ & $\begin{array}{c}0.426^{* * *} \\
(0.102)\end{array}$ & $\begin{array}{c}0.649 * * * \\
(0.0385)\end{array}$ & $\begin{array}{c}0.568^{* * *} \\
(0.0501)\end{array}$ & $\begin{array}{c}0.415^{* * *} \\
(0.113)\end{array}$ \\
\hline Ln (Hosp-HHI) x For-profit & $\begin{array}{c}-0.236 * * * \\
(0.0617)\end{array}$ & $\begin{array}{c}-0.107 \\
(0.0684)\end{array}$ & $\begin{array}{l}0.00353 \\
(0.0101)\end{array}$ & $\begin{array}{c}-0.180 * * * \\
(0.0598)\end{array}$ & $\begin{array}{l}-0.0527 \\
(0.0669)\end{array}$ & $\begin{array}{c}0.00876 \\
(0.00937)\end{array}$ \\
\hline Ln (Hosp-HHI) x Government & $\begin{array}{l}-0.0626 \\
(0.0763)\end{array}$ & $\begin{array}{c}-0.255^{* * *} \\
(0.0757)\end{array}$ & $\begin{array}{c}-0.0297 * * \\
(0.0131)\end{array}$ & $\begin{array}{c}-0.144^{*} \\
(0.0765)\end{array}$ & $\begin{array}{c}-0.326^{* * *} \\
(0.0760)\end{array}$ & $\begin{array}{c}-0.0333^{* *} \\
(0.0149)\end{array}$ \\
\hline For-profit & $\begin{array}{c}1.973 * * * \\
(0.516)\end{array}$ & $\begin{array}{c}0.929 \\
(0.569)\end{array}$ & & $\begin{array}{c}1.521^{* * *} \\
(0.500)\end{array}$ & $\begin{array}{c}0.498 \\
(0.555)\end{array}$ & \\
\hline Government & $\begin{array}{c}0.358 \\
(0.651)\end{array}$ & $\begin{array}{c}1.996^{* * *} \\
(0.645)\end{array}$ & & $\begin{array}{c}1.044 \\
(0.650)\end{array}$ & $\begin{array}{c}2.569 * * * \\
(0.647)\end{array}$ & \\
\hline Teaching hospital & $\begin{array}{c}0.565^{* * *} \\
(0.0288)\end{array}$ & $\begin{array}{c}0.498 * * * \\
(0.0287)\end{array}$ & & $\begin{array}{c}0.450 * * * \\
(0.0286)\end{array}$ & $\begin{array}{c}0.397 * * * \\
(0.0290)\end{array}$ & \\
\hline Rural hospital & $\begin{array}{l}-0.0362 \\
(0.0307)\end{array}$ & $\begin{array}{c}-0.0565^{*} \\
(0.0307)\end{array}$ & & $\begin{array}{l}-0.0128 \\
(0.0291)\end{array}$ & $\begin{array}{l}-0.0271 \\
(0.0286)\end{array}$ & \\
\hline Ln (HSA population) & $\begin{array}{c}0.0419 * * * \\
(0.00950)\end{array}$ & $\begin{array}{c}0.0556^{* * *} \\
(0.00965)\end{array}$ & & $\begin{array}{c}0.0342^{* * *} \\
(0.00896)\end{array}$ & $\begin{array}{c}0.0421^{* * *} \\
(0.00934)\end{array}$ & \\
\hline HSA: Median income & $\begin{array}{c}0.0318 \\
(0.0325)\end{array}$ & $\begin{array}{c}-0.00203 \\
(0.0336)\end{array}$ & & $\begin{array}{c}0.0661 * * \\
(0.0324)\end{array}$ & $\begin{array}{c}0.0418 \\
(0.0344)\end{array}$ & \\
\hline HSA: $\%$ Uninsured & $\begin{array}{c}-1.483^{* *} \\
(0.752)\end{array}$ & $\begin{array}{c}-2.372^{* * *} \\
(0.838)\end{array}$ & & $\begin{array}{l}-0.915 \\
(0.764)\end{array}$ & $\begin{array}{l}-1.173 \\
(0.837)\end{array}$ & \\
\hline HSA: $\%$ Privately insured & $\begin{array}{c}0.428 * * * \\
(0.127)\end{array}$ & $\begin{array}{c}0.320 * * \\
(0.126)\end{array}$ & & $\begin{array}{c}0.282^{* *} \\
(0.125)\end{array}$ & $\begin{array}{c}0.156 \\
(0.128)\end{array}$ & \\
\hline year: 2002 & $\begin{array}{c}0.143^{* * *} \\
(0.0424)\end{array}$ & $\begin{array}{c}0.144 * * * \\
(0.0408)\end{array}$ & $\begin{array}{c}0.130 * * * \\
(0.0319)\end{array}$ & $\begin{array}{c}0.163^{* * *} \\
(0.0399)\end{array}$ & $\begin{array}{c}0.166^{* * *} \\
(0.0385)\end{array}$ & $\begin{array}{c}0.154 * * * \\
(0.0326)\end{array}$ \\
\hline year: 2003 & $\begin{array}{c}0.255^{* * *} \\
(0.0400)\end{array}$ & $\begin{array}{c}0.252^{* * *} \\
(0.0385)\end{array}$ & $\begin{array}{c}0.231 \text { *** } \\
(0.0299)\end{array}$ & $\begin{array}{c}0.282^{* * *} \\
(0.0380)\end{array}$ & $\begin{array}{c}0.281 * * * \\
(0.0367)\end{array}$ & $\begin{array}{c}0.266^{* * *} \\
(0.0301)\end{array}$ \\
\hline year: 2004 & $\begin{array}{c}0.439 * * * \\
(0.0387)\end{array}$ & $\begin{array}{c}0.435^{* * *} \\
(0.0372)\end{array}$ & $\begin{array}{c}0.397 * * * \\
(0.0290)\end{array}$ & $\begin{array}{c}0.449 * * * \\
(0.0367)\end{array}$ & $\begin{array}{c}0.445^{* * *} \\
(0.0354)\end{array}$ & $\begin{array}{c}0.423^{* * *} \\
(0.0298)\end{array}$ \\
\hline year: 2005 & $\begin{array}{c}0.478 * * * \\
(0.0396)\end{array}$ & $\begin{array}{c}0.476 * * * \\
(0.0378)\end{array}$ & $\begin{array}{c}0.432^{* * *} \\
(0.0293)\end{array}$ & $\begin{array}{c}0.482^{* * *} \\
(0.0376)\end{array}$ & $\begin{array}{c}0.478^{* * *} \\
(0.0359)\end{array}$ & $\begin{array}{c}0.453 * * * \\
(0.0301)\end{array}$ \\
\hline year: 2006 & $\begin{array}{c}0.531 * * * \\
(0.0401)\end{array}$ & $\begin{array}{c}0.531 * * * \\
(0.0381)\end{array}$ & $\begin{array}{c}0.492 * * * \\
(0.0294)\end{array}$ & $\begin{array}{c}0.528^{* * *} \\
(0.0377)\end{array}$ & $\begin{array}{c}0.526^{* * *} \\
(0.0359)\end{array}$ & $\begin{array}{c}0.506^{* * *} \\
(0.0293)\end{array}$ \\
\hline year: 2007 & $\begin{array}{c}0.652^{* * *} \\
(0.0393)\end{array}$ & $\begin{array}{c}0.650 * * * \\
(0.0371)\end{array}$ & $\begin{array}{c}0.607 * * * \\
(0.0297)\end{array}$ & $\begin{array}{c}0.507 * * * \\
(0.0374)\end{array}$ & $\begin{array}{c}0.505^{* * *} \\
(0.0354)\end{array}$ & $\begin{array}{c}0.481 \text { *** } \\
(0.0303)\end{array}$ \\
\hline year: 2008 & $\begin{array}{c}0.679 * * * \\
(0.0399)\end{array}$ & $\begin{array}{c}0.679 * * * \\
(0.0378)\end{array}$ & $\begin{array}{c}0.635^{* * *} \\
(0.0297)\end{array}$ & $\begin{array}{c}0.646^{* * *} \\
(0.0416)\end{array}$ & $\begin{array}{c}0.644 * * * \\
(0.0397)\end{array}$ & $\begin{array}{c}0.623^{* * *} \\
(0.0335)\end{array}$ \\
\hline year: 2009 & $\begin{array}{c}0.762^{* * *} \\
(0.0406)\end{array}$ & $\begin{array}{c}0.761 * * * \\
(0.0382)\end{array}$ & $\begin{array}{c}0.719^{* * *} \\
(0.0308)\end{array}$ & $\begin{array}{c}0.679 * * * \\
(0.0422)\end{array}$ & $\begin{array}{c}0.677 * * * \\
(0.0401)\end{array}$ & $\begin{array}{c}0.657^{* * *} \\
(0.0334)\end{array}$ \\
\hline year: 2010 & $\begin{array}{c}0.824 * * * \\
(0.0407)\end{array}$ & $\begin{array}{c}0.822^{* * *} \\
(0.0385)\end{array}$ & $\begin{array}{c}0.764^{* * *} \\
(0.0316)\end{array}$ & $\begin{array}{c}0.767^{* * *} \\
(0.0419)\end{array}$ & $\begin{array}{c}0.762^{* * *} \\
(0.0400)\end{array}$ & $\begin{array}{c}0.732^{* * *} \\
(0.0333)\end{array}$ \\
\hline year: 2011 & $\begin{array}{c}0.870 * * * \\
(0.0407)\end{array}$ & $\begin{array}{c}0.866^{* * *} \\
(0.0386)\end{array}$ & $\begin{array}{c}0.804^{* * *} \\
(0.0323)\end{array}$ & $\begin{array}{c}0.833^{* * *} \\
(0.0409)\end{array}$ & $\begin{array}{c}0.826^{* * *} \\
(0.0391)\end{array}$ & $\begin{array}{c}0.794 * * * \\
(0.0337)\end{array}$ \\
\hline Constant & $\begin{array}{c}2.299 * * * \\
(0.467)\end{array}$ & $\begin{array}{c}3.380 * * * \\
(0.525)\end{array}$ & $\begin{array}{c}5.132^{* * *} \\
(0.850)\end{array}$ & $\begin{array}{c}2.169 * * * \\
(0.485)\end{array}$ & $\begin{array}{c}3.076^{* * *} \\
(0.541)\end{array}$ & $\begin{array}{c}5.388^{* * *} \\
(0.945)\end{array}$ \\
\hline Observations & 3,433 & 3,433 & 3,478 & 3,407 & 3,407 & 3,452 \\
\hline R-squared & 0.363 & 0.446 & 0.735 & 0.331 & 0.408 & 0.679 \\
\hline $\begin{array}{l}\text { HRR Fixed Effects } \\
\text { Hospital Fixed Effects }\end{array}$ & & YES & YES & & YES & YES \\
\hline
\end{tabular}

Notes: Heteroskedasticity-robust standard errors are reported in parentheses below the estimated coefficients. *, **, and *** indicate significance at the $10 \%, 5 \%$, and $1 \%$ levels, respectively. 


\section{Appendix C: Construction of price measures}

Both price measures analyzed in this paper are constructed using information on hospitals' actual revenue from private payers as a percentage of their total list charges to private payers. The percentages are derived from the OSHPD financial disclosure reports, which provide gross and net inpatient revenue from third party payers, separately for "traditional” insurance products (i.e., fee-for-service plans) and managed care insurance products. Individual patient records in the hospital discharge data identify (1) the list charges associated with the visit, (2) the payer category (private, Medicare, Medicaid, etc.), and (3) whether the plan type is traditional or managed care. This facilitates matching the plan type discount factor to the patient's plan type.

The steps in computing the two price measures are as follows. We first compute the hospital-level ratio of net revenue to gross revenue in each year, separately for private traditional products and private managed care products. We exclude data from Kaiser hospitals because they do not report financial data and generally do not treat non-Kaiser patients. For each type of products, we then clean the resulting ratios by bottom-capping them at annual $5^{\text {th }}$ percentile, and top-capping them at annual $95^{\text {th }}$ percentile of ratios across hospitals.

We estimate the net payment to hospitals as the weighted average of charges by payer category and plan type. The charges are from the patient-level discharge data and we weight them using ratios obtained from the previous step.

Finally, we construct two price measures: an overall severity-adjusted price, and a price index based on conditions (DRGs) treated at a broad set of hospitals. The severityadjusted price is computed as the ratio of the total net payment to the total DRG units ${ }^{\mathrm{c} 1}$ at hospital-year level. The price index is the within DRG net payment averaged across

\footnotetext{
${ }^{c 1}$ DRG units are the case weights attached to DRGs; these weights indicate the national average relative cost of care. For example, a patient in a DRG with a weight of 4 is twice as costly to treat on average as a patient in a DRG with a weight of 2.
} 
hospitals. For the small number of hospital-years with some missing DRGs, we impute the missing index using the full sample averages. ${ }^{\mathrm{c} 2}$

Table C1 lists the DRGs used in constructing the price index. As shown in Figure C1, the two price measures are highly correlated and have similar magnitudes.

Table C1: Common DRGs used to construct the price index

\begin{tabular}{|c|c|c|c|}
\hline DRG & MDC & Category & Description \\
\hline 88 & 4 & $\mathrm{M}$ & Chronic Obstructive Fulmonary Disease \\
\hline 89 & 4 & $\mathrm{M}$ & Simple Pneumonia \& Pleurisy Age $>17 \mathrm{w} c \mathrm{cc}$ \\
\hline 97 & 4 & $\mathrm{M}$ & Bronchitis \& Asthma Age $>17 \mathrm{w} / \mathrm{o} \mathrm{cc}$ \\
\hline 127 & 5 & $\mathrm{M}$ & Heart Failure \& Shock \\
\hline 138 & 5 & $\mathrm{M}$ & Cardiac Artrythmia \& Conduction Disorders w cc \\
\hline ta & 5 & $\mathrm{M}$ & Cardiac Arrtythmia \& Conduction Disorders w/o cc \\
\hline 143 & 5 & $\mathrm{M}$ & Chest Pain \\
\hline 167 & 6 & $\mathrm{P}$ & Appendectomy $\mathrm{w} / \mathrm{o}$ Complicated Principal Diagnoses $\mathrm{w} / \mathrm{o} \mathrm{cc}$ \\
\hline 174 & 6 & $\mathrm{M}$ & Gastrointestinal Hemorthage w cc \\
\hline 182 & 6 & $\mathrm{M}$ & Esophagitis, Gastroenteritis \& Misc Digest Disorders Age $>17 \mathrm{w}$ cc \\
\hline 183 & 6 & $\mathrm{M}$ & Esophagitis, Gastroenteritis/Misc Digest Disorders Age $>17 \mathrm{w} / \mathrm{occ}$ \\
\hline 204 & 7 & $\mathrm{M}$ & Disorders of Pancreas except Malignancy \\
\hline 294 & 10 & M & Diabetes Age $>35$ \\
\hline 296 & 10 & $\mathrm{M}$ & Nutritional \& Misc Metabolic Disorders Age $>17 \mathrm{w} c \mathrm{cc}$ \\
\hline 320 & 11 & $\mathrm{M}$ & Kidney \& Uninary Tract Infections Age $>17 \mathrm{w} \mathrm{cc}$ \\
\hline 359 & 13 & $\mathrm{P}$ & Uterine \& Adnexa Proc for Non-Malignancy w/o cc \\
\hline 416 & 18 & M & Septicemia Age $>17$ \\
\hline
\end{tabular}

\section{Figure C1: Scatter plot of the two price measures}

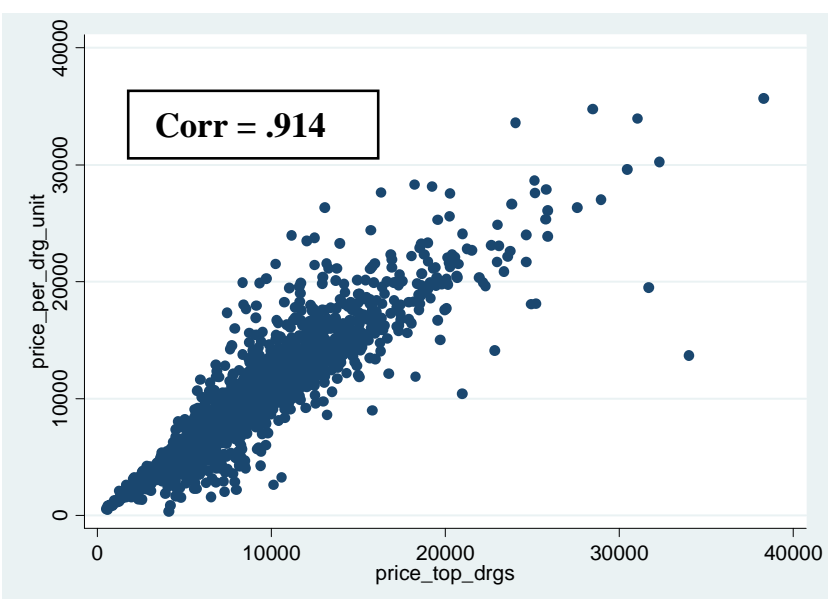

\footnotetext{
${ }^{\mathrm{c} 2}$ It would likely be possible to obtain a better price index by regressing each component price in the index on the other prices and the severity-adjusted price.
} 